\title{
CHEMICAL BUDGETS AND STREAM-CHEMISTRY DYNAMICS OF A HEADWATER STREAM IN THE CATSKILL MOUNTAINS OF NEW YORK, 1984-85 OCTOBER 1, 1983 THROUGH SEPTEMBER 30, 1985
}

By Peter S. Murdoch

U.S. GEOLOGICAL SURVEY

Water Resources Investigations Report 88-4035

Prepared in Cooperation with

U.S. ENVIRONMENTAL PROTECTION AGENCY

Albany, New York 


\section{DEPARTMENT OF THE INTERIOR \\ MANUEL LUJAN, JR., Secretary}

\section{U.S. GEOLOGICAL SURVEY}

Dallas L. Peck, Director

For additional information write to:

U.S. Geological Survey

P.O. Box 1669

Albany, NY 12201

(518) 472-3107
Copies of this report may be purchased from:

U.S. Geological Survey Books and Open-File Reports Federal Center Box 25425

Denver, CO 80225 


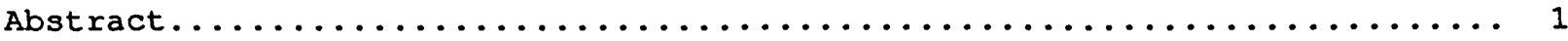

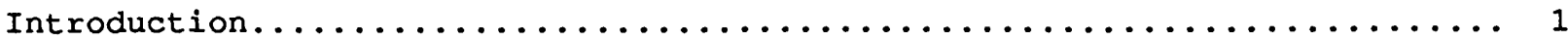

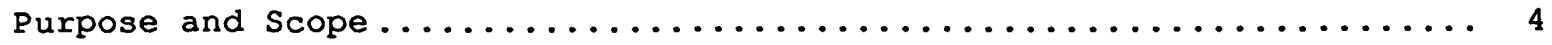

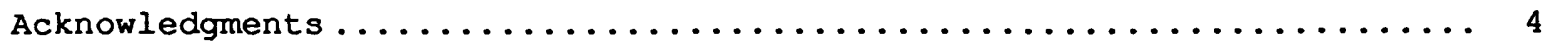

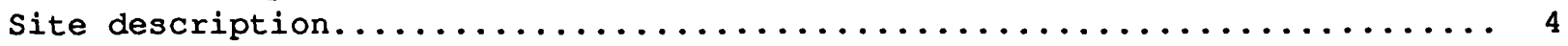

Methods.................................... 6

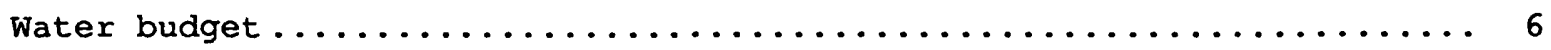

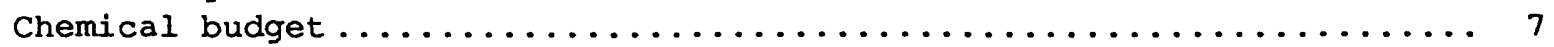

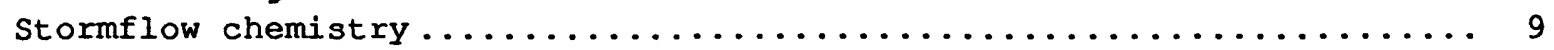

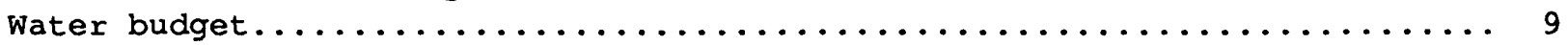

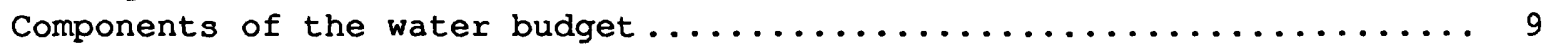

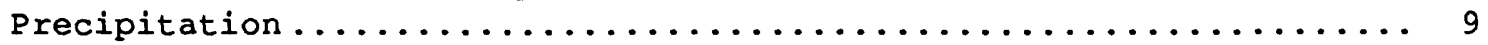

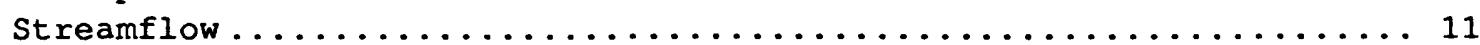

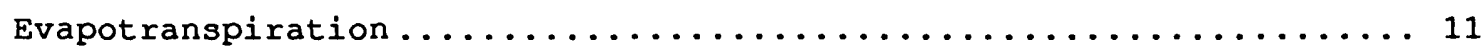

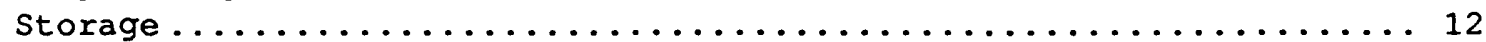

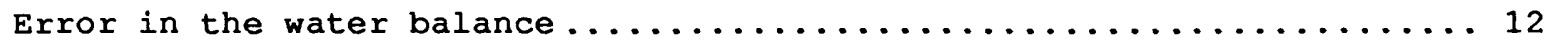

Comparison with water budgets for other parts of the Northeast...... 12

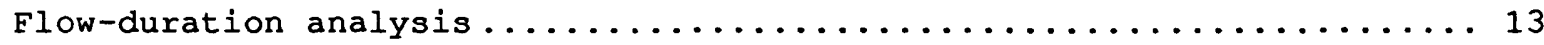

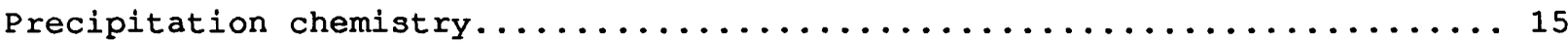

Ion concentrations and deposition rates .................. 15

Comparison with other monitoring stations in the Northeast ........ 16

Stream chemistry .................................... 17

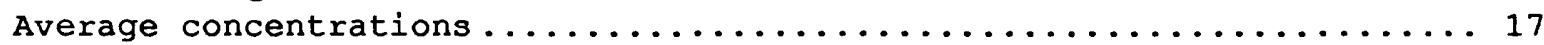

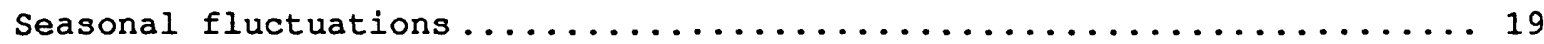

Comparison with other streams in the Catskills ............... 20

Comparison with surface waters outside the Catskills ........... 20

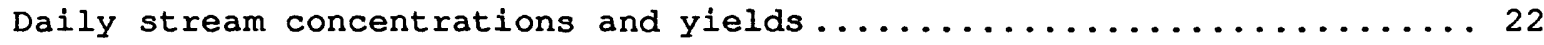

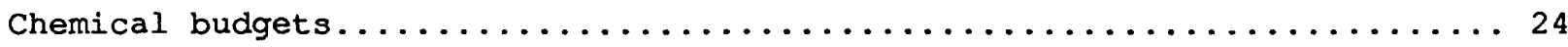

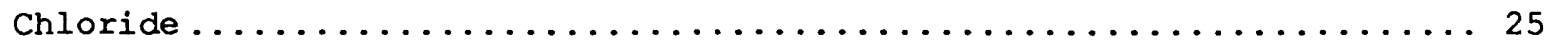

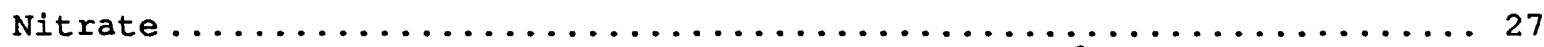

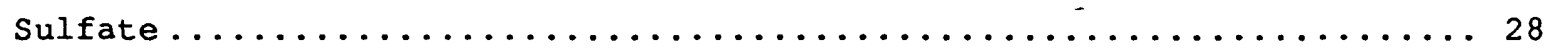

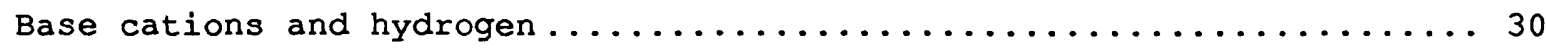

Changes in stream chemistry during storms..................... 31

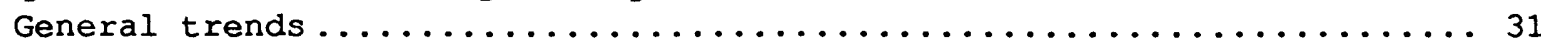

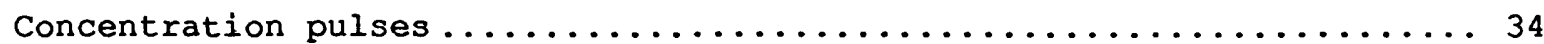

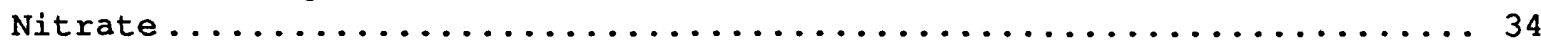

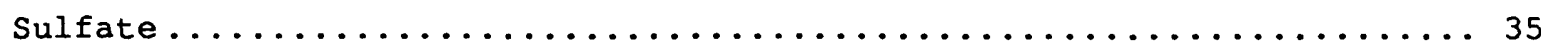

Stream acidification and aluminum mobility ................ 35

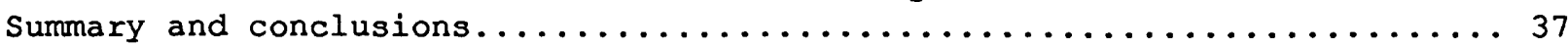

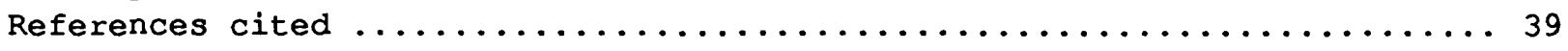

\section{ILLUSTRATIONS}

Figure 1. Map showing location of Catskill Mountain region and of Biscuit Brook watershed and watershed-monitoring stations, Ulster

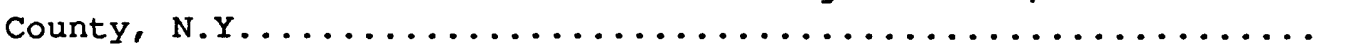




\section{ILLUSTRATIONS (continued)}

Figure 2. Bar graph of monthly discharges, evapotranspiration, and precipitation at Biscuit Brook watershed, October 1983 through

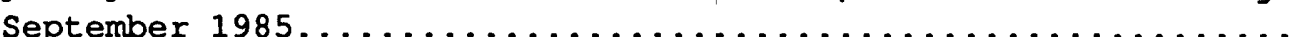

3. Daily discharge hydrographs of Biscuit Brook, water years

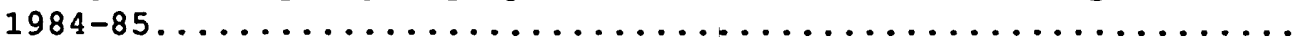

4. Flow-duration curves for Neversink River near Claryville, water years 1953-85, and Biscuit Brook, water years 1984-85... 14

5. Bar graph of seasonal concentrations of chemical constituents of precipitation at Biscuit Brook, water years 1984-1985..... 16

6. Bar graph of average concentrations of dissolved constituents in water from Biscuit Brook, N.Y., Hubbard Brook, N.H., and in Catskill region precipitation.................. 19

7. Map showing locations of stream basins studied, 1983-85..... 22

8. Graph showing cumulative yield of hitrate in Biscuit Brook, water year 1985, computed by regression and graphic

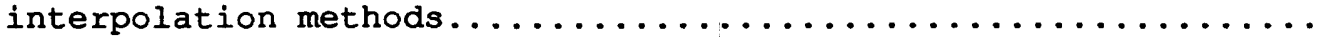

9. Bar graph of chemical inputs (deposition) from precipitation and outputs (yield) in stream water at Biscuit Brook, water

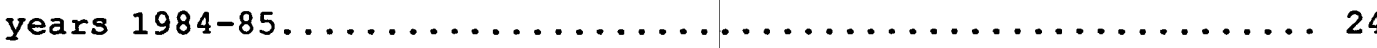

10. Graph showing nitrate concentrations in Biscuit Brook,

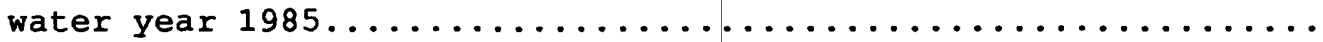

11. Graph showing differences between sulfate input (wet deposition) and output (stream yield) in the Biscuit Brook

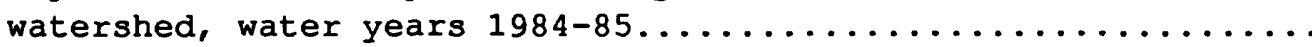

12. Graphs showing cumulative yield of total base cations and hydrogen ion in the Biscuit Brook watershed, water

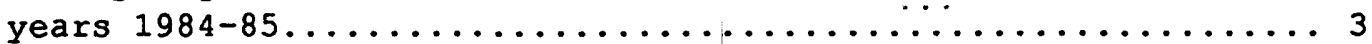

13. Graphs showing response of alkalinity, total base cations, sulfate, and nitrate concentrations to discharge of Biscuit Brook during selected high flows.................. 33

14. Graphs showing $\mathrm{pH}$ and alkalinity as a function of the log of discharge at Biscuit Brook, water years 1984-85........ 35

15. Graph showing aluminum concentrations as a function of $\mathrm{pH}$ at Biscuit Brook, water years $1984-85 \ldots \ldots \ldots \ldots \ldots \ldots \ldots . \ldots \ldots$

16. Graph showing acidic cation concentrations as a function of the ratio of anion to base-cation concentrations in Biscuit

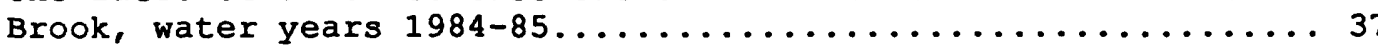




\section{ILLUSTRATIONS (continued)}

Page

Figure D-1. Graphs of stream- and precipitation-chemistry data used in assessing data quality:....................... 59

A. Calculated specific conductance in relation to measured specific conductance in stream samples

B. Anion concentration in relation to cation concentration in stream samples

C. Field specific conductance in relation to field $\mathrm{pH}$ in precipitation samples

D. Calculated specific conductance in relation to measured specific conductance in precipitation samples

E. Anion concentration in relation to cation concentration in precipitation samples

\section{TABLES}

Table 1. Hydrologic characteristics of the Biscuit Brook watershed..... 4

2. Monthly water-balance estimates for water years 1984 and 1985 at Biscuit Brook............................. 10

3. Annual precipitation at Biscuit Brook and at other measurement stations in New York...................... 13

4. Average $\mathrm{pH}$ and concentration of dissolved constituents in weekly precipitation samples from Biscuit Brook and other monitoring stations in the northeastern United States......... 15

5. Mean flow-weighted concentrations of major constituents in Biscuit Brook, seven nearby streams, and Hubbard Brook, N.H.... 18

6. Coefficients for the equations relating dissolved constituent concentration to stream discharge at Biscuit Brook, April 1983 through September $1985 \ldots \ldots \ldots \ldots \ldots \ldots \ldots . \ldots 21$

7. Comparison of annual nitrate, chloride, and potassium yields based on daily concentrations calculated through graphic interpolation and regression analysis of water year 1985

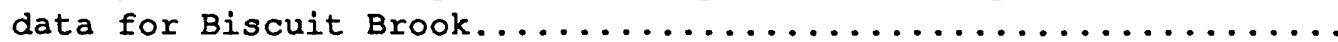

8. Annual chemical inputs in precipitation, chemical outputs in stream water, anion-to-cation ratios in stream water, and input-to-output ratios for Biscuit Brook, water years 1984-85. 


\section{TABLES (CONTINUED)}

Table 9. Selected precipitation, watershed, and stream characteristics during 14 high-flow periods at Biscuit Brook,

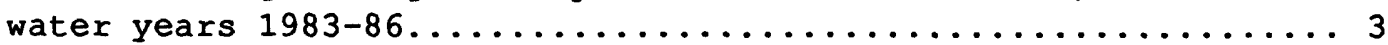

D-1. Concentrations of major chemical constituents in blind audit samples received by the U.S. Geologic Survey, October 1984

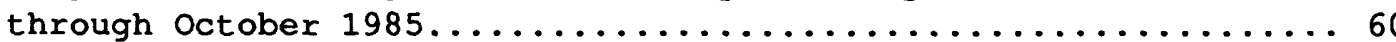

D-2. Concentrations of major chemical cohstituents in duplicate stream samples taken in Catskill streams, April 1983 through

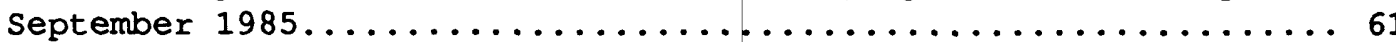

D-3. Concentrations of minor chemical constituents in duplicate samples taken in Catskill streams, April 1983 through

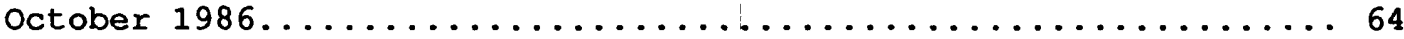

D-4. Effect of storage time on field alkalinity and field pH

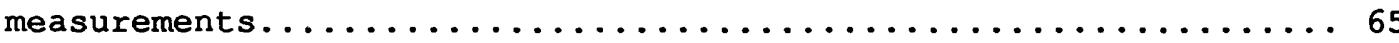

D-5. Comparison of $\mathrm{pH}$ and alkalinity measurements on raw and filtered high-flow samples containing suspended sediment...... 66

D-6. Comparison of measured concentrations of major constituents and metals passed through $0.1-, 0.2-$, and 0.4 -micrometer

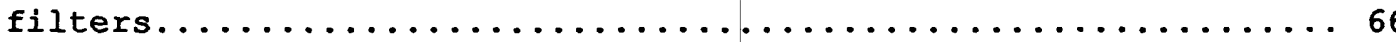

\section{APPENDIXES}

A. Concentrations of major constituents of Biscuit Brook water samples, April 1983 through September $1985 \ldots \ldots \ldots \ldots \ldots \ldots \ldots \ldots \ldots$

B. Concentrations of minor constituents of Biscuit Brook water samples, April 1983 through September $1985 \ldots \ldots \ldots \ldots \ldots \ldots \ldots \ldots \ldots \ldots$

C. Concentrations of major constituents of weekly precipitation samples from the National Trends Network monitoring station at Biscuit Brook, October 1983 through September $1985 \ldots \ldots \ldots \ldots \ldots \ldots 4$

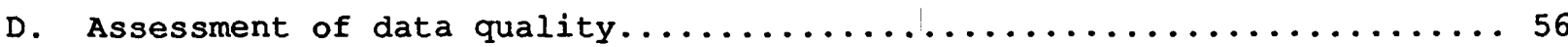

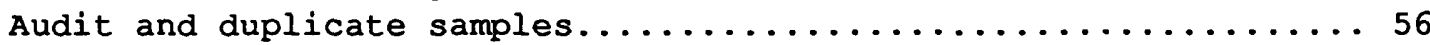

Field measurements............................. 56

Laboratory measurements........................ 57

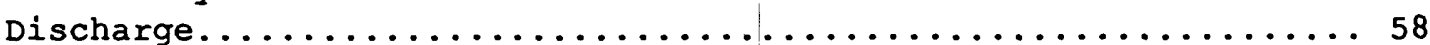

Precipitation volume and chemistry.................. 58 


\section{CONVERSION FACTORS AND ABBREVIATIONS}

The following factors may be used to convert metric (International system) units of measurements used in this report to inch-pound units.

Multiply metric units

centimeter $(\mathrm{cm})$

meter (m)

kilometer $(\mathrm{km})$

square kilometer $\left(\mathrm{km}^{2}\right)$

liter $(L)$

milliliter (mL)

cubic meter per second $\left(\mathrm{m}^{3} / \mathrm{s}\right)$

degree Celsius $\left({ }^{\circ} \mathrm{C}\right)$

hectare (ha) by

0.3937

3.281

0.621

0.3861

0.2642

0.0338

35.31

$\left(1.8 \times{ }^{\circ} \mathrm{C}\right)+32$

2.471
To obtain inch-pound units

inch (in.)

foot (ft)

mile (mi)

square mile (mi)

gallon (gal)

fluid ounce (oz)

cubic foot per second ( $\mathrm{ft}^{3} / \mathrm{s}$ )

degree Fahrenheit $\left({ }^{\circ} \mathrm{F}\right)$

acre

\section{Other Abbreviations}

microsiemens per centimeter at $25^{\circ} \mathrm{C}(\mu \mathrm{s} / \mathrm{cm})$

microequivalents per liter $(\mu \mathrm{eq} / \mathrm{L})$

milliequivalents per liter $(\mu e q / L)$

milligrams per liter (mg/L)

Water Year

The 365-day period from october 1 through

September 30 of the following year. 


\title{
CHEMICAL BUDGETS AND STREAM-CHEMISTRY DYNAMICS OF A
}

\section{HEADWATER STREAM IN THE CATSKILL MOUNTAINS, NEW YORK, 1984-85}

\author{
By Peter S. Murdoch
}

\begin{abstract}
Chemical quality of precipitation and stream water were measured weekly and during nine storm and five snowmelt-related high flows at Biscuit Brook, a headwater stream in the Catskill Mountains. Correlations between individual constituent concentrations and streamflow were significant (99-percent confidence level) for all major constituents except potassium, nitrate, and ammonium, which are assumed to have been affected by biological activity. Chemical budgets for major constituents indicate a net loss of all but hydrogen ion, nitrate, and ammonium from the basin. If dryfall deposition is assumed to equal 30 percent of wetfall, the atmospheric input of sulfate and chloride balances stream output of these constituents, but a net retention of nitrate in the watershed is indicated.
\end{abstract}

Changes in stream-water quality during storms were consistent with changes predicted by an equation relating chemical concentrations to discharge. Peak flows ranged from 0.17 to $22.7 \mathrm{~m}^{3} / \mathrm{s}$ (cubic meters per second), and $\mathrm{pH}$ reached a minimum of 4.9 during 4 of the 14 observed high flows. Nitrate concentrations increased with flow during all but one high flow. An increase in nitrate concentration and an increase in the ratio of sulfate to the sum of base cations was associated with increased acidity of the stream.

When flows exceeded $1.8 \mathrm{~m}^{3} / \mathrm{s}$, values of $\mathrm{pH}$ were less than 5.5 , and aluminum concentrations exceeded $200 \mu \mathrm{g} / \mathrm{L}$ (micrograms per liter). Aluminum concentrations above $200 \mu \mathrm{g} / \mathrm{L}$ occurred during 6 of the 14 observed stormflows. Alkalinity approached zero at flows as low as 2.3 $\mathrm{m}^{3} / \mathrm{s}$. Flows greater than $7.1 \mathrm{~m}^{3} / \mathrm{s}$ had $\mathrm{pH}$ values below 5.0 .

Flow-duration analyses suggested that daily average flows of at least $7.1 \mathrm{~m}^{3} / \mathrm{s}$ are likely to occur once per year on the average. Because low stream $\mathrm{pH}$ is related to high flows, analysis of long-term flow records may enable prediction of the annual frequency of episodic acidification.

\section{INTRODUCTION}

As part of the Acid Precipitation Act of 1980, the U.S. Geological Survey in 1983 began a program of long-term monitoring of surface-water and precipitation chemistry to document trends in surface-water acidification by atmospheric deposition. This program includes 19 watersheds throughout the nation that represent a variety of geographic locations, hydrologic conditions, acidity of deposition, and sensitivity to acidic deposition. Biscuit Brook, a stream with low alkalinity in the Catskill Mountains of southeastern New York (fig. 1), has been monitored since June 1983 for stream discharge, water quality, and precipitation quantity and quality as part of 


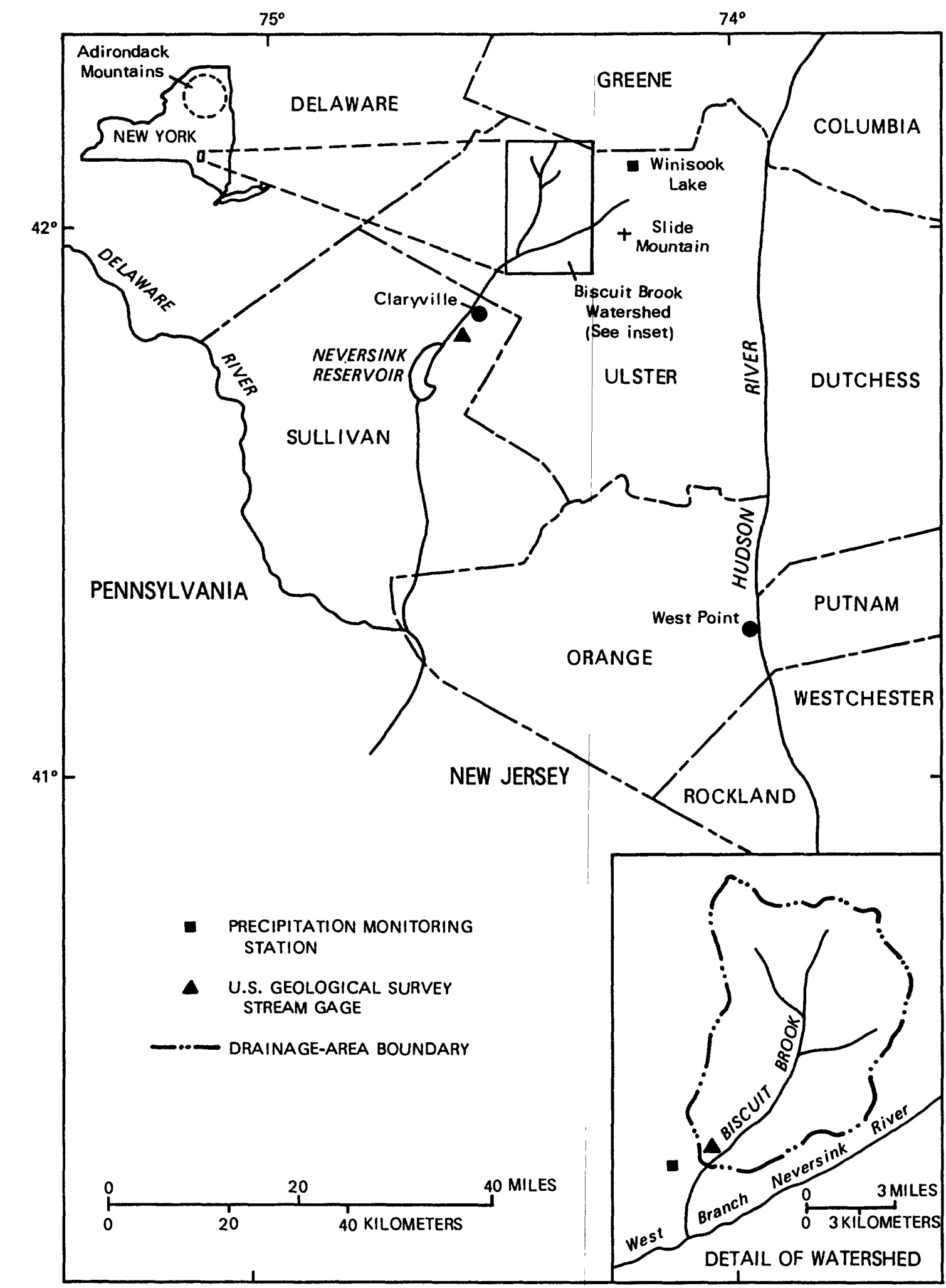

Base from U.S. Geological Survey

State base map, 1:500,000, 1974

Figure 1.--Location of Catskill Mountain region and of Biscuit Brook watershed and watershed-monitoring stations, Ulster County, N.Y. 
this program. Results of seasonal sampling of several streams throughout the Catskills and monthly sampling of six streams near Biscuit Brook, sponsored by the U.S. Geological Survey, the City of New York Department of Environmental Protection, and the U.S. Environmental Protection Agency, indicate that several streams in the region are sensitive to acidic deposition (Murdoch and Barnes, U.S. Geological Survey, written commun., 1983). The first 2 years of data from Biscuit Brook and the six adjacent streams (1984-85) also indicate that the relations between stream discharge and chemical concentrations in Biscuit Brook are representative of those at neighboring streams.

The U.S. Geological Survey monitored stream chemistry and discharge at least biweekly and also during six large storms at Biscuit Brook from October 1984 through September 1985 as part of a national study directed by the Aquatic Effects Group of the U.S. Environmental Protection Agency. (Other streams monitored during the national study are in the Oachita Mountains in Arkansas, the southern Appalachians in Tennessee, and at Laurel Ridge in Pennsylvania.) Biscuit Brook was monitored less frequently during water years 1984 and 1986; results from four storms during water year 1984 and four storms during water year 1986 were available, however, and therefore were included in this analysis. Concentrations of major and minor constituents detected in Biscuit Brook samples during the 3-year period are presented in appendixes $A$ and $B$, respectively; chemical data on precipitation during that period are given in appendix C. Data on Biscuit Brook discharges during the study are given in Firda and others (1984, 1985).

A drought began in the Catskill region in August 1984 and continued through April 1985. Cumulative precipitation during the first 7 months of the study (October 1984 through April 1985) was less than 50 percent of normal at the Slide Mountain National Weather Service station at Winisook Lake, $4.0 \mathrm{~km}$ (kilometers) east of the Biscuit Brook watershed (fig. 1). Rainfall returned to normal during the summer of 1985 but was taken up for soil-moisture replenishment and by evapotranspiration; thus the streams and reservoirs remained at record low levels until Hurricane Gloria deposited $16.9 \mathrm{~cm}$ (centimeters) of rain on september 27, 1985, in the final days of the study (National Oceanic and Atmospheric Administration, 1985). The original study period (October 1984 through September 1985) therefore represented unusual hydrologic conditions for the Catskills and, as such, is not representative of average conditions. Data collected during the previous year, in which rainfall had been normal, were sufficient to compute chemical budgets for Biscuit Brook for water year 1984 .

The purpose of this study was to evaluate the chemical effects of atmospherically derived acidity on stream water in Biscuit Brook and to compare the effects of stormflows on the annual chemical budgets with the effects of base flow. To this end, annual chemical and water-volume budgets were calculated for the 1984 and 1985 water years (October 1, 1983 through September 30,1985$)$, relations between concentration and discharge were defined, and changes in stream chemistry during individual high flows were analyzed for trends. Because no long-term water-quality data base has been established for the Catskill mountain region, results from this 2-year study at Biscuit Brook were compared with stream data from the Adirondack Mountains of New York and Hubbard Brook in New Hampshire, where the effects of acidic deposition have been well documented. 


\section{Purpose and Scope}

This report summarizes the results of water-quality analyses and chemical budgets on Biscuit Brook during water years 1984 and 1985, and assesses the relation between discharge and stream chemistry during 14 storms observed from April 1983 through May 1986 at Biscuit Brook. All chemical data collected are presented in appendixes A through $C_{\text {, }}$ and an analysis of data quality is presented in appendix $D$.

\section{Acknowledgments}

Monitoring of the chemical quality of streams in the Catskill Mountain region is being funded as part of the National Acid Precipitation Assessment Program (NAPAP) by the U.S. Environmental Protection Agency and the U.S. Geological Survey. Special thanks are extended to Frost Valley YMCA, on whose property the Biscuit Brook monitoring station is located, and to James Marion and Claudia Swain of the Frost Valley staff for their observer services.

\section{SITE DESCRIPTION}

The Biscuit Brook watershed lies 600 to $1,100 \mathrm{~m}$ (meters) above sea level, approximately $47 \mathrm{~km}$ west of the Hudson River and $150 \mathrm{~km}$ northwest of New York City (fig. 1). The basin area at the sampling station (U.S. Geological Survey identification no. 01434025 ) is $9.84 \mathrm{~km}^{2}$ (square kilometers) and contains three subcatchment areas surrounded by steep hillsides. The stream drains south into the West Branch Neversink River and subsequently southwest into the Neversink Reservoir and the Delaware River (fig. 1). The Neversink River is well known for its sport fishing, and the Neversink Reservoir is part of the New York City Reservoir system. Hydrologic characteristics of the Biscuit Brook watershed are summarized in table 1 .

Table 1.--Hydrologic characteristics of the Biscuit Brook watershed, Ulster County, N.Y.

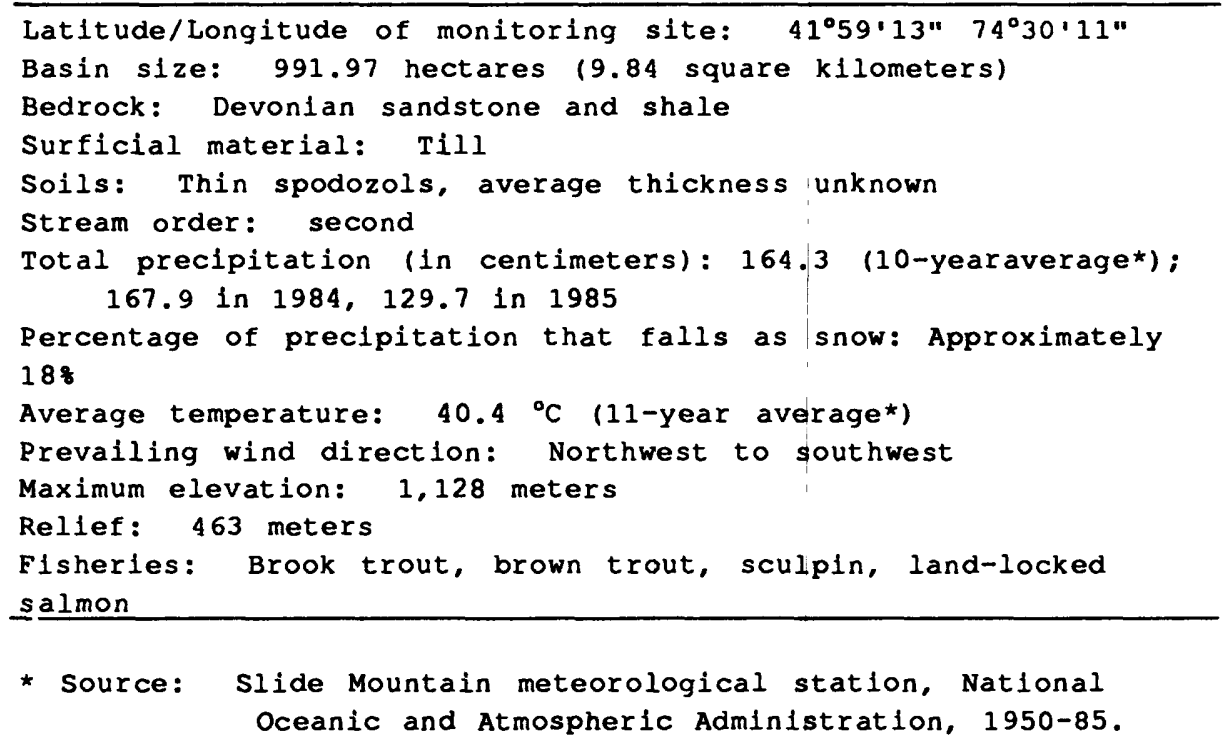


Vegetation in the Biscuit Brook watershed is primarily hardwood forest, including beech, maple, and birch, with scattered hemlock. The watershed above the 730-m elevation contains first-growth forest (Kudish, 1985). Before settlement of the area during 1840-90, the Catskill forests were primarily hemlock. No forest fires were reported after the 1840's (Kudish, 1985). The primary industry was bark peeling of hemlock for tanneries; the trunks were generally left to rot. The upper watershed became a State preserve in 1870; the lower watershed is privately owned by the Frost Valley YMCA and contains a hiking trail and a public lean-to. The watershed is 100 percent forested and is considered pristine.

Bedrock throughout the Catskill region is uniform and generally consists of 60 percent sandstone and conglomerate, and 40 percent mudstone or siltstone (Ethridge, 1977). The rock is part of a Devonian deltaic sequence that forms the northeastern end of the Appalachian plateau. The bedrock is nearly flat lying, with an overall $3^{\circ}$ dip to the southwest (Rich, 1934). It is fractured by three perpendicular joint sets, one of which is parallel to the bedding plane. The bedrock is water bearing but is a fair to poor aquifer. Water from wells in the bedrock is low in dissolved solids, and the specific conductance of stream water is low, which suggests that the bedrock is relatively nonreactive or that water passes through it quickly.

Petrographic analyses conducted by Ethridge (1977) showed that quartz forms approximately 39 percent of the bedrock material, and rock fragments from metamorphic terrain to the east constitute 5 to 48 percent of the detrital fraction. The mineral composition is fairly uniform in the Catskill region. Muscovite is a common accessory mineral, and amphibole is present in small quantities. Calcite and hematite are the primary cement materials, but the amount of interstitial cement is small (Way, 1972). Way (1972) reported pyrite and calcite in the shales along Route 17, more than $25 \mathrm{~km}$ south of the study area, and along route $28,20 \mathrm{~km}$ to the northeast. Thus, both minerals may be present in the watershed.

Surficial materials in the Biscuit Brook watershed have not been mapped since 1934, when the New York State Geological Survey (Rich, 1934) mapped the central Catskill region. That map shows morainic loops, considered to be remnants of small alpine glaciers, lying perpendicular to the stream in at least two places above the sampling station. Most of the remaining watershed is covered by a mantle of till, but the stream channel is predominantly bedrock. Compositionally the till is 97 percent of local origin and may contain some exotics from the Helderberg Limestone, $65 \mathrm{~km}$ to the north (Rich, 1934). The Biscuit Brook watershed therefore contains both thick and thin surficial deposits.

Soils that developed on the till are acidic to highly acidic, thin, and well drained. They are part of the Arnot-Oquaga-Lackawanna Association, which generally form on steep slopes. The subsoil is a bouldery silt loam (till) just below the forest litter (Tornes, 1979).

The climate in the central Catskill Mountains around Biscuit Brook has cold winters and moderately cool summers. Average annual precipitation calculated from 32 years of data from the National weather Service station at winisook Lake (fig. 1) is $157 \mathrm{~cm}$ (National Oceanic and Atmospheric Administration, 1950-82); this site is $4.2 \mathrm{~km}$ east of the Biscuit Brook 
monitoring station at an elevation equivalent to a point on Biscuit Brook approximately $1 / 3$ the total relief above the gage station $(800 \mathrm{~m})$. Average annual air temperature was $15^{\circ} \mathrm{C}$ (degrees Celsius) for the same period. The number of freeze-free days each year averages 127, and snowfall averages 173 $\mathrm{cm} / \mathrm{yr}$ (centimeters per year). Heavy dew is common throughout the central Catskills during the morning hours of the freeze-free period.

\section{METHODS}

All methods of sample handling and preservation were in accordance with the National Trends Network (NTN) protocol for precipitation (National Acid Deposition Program, 1982) and special quidelines developed by the U.S. Environmental Protection Agency and the U.S. Geological Survey for low-ionicstrength waters.

\section{Water Budget}

Precipitation volume was measured continuously at the NTN station in the lower Biscuit Brook watershed (elevation $634 \mathrm{~m}$ ) with a weighing-bucket recording rain gage. Daily precipitation volume was also measured with a standard wedge-type gage in the lower watershed and at the National Weather Service Slide Mountain station at Winnisook Lake (elevation $808 \mathrm{~m}$ ).

Evapotranspiration (ET) was estimated by the method of Hamon (1961) from daily maximum and minimum temperature readings taken at winisook lake. A comparison of several estimation methods used in a study of lake acidification in the Adirondack Mountains showed this method to yield the best estimate of ET in mountainous terrain (Murdoch and others, 1987).

Water levels in Biscuit Brook were recorded by a gas-purge servomanometer assembly attached to an analog-digital recorder at the site where water samples were taken for chemical analysis. Stage-versus-discharge relations were developed through standard U.S. Geological Survey methods (Rantz, 1982).

Calculated monthly values for precipitation, discharge, and evapotranspiration were used to estimate a water balance for Biscuit Brook from the standard water-budget equation:

$$
P=R+E T+\Delta S T
$$

where: $P=$ precipitation,

$R=$ runoff,

$E T=$ evapotranspiration, and

$\Delta S T=$ change in storage.

Monthly changes in storage were assumed to represent the residual of the water-budget equation and included ground water, soil water, and water temporarily stored on the surface of the watershed as snow or ice. 


\section{Chemical Budget}

Wet-precipitation samples were collected weekly at the NTN station in an Aerochem ${ }^{1}$ wetfall-dryfall collector. Rain samples from individual storms were collected at the NTN and Slide Mountain stations when stream-water quality was monitored. The storm collector was a polyethylene funnel and bottle system with a plastic cover screen. Wet-precipitation samples from the wetfalldryfall collector were sent to the Illinois State water Survey laboratory for analysis for major anions and cations. Quality-assurance procedures for these analyses were as described in the NADP (National Acid Deposition Program) Quality Assurance Plan (NADP Quality Assurance Steering Committee, 1984). Precipitation samples from individual storms were sent to the U.S. Geological Survey Central Laboratory in Denver, Colo.

Stream water was sampled weekly during base flow and at intervals as short as $1 / 2$ hour during flow peaks. Sampling intervals during flow peaks were determined by field observations of $\mathrm{pH}$, specific conductance, alkalinity, and rates of change in flow. Stream samples were collected either by hand in 2liter Teflon bottles for immediate processing (within 2 hours) or by an automatic sampler activated by observers in anticipation of high flows. The latter samples were retrieved within 24 hours of sampler activation and chilled until processing. Samples from the automatic sampler were filtered within 48 hours.

Stream samples were passed through $0.1-\mu$ (micrometer) polycarbonate filters to minimize particulate contamination in dissolved-constituent analyses and were stored at $4^{\circ} \mathrm{C}$ until analysis. Samples for cation analyses were acidified with 1-Normal ultrapure nitric acid. Samples for dissolved organic carbon were filtered through $0.4-\mu$ silver filters and chilled. Field $\mathrm{pH}$ was measured with a low-ionic-strength electrode calibrated with standard buffers and checked with a low-ionic-strength sulfuric acid standard. Specific-conductance meters were calibrated regularly with low-conductance standards. Alkalinity measurements were hand titrated and calculated by the Gran's plot technique. Air and water temperature were measured during each visit. Filtered samples were packed in ice and shipped immediately to the U.S. Geological Survey Central Laboratory in Arvada, Colo., where they were analyzed for major anions $\left(\mathrm{Cl}, \mathrm{F}, \mathrm{NO}_{3}, \mathrm{PO}_{4}, \mathrm{SO}_{4}\right)$ by ion chromatography, for major cations and metals ( $\mathrm{Ca}, \mathrm{K}, \mathrm{Na}, \mathrm{Mg}, \mathrm{Si}, \mathrm{Fe}, \mathrm{Mn}$ ) by indirect coupled plasma, for aluminum by direct coupled plasma, and for dissolved organic carbon by persulfate oxidation and infrared spectrometry (Fishman and Friedman, 1985; Wershaw and others, 1983). Quality-control procedures included (1) duplicate sampling on 10 percent of the samples collected, (2) analysis of the deionized water used in sample preparations, (3) comparison of total anion concentration with total cation concentrations, (4) comparison of calculated specific conductance values with measured values, and (5) reanalysis of samples when data appeared in error. Results of the qualitycontrol analyses are given in appendix $D$.

Average daily concentrations of chemical constituents of stream water were estimated by two methods--a concentration-versus-discharge regression analysis

1 Use of trade names in this report is for identification purposes only and does not constitute endorsement by the U.S. Geological Survey. 
and, if a poor relation was observed, by a graphic interpolation method. The concentration-versus-discharge method, which was developed for Hubbard Brook, N.H. (Johnson and others, 1969), generates equations for estimating daily concentrations from the flow hydrograph. The regression analysis considers linear, logarithmic, inverse, and eight hyperbolic mathematical relations between constituent concentration and discharge and selects the best-fit relation by computing a t-test statistic for the correlation coefficient ( $r$ ) and selecting the maximum square of the correlation coefficient $\left(r^{2}\right)$ (Peters and others, 1982). The equation used for the eight hyperbolic relations in the analysis is:

$$
C=\frac{1}{1+\beta D} S+I
$$

where: $\quad C=$ observed solute concentration after mixing (in microequivalents per liter),

$D=$ daily stream discharge (in cubic feet per second),

$S=$ resultant slope value (change in concentration after mixing),

$I=$ resultant intercept value (concentration of solute added to the stream),

$\beta=$ bet $a, a$ constant.

The eight hyperbolic relations differ by the beta value used in each of the regression runs.

The method has been successfully applied to Hubbard Brook, N.H. by Johnson and others (1969) and to streams in the Adirondack Mountains of New York by Peters and others (1982) and is considered more accurate than the graphic interpolation method of calculating daily loads as long as the regression $r^{2}$ values for the concentration-verses-discharge relation are significant. The graphic interpolation method is similar to that used by the U.S. Geological Survey in determining daily stream-sediment loads (Porterfield, 1972) and involves interpolating between data points along a temporal graph. Interpolation between dates with concentration data was done in accordance with the hydrograph characteristics and the concentration values of the samples taken before and after the period of missing data.

Chemical budgets were calculated as a running sum of the weekly net difference between input (wet precipitation load) and output (stream yield), which allows observation of weekly changes in the balance during the study. Chemical contributions from wet precipitation were calculated from weekly chemical data taken at the NTN station in the lower Biscuit Brook watershed and from daily volume data collected at the National Weather Service Slide Mountain station at Winisook Lake. Chemical yields in stream water were calculated from daily stream concentration and discharge values and were summed for weekly intervals corresponding to the period of rain-sample collection. (Rain samples were collected each Tuesday at the NTN station; thus, weekly flux tabulations begin on Tuesday, and the annual chemical budgets begin on the first Tuesday of October for each year studied.)

Chemical budgets were calculated for the major anions $\left(\mathrm{SO}_{4}, \mathrm{NO}_{3}, \mathrm{Cl}\right.$, and alkalinity) and the major cations ( $\mathrm{Ca}, \mathrm{Mg}, \mathrm{Na}, \mathrm{K}, \mathrm{H}$, and $\left.\mathrm{NH}_{4}\right)$ and are reported in equivalents per hectare $(\mathrm{eq} / \mathrm{ha})$. Weekly differences between precipitation load and stream yield were summed to create the cumulative annual chemical budget. 


\section{Stormflow Chemistry}

Data from intensive sampling of nine separate storm-related flow peaks and five snowmelt-related flow peaks were plotted against time to determine the relative timing of discharge and concentration peaks and depressions, rates of change in stream chemistry in relation to discharge, and indications of separation between shallow- and deep-flow pathways in the watershed. Chemical concentrations were plotted against discharge to identify threshold flow values above which alkalinity is zero and hydrogen and aluminum concentrations reach levels known to be toxic to fish. Flow-duration curves, which illustrate the percentage of time a certain flow is equaled or exceeded, were then plotted to predict the number of days per year on which toxic conditions may be expected.

\section{WATER BUDGET}

Results of the water-budget calculations are presented in table 2. As explained in later sections, the annual chemical budgets for Biscuit Brook were strongly dependent upon the hydrology of each period studied; therefore, calculation of accurate water budgets was critical to the investigation of stream-chemistry changes. Results of the water-budget calculations are presented in table 2, and the analysis of each component in the water budget is discussed in the following sections.

\section{Components of the Water Budget}

\section{Precipitation}

Annual precipitation was $168 \mathrm{~cm}$ during water year 1984 and $129.7 \mathrm{~cm}$ in water year 1985 (referred to as WY84 and WY85 hereafter). The 10-year annual average for the central Catskill region was $164.3 \mathrm{~cm}$ (National Oceanic and Atmospheric Administration, 1975-84). Heavy rain during April and May 1984 (fig. 2) caused flooding in parts of the Catskill area. Precipitation was low from June 1984 until June 1985, and streamflows were low through late

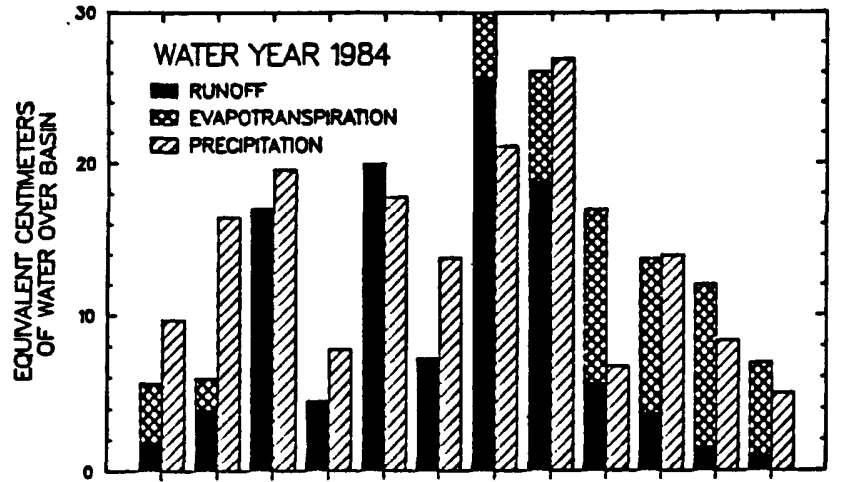

Oet Nov Dec Jon Feb Mor Apr Moy June July Aug Sept

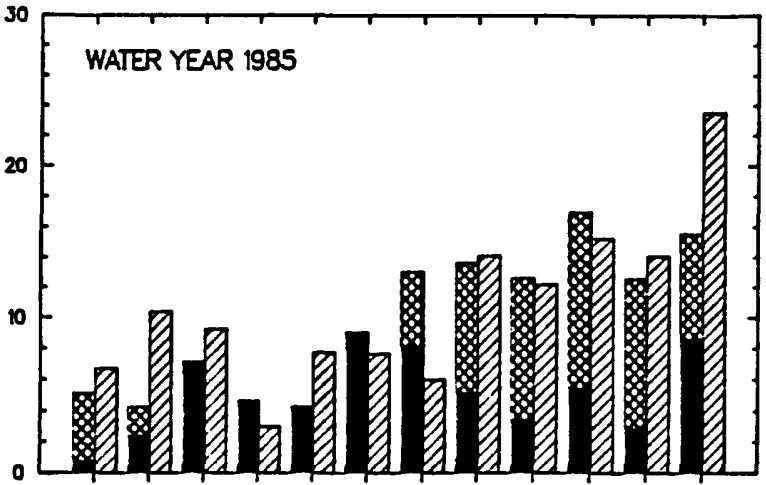

Oct Nov Dec Jan Feb Mar Apr May June July Aug Sept

Figure 2.--Monthly discharges, evapotranspiration, and precipitation at Biscuit Brook watershed, October 1983 through September 1985. 
September 1985 because high evapotranspiration offset the renewed normal rainfall. On September 26 and 27 of WY85, Hurricane Gloria and the preceding frontal storm deposited 13 percent of the year's rainfall, which brought poststorm streamflow back to near-normal conditions. The study period loctober 1983 through September 1985) can therefore be summarized as having heavierthan-normal precipitation and runoff during most of the first year, followed by 13 months of below-normal precipitation and fewer discharge peaks than usual, and culminating with 3 days of high stream discharge from Hurricane Gloria.

Table 2.-Monthly water-balance estimates for water years 1984 and 1985 at Biscuit Brook.

[All values in equivalent centimeters of water. Numbers in parentheses indicate percentage of year's total precipitation.]

\begin{tabular}{|c|c|c|c|c|c|c|c|}
\hline \multirow{2}{*}{$\frac{\text { Year }}{1983}$} & \multirow{2}{*}{$\frac{\text { Month }}{\text { October }}$} & \multirow{2}{*}{$\begin{array}{l}\begin{array}{l}\text { Precipi- } \\
\text { tation }\end{array} \\
9.88\end{array}$} & \multicolumn{2}{|l|}{ Runoff } & \multicolumn{2}{|c|}{$\begin{array}{l}\text { Evapotrans- } \\
\text { piration }\end{array}$} & \multirow{2}{*}{$\begin{array}{c}\begin{array}{c}\text { Change in } \\
\text { Storage }\end{array} \\
+4.16\end{array}$} \\
\hline & & & 1.83 & & 3.89 & & \\
\hline & November & 16.46 & 3.96 & & 2.01 & & +10.49 \\
\hline & December & 19.58 & 17.20 & & 0 & & +2.38 \\
\hline \multirow[t]{9}{*}{1984} & January & 7.80 & 4.52 & & 0 & & +3.28 \\
\hline & February & 17.78 & 20.40 & & 0 & & -2.62 \\
\hline & March & 13.79 & 7.32 & & 0 & & +6.47 \\
\hline & April & 21.13 & 25.96 & & 4.29 & & -9.12 \\
\hline & May & 26.92 & 18.95 & & 7.34 & & +.63 \\
\hline & June & 6.71 & 5.64 & & 11.38 & & -10.31 \\
\hline & July & 13.97 & 3.71 & & 11.53 & & -1.27 \\
\hline & August & 8.38 & 1.52 & & 10.54 & & -3.68 \\
\hline & September & 5.64 & .89 & & 6.07 & & -1.32 \\
\hline WY84 & Total & 168.0 & 111.9 & $(67)$ & 57.0 & (34) & -0.91 \\
\hline \multirow[t]{3}{*}{1984} & October & 6.70 & 0.76 & & 4.36 & & +1.57 \\
\hline & November & 10.39 & 2.41 & & 1.85 & & +6.13 \\
\hline & December & 9.24 & 7.11 & & 0 & & +2.13 \\
\hline \multirow[t]{9}{*}{1985} & January & 2.97 & 4.04 & & 0 & & -1.07 \\
\hline & February & 7.72 & 4.01 & & 0 & & +3.71 \\
\hline & March & 7.64 & 8.97 & & 0 & & -1.33 \\
\hline & April & 5.97 & 8.15 & & 4.92 & & -7.00 \\
\hline & May & 14.10 & 5.13 & & 8.51 & & +.46 \\
\hline & June & 12.17 & 3.38 & & 9.24 & & -.45 \\
\hline & July & 15.24 & 5.49 & & 11.51 & & -1.76 \\
\hline & August & 14.07 & 3.15 & & 9.71 & & +1.21 \\
\hline & September & 23.49 & 8.74 & & 6.96 & & +7.79 \\
\hline WY 85 & Total & 129.7 & 61.3 & $(47)$ & 57.1 & $(44)$ & +11.29 \\
\hline \multicolumn{8}{|c|}{ TOTAL FOR BOTH } \\
\hline YEARS & & 297.7 & 173.2 & $(58)$ & 114.0 & $(38)$ & +10.38 \\
\hline
\end{tabular}


Seasonal distribution of precipitation and runoff at Biscuit Brook in wY 84 differed greatly from that in WY85. Nearly 80 percent of the precipitation in WY84 fell before June, whereas more than 50 percent of the precipitation in WY85 fell from June through september. Consistent with this pattern, runoff from June through September formed only 10.5 percent of the annual runoff in WY 84 but formed 33 percent of the annual runoff in WY85. About 65 percent of the annual runoff occurred during the spring snowmelt in WY84, compared to only 43 percent in WY85.

\section{Streamflow}

Plots of daily stream discharge (fig. 3) show that peak flows in WY85 were substantially smaller than in WY84. Daily mean discharge in WY85 ranged from 0.015 to $5.32 \mathrm{~m}^{3} / \mathrm{s}$, but the maximum daily discharge was only $1.25 \mathrm{~m}^{3} / \mathrm{s}$ if Hurricane Gloria is omitted. Daily mean discharge during WY 84 ranged from 0.019 to $8.41 \mathrm{~m}^{3} / \mathrm{s}$, with five peaks greater than $2.83 \mathrm{~m}^{3} / \mathrm{s}$. Daily base flows of WY84 were similar to those of WY85, although spring base flow was slightly greater in WY84, and fall base flow was slightly greater in WY85 (fig. 3). The primary hydrologic difference between WY 84 and WY 85 therefore is the magnitude and frequency of discharges that exceeded the seasonal base flow.

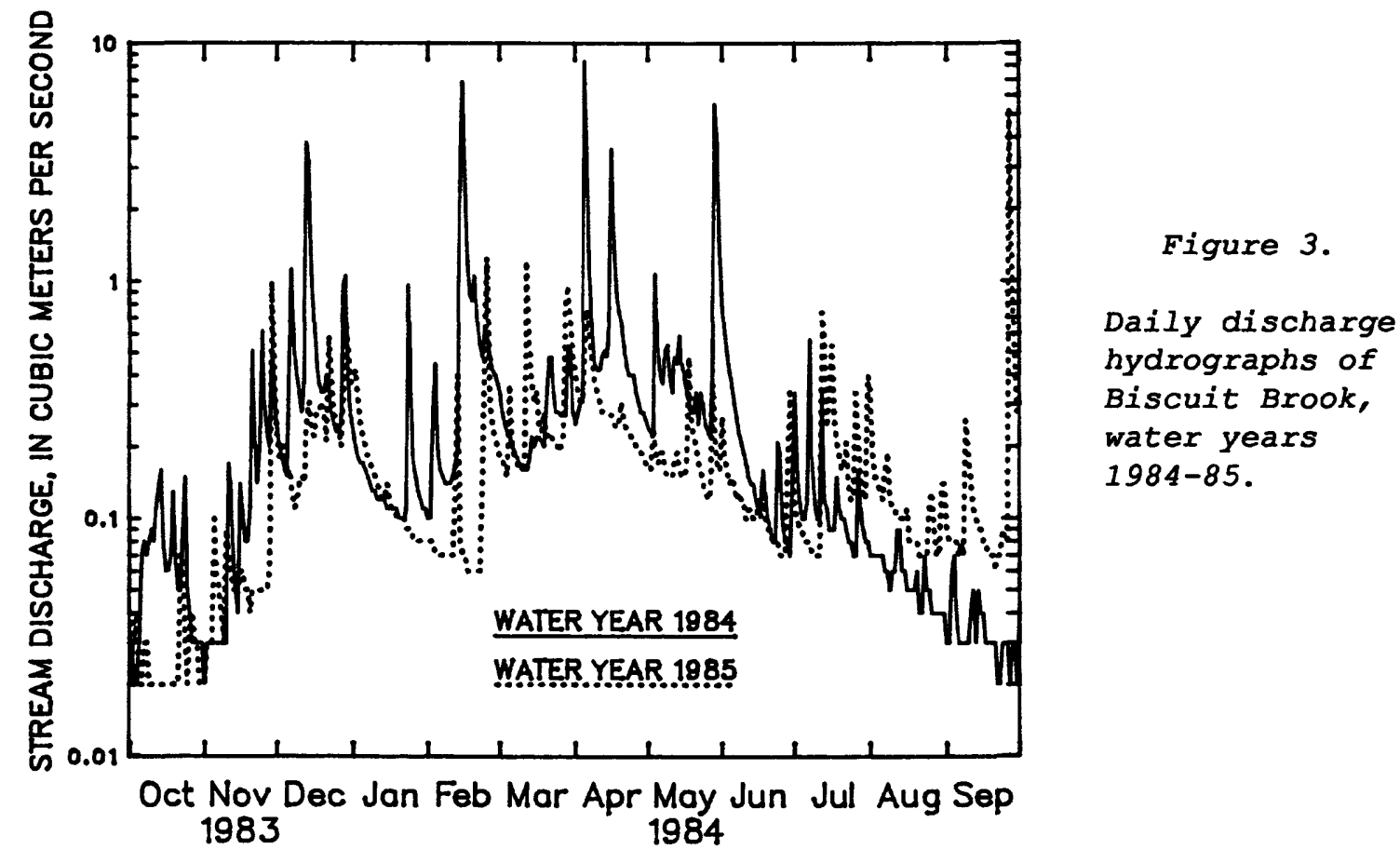

\section{Evapotranspiration}

Evapotranspiration (ET) was similar in magnitude in both years but amounted to 34 percent of the annual precipitation in WY 84 and 44 percent of that in WY85 (table 2). Before Hurricane Gloria, ET plus changes in storage accounted for 51 percent of the precipitation for WY85. Thus, the decreased precipitation in WY85 appears to have been reflected primarily as decreased runoff, and evapotranspiration remained relatively constant from year to year. 
The storage term in the water budget could represent actual water storage in the basin but also could include ground-water discharge from the basin and may reflect errors in the other three components of the water-budget equation. Net change in storage can be assumed negligible on an annual basis if stream base-flow values at the beginning and end of the period are similar and if no ground-water discharge occurs (Murdoch and others, 1987). Base-flow values at the beginning and end of WY84 were similar to those just before Hurricane Gloria near the end of WY85 (fig. 3). If any net change in storage occurred, it would have been a net deficit due to the drought at the end of WY 84 . The stream channel at the gage and nearthe drainage divide are both bedrock, which is considered a poor aquifer and thus allows little or no ground-water seepage (Parker and others, 1964); therefore, net annual storage was considered negligible, and monthly storage values were assumed to represent actual watershed storage (as well as errors in the precipitation, runoff, and evapotranspiration values).

Monthly watershed storage increased during the winter of both years and decreased during the spring and summer of both years (table 2). Both years had two periods of snowmelt during the spring, separated by a month of net reaccumulation of the snowpack. Unusually heavy rains in May 1984 caused a slight increase in storage that month, followed by a large net loss of storage during June as the drought period began. Net storage increased at the end of WY85 as the year-long drought subsided, and most of the September recharge resulted from Hurricane Gloria.

\section{Error in the Water Balance}

The combined error in precipitation and discharge measurements, by analogy with investigations of error in previous studies that used similar equipment and techniques, ranges from 10 to 15 percent each (Winter, 1981; Murdoch and others, 1987). Estimates of annual evapotranspiration plus changes in storage, made by subtracting runoff from precipitation, could therefore be in error by 20 to 30 percent. Estimates of monthly evapotranspiration calculated from maximum and minimum daily temperature data from the NWS Slide Mountain station at Winisook Lake probably were more representative of the Biscuit Brook watershed than estimates calculated from temperature data from the station at the lower end of the watershed because air temperature is affected by elevation. (Some error is possible in the temperature readings because the ET equation does not account for cloud cover or rain.) Large error is therefore possible in the monthly ET and storage values, but the probable percent error could not be determined.

\section{Comparison with Water Budgets for Other Parts of the Northeast}

Comparison of rainfall at Biscuit Brook with rainfall at other precipitation stations in New York shows that the central Catskill Mountains receive substantially greater precipitation than other upland areas (table 3 ). This is partly explained by the Catskills' location in an area that received storms from the south along the Atlantic coast as well as from the west. Precipitation data also show that all of New York during 1984-85 received 
rainfall below the 10-year average (National Oceanic and Atmospheric Administration, 1974-1985).

The evapotranspiration value used in the annual water budget is comparable to other estimates for the Catskills and nearby regions that are based on long-term precipitation and streamflow data (Knox and Nordenson, 1955) and adjusted pan-evapotranspiration data (U.S. Department of Commerce, 1968); it also is similar to estimates for the Adirondack Mountains that are based on three empirical equations, including the Hamon equation (Murdoch and others, 1987). The percentage of precipitation that becomes surface runoff is therefore slightly greater in the Catskills than in the other regions, which receive less rain.

Table 3.--Annual precipitation at Biscuit Brook and other measurement stations in New York.

All values in centimeters; a dash indicates data were unavailable; data from National Oceanic and Atmospheric Administration, 1975-84, locations are shown on map.]

\begin{tabular}{|c|c|c|c|c|c|c|c|c|c|c|c|}
\hline Location & 1975 & 1976 & 1977 & 1978 & 1979 & 1980 & 1981 & 1982 & 1983 & 1984 & Avg \\
\hline Upper Biscuit Brook* & 175 & 172 & 183 & 159 & 202 & 131 & 168 & 134 & 180 & 149 & 165 \\
\hline 2. Lower Biscuit Brook & 167 & 156 & 165 & 126 & 173 & 111 & -- & -- & -- & 135 & 148 \\
\hline 3. Finger Lakes & 104 & 113 & 118 & 81 & 92 & 80 & 99 & 80 & 90 & 105 & 96 \\
\hline 4. Taconic Plateau & 151 & 134 & 137 & 88 & 116 & 98 & 126 & 112 & 135 & 130 & 123 \\
\hline 5. Western Catskills & 139 & 131 & 138 & 104 & 125 & 103 & 97 & 96 & 117 & 131 & 118 \\
\hline 6. Southern Catskills & 144 & 1.36 & 139 & 111 & 130 & 88 & 104 & 101 & -- & 116 & 107 \\
\hline 7. Western Adi rondacks & 145 & 173 & 159 & 127 & 118 & 120 & 121 & 116 & 125 & 119 & 132 \\
\hline
\end{tabular}

* Specific monitoring stations are:

1. Slide Mountain Station at Winisook Lake

2. Frost Valley

3. Cornell University at Ithaca

4. Grafton
5. Downsville Dam at Downsville
6. Grahamsville
7. Big Moose

\section{Flow-Duration Analysis}

A flow-duration curve is a cumulative frequency curve that shows the percentage of time that specified discharges were equaled or exceeded during a given period (Searcy, 1963). The shape of the curve is determined by the hydrologic and geologic characteristics of the watershed and by the amount of precipitation during the period represented. Flow-duration curves are generally developed for streams that have long periods of record. Comparisons of the 2-year flow duration at Biscuit Brook with the 32-year record from the Geological Survey's gaging station on the Neversink River near Claryville (fig. 1 and Firda and others, 1984) can be used to estimate longer-term characteristics of Biscuit Brook hydrology than would be possible with the 2year record, however.

Flow-duration curves for Biscuit Brook and the Neversink River at Claryville were plotted as discharge per unit area to facilitate comparison. The WY84 and WY85 curves for Biscuit Brook are similar at low flows (those that are equaled or exceeded more than 70 percent of the time) (fig. 4), but 
the WY84 high-flow values for given frequencies exceed those of WY 85 by as much as 40 percent. The steep, fairly uniform slope of the curves indicates a stream with highly variable flows and little water retention within the basin, and the lack of curve flattening beyond 90-percent duration also suggests negligible storage capacity. The lack of flattening below 10-percent duration indicates that high flows during the study came primarily from rainfall rather than snowmelt, which is consistent with the small snowpack that developed. The flow-duration curve for WY84 (fig. 4) is steepest just below the 10percent-frequency level, which suggests high flows of short duration during that period. The similarity of the WY 84 and WY85 curves above 70-percent duration suggests ground-water storage, however, because the low-flow values were the same despite large differences in peak flows each year.

The WY84 flow-duration curve for the Neversink River roughly matches that for the period of record (1953 to present, fig.4). The WY 85 curve has lower flows than the long-term curve over the entire range of frequencies, however, which indicates that WY85 was a year of lower-than-normal streamflow in the Neversink basin, of which Biscuit Brook is a part. Flows in the 75-percent duration range for WY 85 were closer to the long-term values than flows in other ranges, which further indicates some ground-water storage in the basin. Flow-duration curves for Biscuit Brook are similar to the Neversink curves at high flows (those above 35 percent duration in WY 84 and above 50 percent in WY85). At lower flows, the Neversink has greater flow per unit area for a given flow frequency than Biscuit Brook, which is consistent with greater ground-water storage in the thicker valley deposits of the larger basin. The flow-duration curves therefore indicate that WY84 was hydrologically typical for the Neversink system, whereas WY85 had lower peak flows.
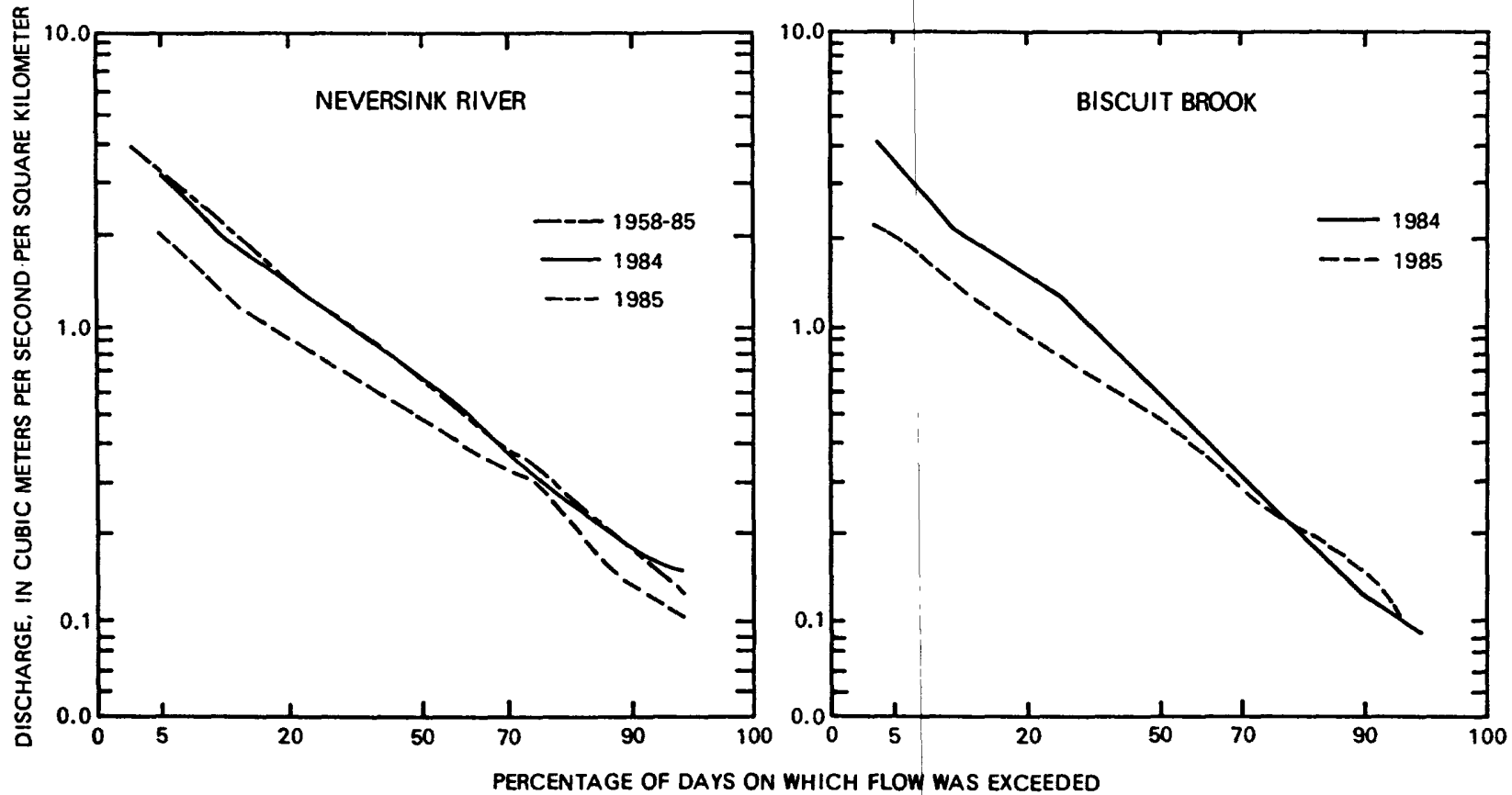

Figure 4,--Flow-duration curves for Neversink River near Claryville, water years 1953-85, and Biscuit Brook, water years 1984-85. 


\section{PRECIPITATION CHEMISTRY}

\section{Ion Concentrations and Deposition Rates}

Hydrogen and sulfate ions were the dominant chemical constituents in precipitation at Biscuit Brook during the study. Hydrogen ion accounted for 62 percent of the total cation concentration, in $\mu \mathrm{eq} / \mathrm{L}$ (microequivalents per liter), during WY84 and 67 percent during wY85 (table 4). The next most abundant cation was ammonium, which made up 16.5 percent of the total cations in both years. Sulfate ion constituted 57 and 59 percent of total anion concentration during $W Y 84$ and wY85, respectively, and nitrate ions made up 34 percent of the total anion concentration in both years. The anion-to-cation ratio during WY 85 was 0.97 and during WY 84 was 0.81 . The apparent excess of cations in wY84 may be partly explained by the fact that several of the rain samples collected during wY84 were bulk samples. The average $\mathrm{pH}$ of precipitation during both years was approximately 4.25 , but weekly values ranged from 3.25 to 5.92 . The average sulfate concentration increased from $40.1 \mu \mathrm{eq} / \mathrm{L}$ in WY84 to $47.8 \mu \mathrm{eq} / \mathrm{L}$ in WY85 and showed large variation from week to week. The precipitation entering the Biscuit Brook watershed therefore appears to be a dilute solution of sulfuric and nitric acid in which the percentage of each fluctuates continuously.

Concentrations of total dissolved solids were similar in the spring and summer for both years (fig. 5). Chloride concentrations were greatest in the winter; sulfate and hydrogen both showed increasing concentration from fall to summer; ammonium concentrations were greatest during the spring of both years. Nitrate concentrations were relatively uniform during the winter, spring, and

Table 4.--Average $p H$ and concentrations of dissolved constituents in weekly precipitation samples from Biscuit Brook and other monitoring stations in the northeastern United States.

[Values in microequivalents per liter, a dash indicates data were unavailable. Locations shown on map.]

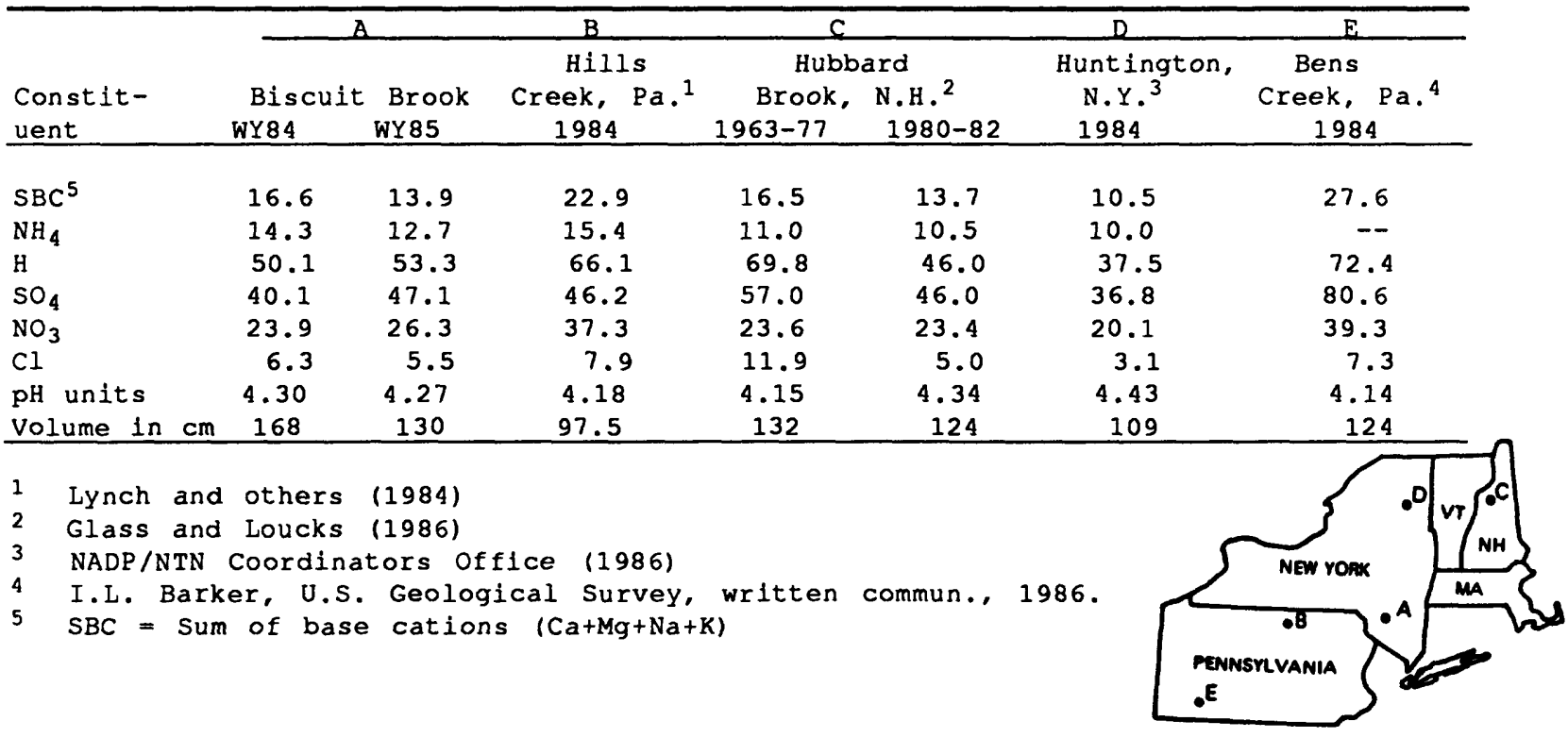


summer, but were $10 \mu \mathrm{eq} / \mathrm{L}$ lower during the fall of both years than during the other seasons. Weekly fluctuations in anion concentrations were far greater than seasonal fluctuations. (See appendix C).

Sulfate and nitrate deposition (concentration times volume) was greatest during the spring and midsummer of WY 84 and the late summer of WY85, which were the periods of greatest precipitation volume (fig. 2). Chloride deposition was greatest in late winter and spring of both years, and hydrogen deposition showed similar trends. The greatest difference in deposition rates between the two years occurred during spring-the wY84 deposition of all major constituents was approximately twice those of WY85.

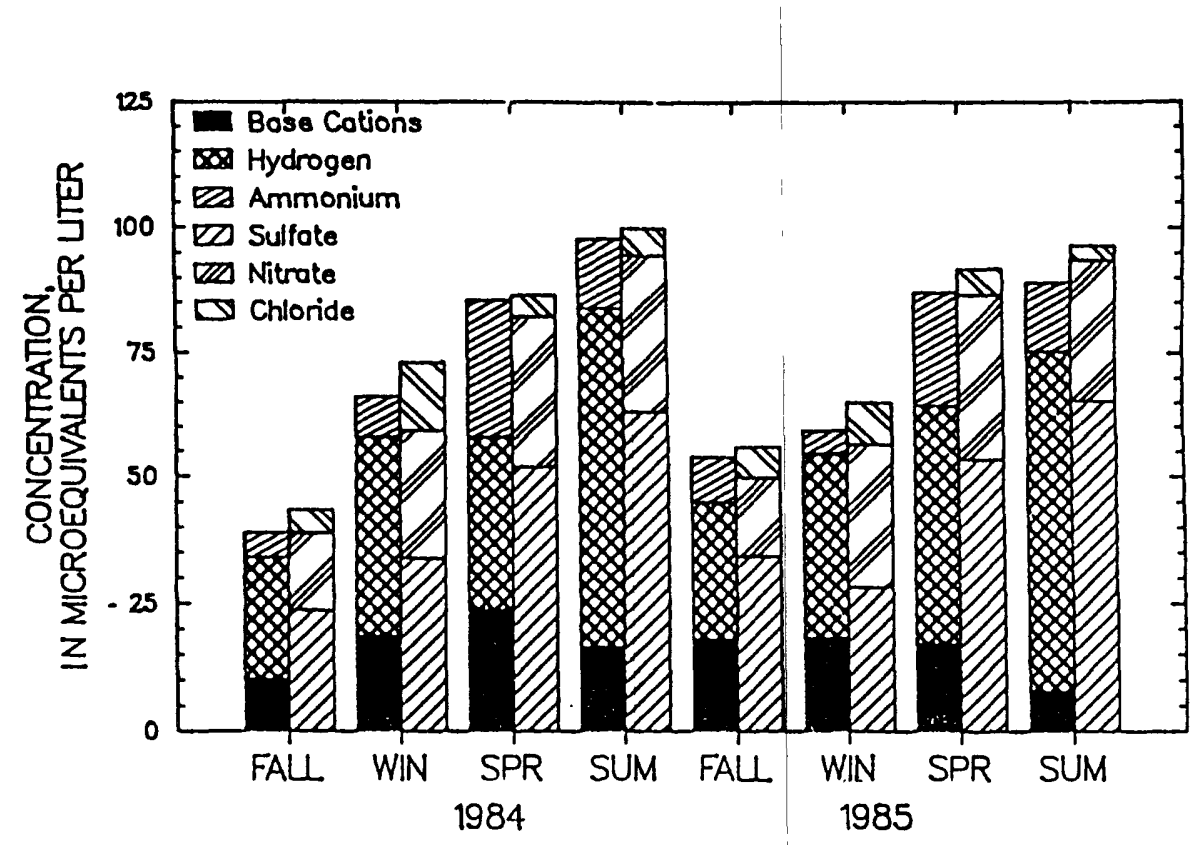

Figure 5.--Seasonal concentrations of chemical constituents in precipitation at Biscuit Brook, water years 1984-85.

\section{Comparison with other Monitoring Stations in the Northeast}

Average concentrations of major dissolved ions in precipitation as Biscuit Brook during the study were similar to concentrations observed at other precipitation-collection stations in the northeast (table 4). Hydrogen-ion concentration in precipitation at Biscuit Brook was lower than the 15-year volume-weighted average (1963-77) at Hubbard Brook Experimental Forest (HBEF), N.H., but was similar to that for a dry period at HBEF during 1980 and 1981 (table 4) (Glass and Loucks, 1986). Similarly, chloride and sulfate concentrations at Biscuit Brook were slightly lower than the HBEF 15-year average but were similar to the 1980-82 data.

Average concentrations of dissolved constituents in precipitation at Huntington, N.Y., were slightly lower in 1984 than those observed at Biscuit 
Brook (NADP/NTN Coordinators Office, 1986). The station at Hills Creek, Pa., approximately $160 \mathrm{~km}$ southwest of the Catskills, reported slightly higher concentrations of all constituents during WY84 than Biscuit Brook (Lynch and others, 1986). The station at Laurel Ridge, in southwestern Pennsylvania, received substantially higher sulfate concentrations than Biscuit Brook during both WY84 and WY85 (table 4) (J. L. Barker, U.S. Geological Survey, written commun., 1986). This pattern of an eastward decrease in sulfate concentrations in precipitation is consistent with a midwestern source of the sulfate.

The chemical deposition rates observed at Biscuit Brook during the study are also within the range of those observed at Hubbard Brook, N.H., and at Woods Lake in the Adirondack Mountains. Annual nitrate deposition during 1963-77 at Hubbard Brook ranged from 108 to 500 eq/ha (equivalents per hectare) (Likens and others, 1977), and those for 1978-81 at Woods Lake ranged from 380 to $460 \mathrm{eq} / \mathrm{ha}$ (Johannes and others, 1985). Nitrate deposition at Biscuit Brook was $447 \mathrm{eq} / \mathrm{ha}$ in WY84 and $341 \mathrm{eq} / \mathrm{ha}$ in WY85. The deposition of acidic anions, ammonia, and hydrogen at Biscuit Brook was slightly greater than at Hubbard Brook during a period when precipitation volume was similar at both sites $(124 \mathrm{~cm} / \mathrm{yr}$ from December 1980 through November 1982 at Hubbard Brook and $130 \mathrm{~cm} / \mathrm{yr}$ from October 1984 through September 1985 at Biscuit Brook), but the base-cation values were similar (Glass and Loucks, 1986). The ranges in chemical concentrations and deposition rates observed at Biscuit Brook are therefore similar to those at other monitoring stations in the Northeast, and the longer-term data at Hubbard Brook suggest a decrease in deposition of sulfate since the 1960 's. However, the long-term average values for annual precipitation indicate that the Catskills receive a greater precipitation volume, and therefore greater annual chemical loads, than the other stations.

\section{STREAM CHEMISTRY}

\section{Average Concentrations}

Average volume-weighted concentrations of major constituents in Biscuit Brook indicate significant chemical interaction between precipitation and watershed materials (tables 4,5 ). The total concentration of dissolved constituents in the stream was 2.3 times that in precipitation, which can be attributed to the concentrating effect of evapotranspiration (44 percent of precipitation in WY 85 ). The proportions of the ions to one another in stream water differed substantially from those in precipitation, however, which indicates that chemical reactions or ion exchange within the watershed affect stream chemistry.

Stream chemistry of Biscuit Brook is dominated by calcium, sulfate, and nitrate (fig. 6). Calcium replaces hydrogen from precipitation as the dominant cation and accounts for 63 percent of the total cations. The average annual hydrogen concentration is insignificant 13 percent of total cation concentration). Distribution of major cations by equivalents was $\mathrm{Ca}>\mathrm{Mg}>\mathrm{Na}$ $>K$, and the relative concentrations of these constituents did not change appreciably with changes in flow. Potassium concentration increased with flow 


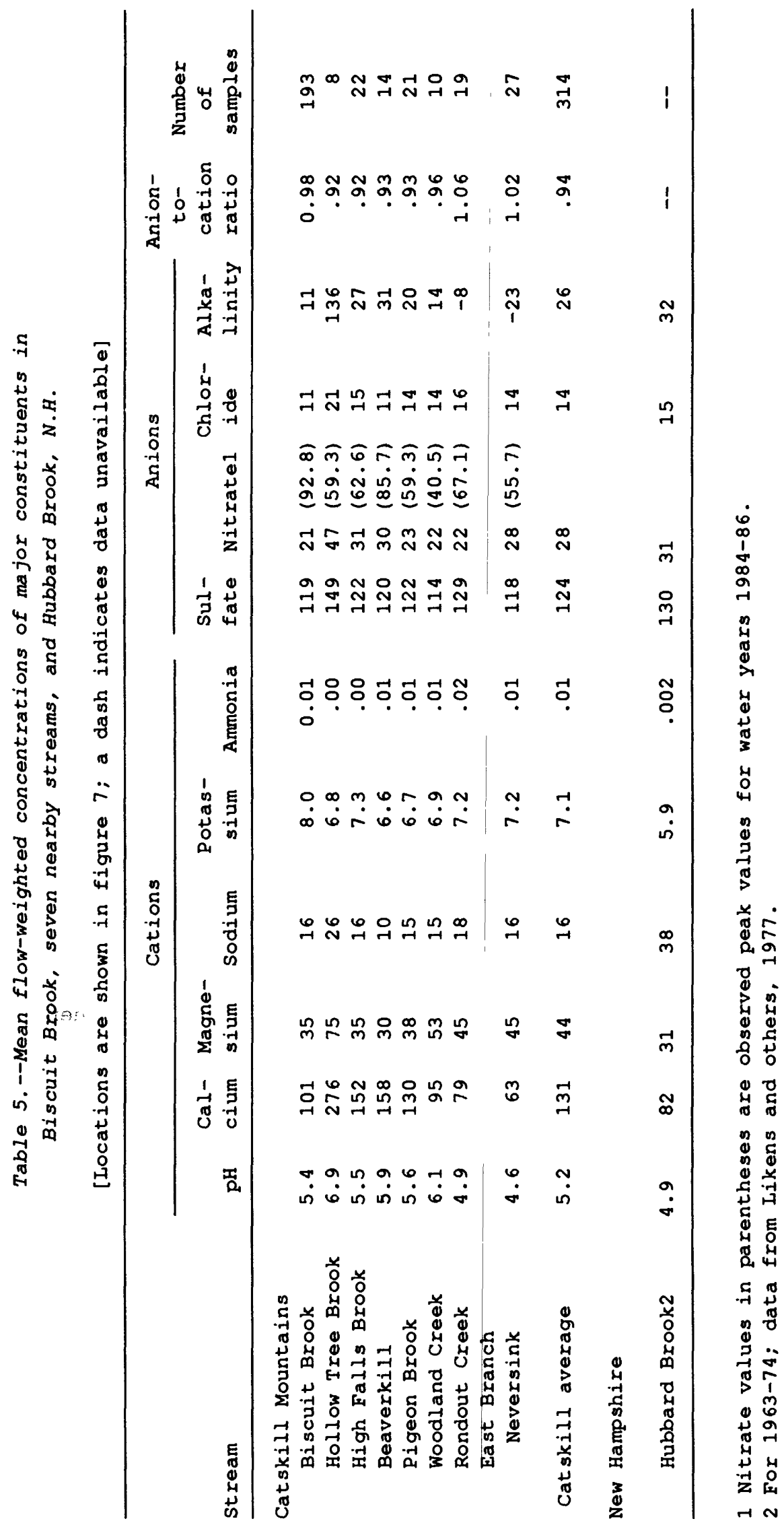


during the observed storms, however. Aluminum and hydrogen accounted for as much as 11 percent and 5 percent, respectively, of the total cations during peak flows. The general absence of ammonium except at high flows suggests nearly complete assimilation of that ion by biological activity or cation exchange within the watershed.

As in precipitation, sulfate was the dominant anion in stream water and represented 64 percent of the total anion concentration by equivalents. Nitrate accounted for 22 percent of the total anions, and chloride 9 percent. Bicarbonate concentrations were generally low but increased to as much as 15 percent of total anions at base flow.

Average volume-weighted $\mathrm{pH}$ as determined from hydrogen-ion concentration of Biscuit Brook water over the 2-year study was 5.24. Base-flow pH ranged from 6.0 to 6.5 during all seasons except spring, when it decreased below 6.0. The lowest $\mathrm{pH}$ measured, 4.89, was during peak flow on April 5, 1984. Average volume-weighted alkalinity for the study was $17 \mu \mathrm{eq} / \mathrm{L}$, and individual sample values obtained by Gran's plot titration ranged from $55 \mu \mathrm{eq} / \mathrm{L}$ to $-12 \mu \mathrm{eq} / \mathrm{L}$.

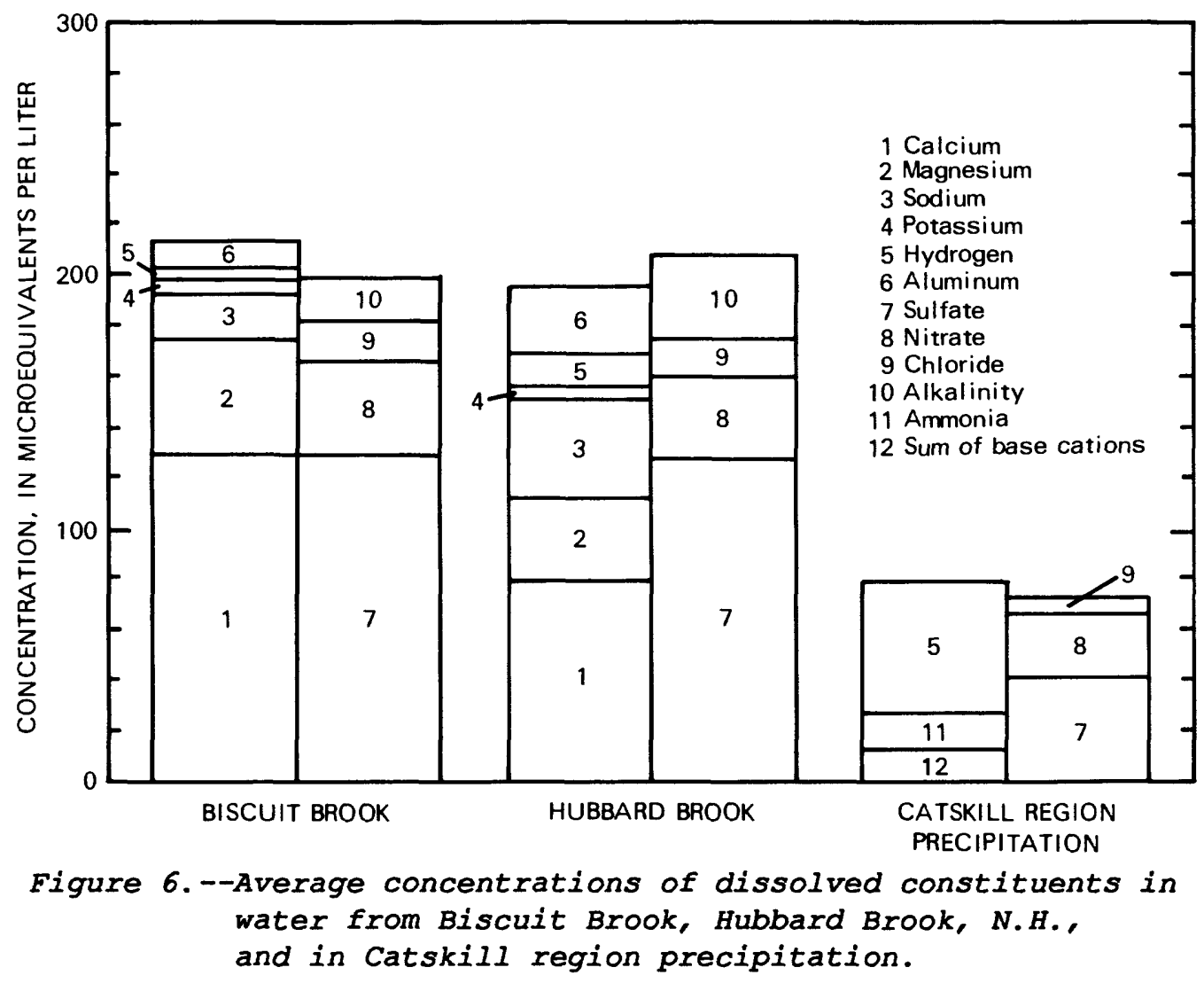

\section{Seasonal Fluctuations}

Fluctuations in constituent concentrations during any month were as great as those from month to month as a result of the highly variable stream discharge. Some seasonal trends are evident, however (appendixes A, B). Specific conductance had two peak periods each year (February and November), 
which indicates greater-than-average concentrations of ions during those months. The lowest specific conductance values were recorded in the spring, the time of high flow and snowmelt. The spring melt caused dilution of all constituents except nitrate, potassium, aluminum, and hydrogen ion, which increased with increasing flow. Peak nitrate concentrations for both years $(92 \mu \mathrm{eq} / \mathrm{L})$ occurred during snowmelt. Above-average concentrations of all constituents except nitrate and hydrogen also occured during November of both years. These elevated concentrations parallel higher-than-average concentrations of dissolved organic carbon, which suggests the release of nutrients from biolog-ical sinks, most probably fallen leaves. The alkalinity was elevated during November of both years, whereas pH remained within the base-flow range of 6.0 to 6.5 . The increased chloride concentrations in the fall suggest seasonal storage and release of chloride in the watershed. Chloride deposition from precipitation did not increase during the fall of either year. Sulfate and nitrate deposition increased substantially during July through September of WY85 and may account for some of the increased fall concentrations in the stream water.

\section{Comparison with Other Streams in the Catskills}

A comparison of volume-weighted mean concentrations of major constituents of Biscuit Brook and six nearby streams shows that the primary chemical difference between these streams is calcium concentration and alkalinity; higher alkalinity occurs in streams with high calcium (table 6). Hollow Tree Brook in the Esopus River basin (fig. 7) had higher concentrations of all constituents than the other streams, which suggests greater chemical interaction between basin materials and precipitation. Woodland Creek had slightly higher magnesium concentrations than the other streams; otherwise, concentrations of magnesium, sodium, and potassium were fairly uniform among the streams studied. Concentrations of sulfate, nitrate, chloride, and ammonium also were nearly the same in all streams except Hollow Tree Brook, which suggests either uniform dissemination of these species throughout the Catskill soils and bedrock, or that precipitation is the primary source of these constituents. Concentrations in Biscuit Brook were near the middle of the range observed in the other streams; therefore Biscuit Brook chemistry was considered representative of that in other streams of the Catskill region.

\section{Comparison with Surface Waters Outside the Catskills}

Comparison of chemical concentrations in Biscuit Brook with those in other streams of the Northeast that have longer periods of record shows a large similarity of anion concentrations but a dissimilarity of calcium and magnesium values (Driscoll and Newton, 1985; Likens and others, 1977). The average anion concentrations in the Catskill streams are similar to those at Hubbard Brook, N.H., where a long period of record indicates sulfate and nitrate in stream water to be derived primarily from atmospheric sources (Likens and others, 1977) (table 6). The percentage of total anions accounted for by sulfate and nitrate in the two streams is similar (fig. 6), but the sum of base cations at Biscuit Brook was greater than at Hubbard Brook, and aluminum concentrations at Biscuit Brook were lower. Also, the ratio of calcium and magnesium to sodium and potassium at Biscuit Brook was greater than at Hubbard Brook, primarily because Hubbard Brook has much higher sodium concentrations than the Catskill streams. 
A comparison of ion concentrations in Biscuit Brook with those in several Adirondack lake outlets yields similar results. Nitrate and sulfate concenations in both areas had similar ranges, and base-cation and alkalinity values in both were highly varied (Driscoll and Newton, 1985). In contrast, streams in the Shenandoah National Park, Va., had lower sulfate and nitrate concentrations, possibly as a result of greater sulfate absorption in the soils (Lynch

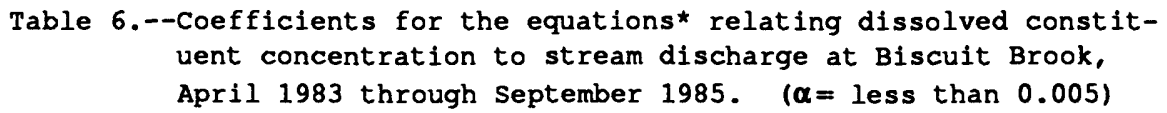

[Concentrations are in microequivalents per liter; a dash indicates the coefficient was not determined]

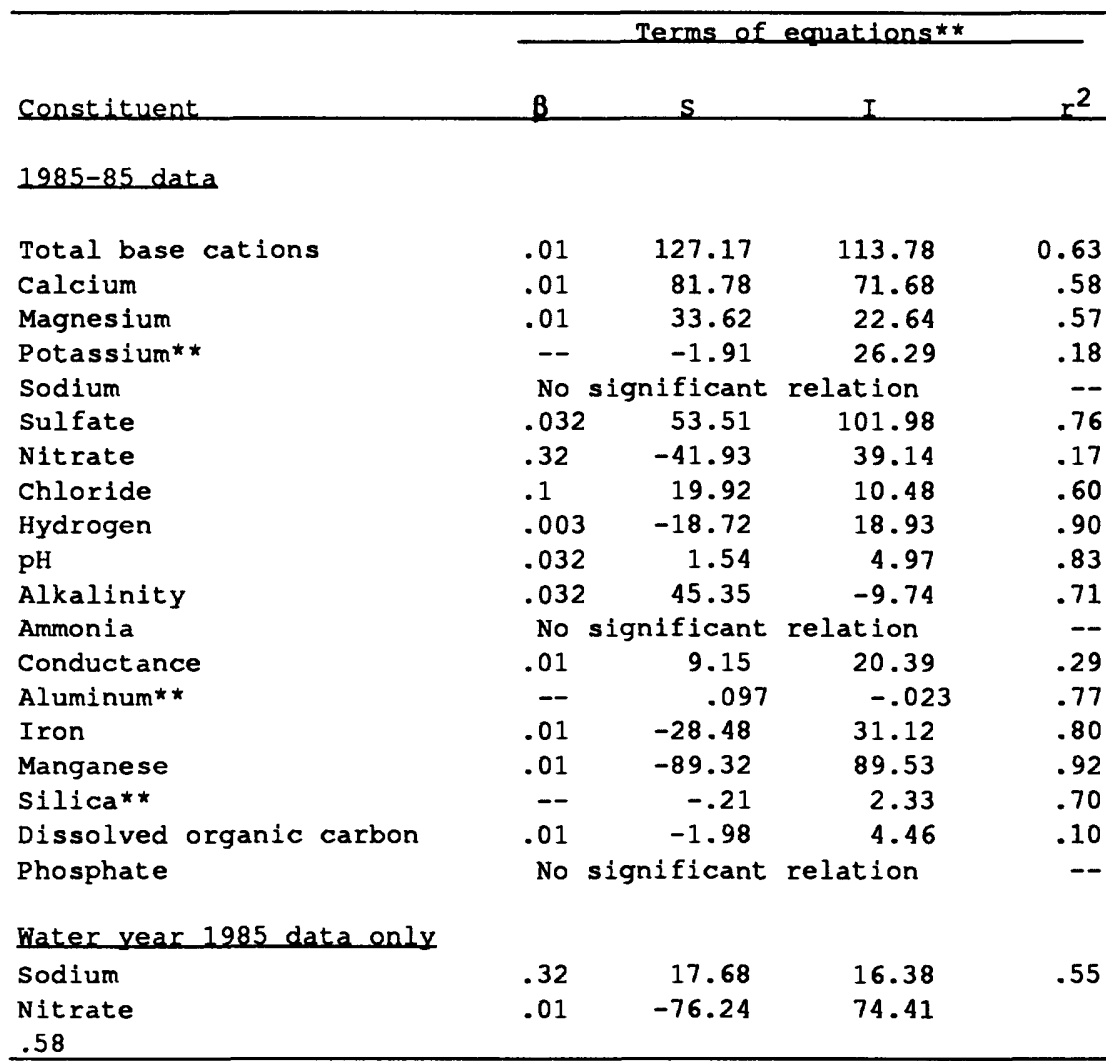

* Model equation: Concentration $=\frac{1}{1+b D} S+I ?$

** Model equation: Concentration $=\log D(S)+I$

where: $\beta=$ beta, a constant,

$D=$ instantaneous stream discharge, in cubic feet per second,

$S=$ slope of the concentration-vs-discharge relation,

$I=y$ intercept of the concentration-vs-discharge relation,

$\alpha=$ confidence limits, and

$r^{2}=$ proportion of the total variance in concentration explained by the regression model (coefficient of determination).

(From Johnson and others, 1969) 
and Dise, 1985). These comparisons suggest that surface waters of the northeastern U.S. have significant similarities and that the primary differences both among the Catskill streams and between Catskill streams and others in the Northeast are in the base-cation concentrations.

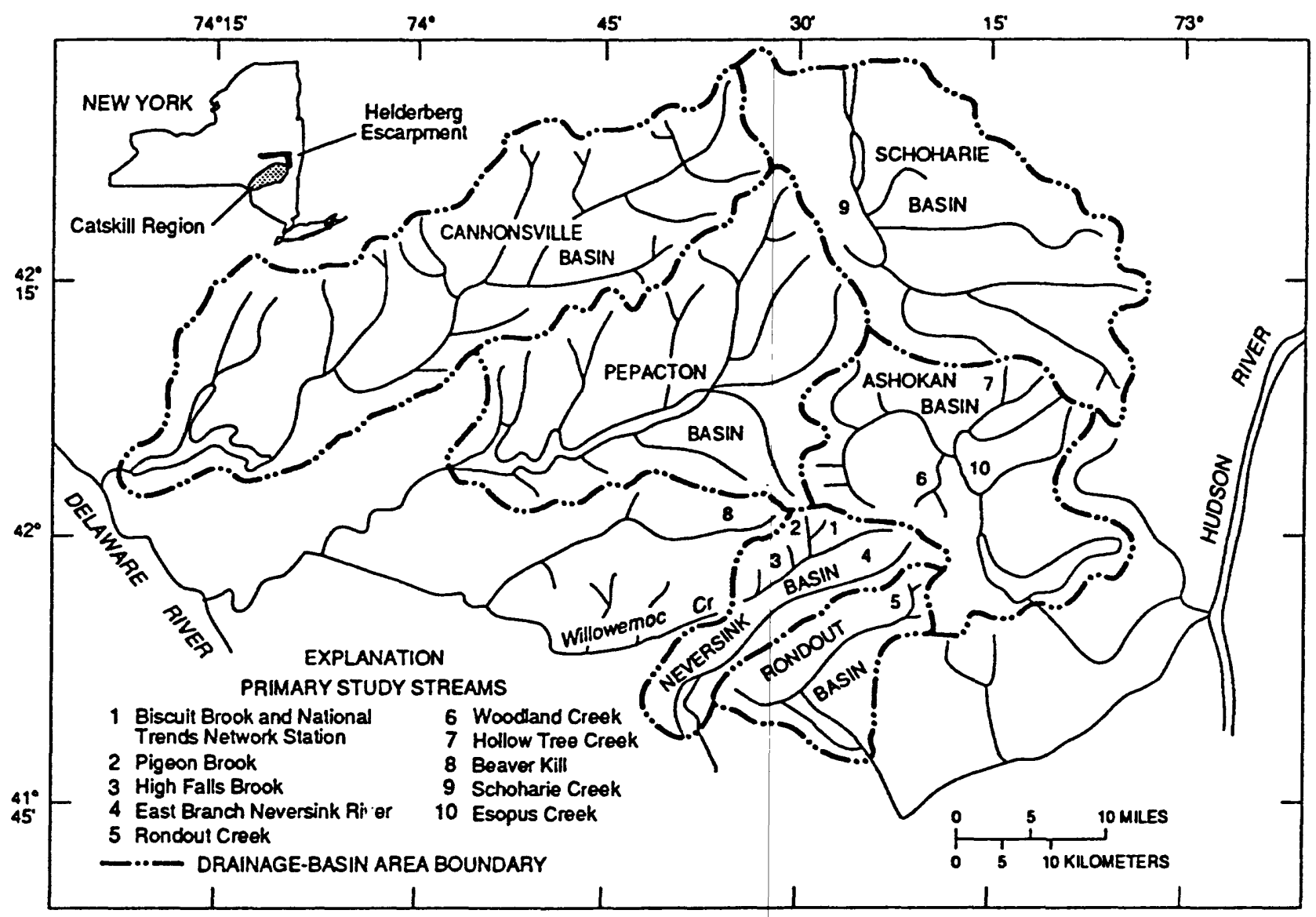

Base from U.S. Geological Survey, State base map, 1974

Figure 7.--Location of stream basins studied, 1983-85.

\section{Daily Stream Concentrations and Yields}

Results of regression analyses suggest that reasonable estimates of daily concentrations of all major constituents except potassium, sodium, and nitrate can be derived from the relations between concentration and discharge (table $6)$; the daily concentrations of the latter were obtained through graphic interpolation between sampling dates. The significance of the $r^{2}$ (coefficient of determination) value in the regression analyses is related to the number of observations; therefore, at specified confidence limits, the needed $r^{2}$ value decreases as the number of observations increases. All concentrations estimated from discharge data were found to be significant at the 99.5-percent confidence limit through a t-test for each. 
Significant $\mathrm{r}^{2}$ values for sodium and nitrate could be generated only from the WY85 data in the regression analysis, and the water-budget yields of nitrate that were derived from these calculated concentrations were 27 percent higher than those based on estimates obtained by graphic interpolation (table 7). The two methods produced similar results from october to May, but biological activity during the summer months altered the relation between concentration and discharge (fig. 8). Comparison of chloride values obtained by the two methods shows a 9-percent discrepancy, which is well within the measurement error. This difference occurs only in the May-to-october data and may therefore also be due to the effects of biological activity. Potassium yields based on concentrations estimated by the two methods differed by 76 percent; here the regression method substantially overestimated the concentration. The regression must therefore be used carefully in calculations for constituent concentrations affected by biological activity. Some error in graphic interpolation of the data may have also contributed to the disparity.

All yield values reported in the wY85 chemical budgets, except those for nitrate, potassium, and chloride, were generated from daily concentrations obtained through regression analysis; values for the latter three were generated from concentrations obtained through graphic interpolation. All yield values for the WY84 budgets were also generated from the regression equations, but nitrate, potassium, and chloride values were adjusted by the ratio of the graphic-interpolation values to the regression values for WY85.

The regression analysis indicated no significant relations between discharge and ammonium, phosphate, or dissolved organic carbon. The relation between aluminum concentration and the logarithm of discharge for all flows has an $r^{2}$ value of 0.80 . The best-fit relation between constituent concentrations and stream discharge were curvilinear except those for potassium, aluminum, and silica, which were log linear. Additional discussions of the relation between discharge and stream chemistry are given in the analysis of individual storms in a later section.

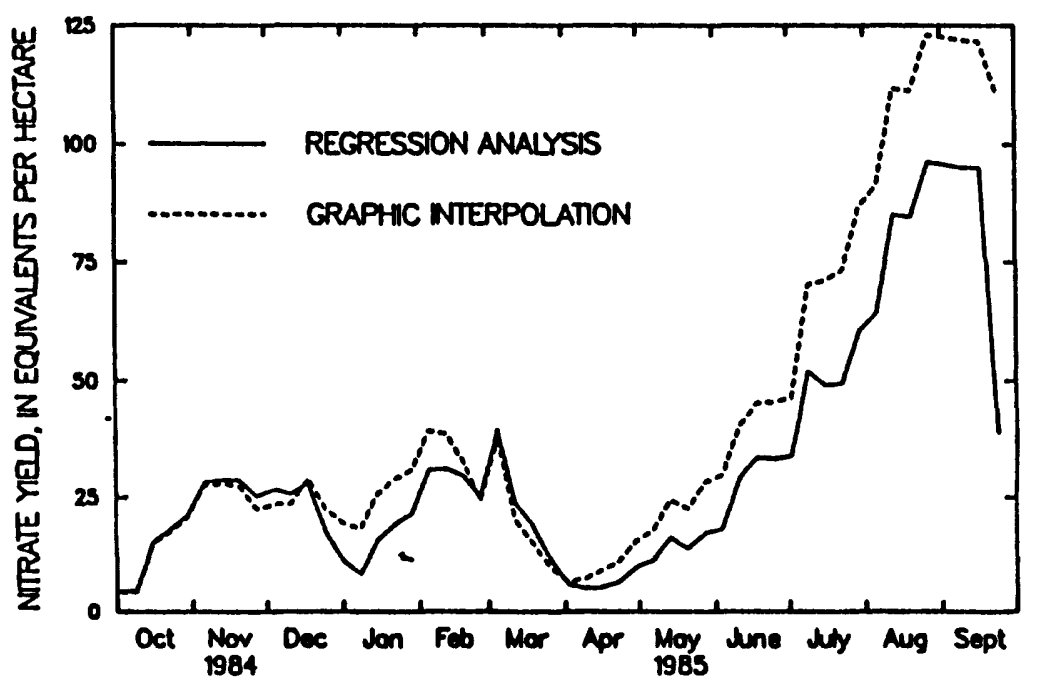

Figure 8.

Cumulative yield of nitrate in Biscuit Brook, water year 1985, computed by regression and graphic interpolation methods. 
Table 7. Comparison of annual nitrate, chloride, and potassium yields based on daily concentrations calculated through graphic interpolation and regression analysis of water year 1985 data for Biscuit Brook.

[Values are in equivalents per hectare]

\begin{tabular}{lccc}
\hline Constituent & $\begin{array}{c}\text { Graphic interpolation } \\
\text { yield }\end{array}$ & $\begin{array}{c}\text { Regression analysis } \\
\text { yield }\end{array}$ \\
\hline & & & \\
Nitrate & 191.0 & 256.2 & 0.58 \\
Chloride & 113.1 & 124.9 & 0.60 \\
Potassium & 35.1 & 149.8 & 0.18 \\
\hline
\end{tabular}

\section{CHEMICAL BUDGETS}

The chemical budgets for WY 84 and WY85 suggest a net loss of base cations, sulfate, chloride, and alkalinity from the watershed during both years, and a net accumulation of nitrate, ammonia, and hydrogen ion (table 8, fig. 9). Anion-to-cation ratios in both precipitation and stream-water samples for both years were well within 10 percent of unity. Some of the apparent net losses may be due to the omission of a dry-deposition component in the precipitation calculations. (Dry-deposition monitoring was suspended at Biscuit Brook because the dry-bucket method was found to be inaccurate.) Estimates of dry deposition at West Point, N.Y., $80 \mathrm{~km}$ to the southeast, suggest that between 10 and 20 percent of the anion loads and up to 60 percent of the cation loads during 1980-84 may have been derived from dry deposition (Richard Semonin, National Atmospheric Deposition Program, oral commun., 1986). Other estimates of strong-acid anion deposition in dryfall in the Northeast are much higher (Galloway and others, 1983). Therefore, some part of the total loading may have been omitted during the Biscuit Brook study. Interpretation of the chemical budgets for individual constituents follows, and potential sources, sinks, and measurement errors are discussed with each.
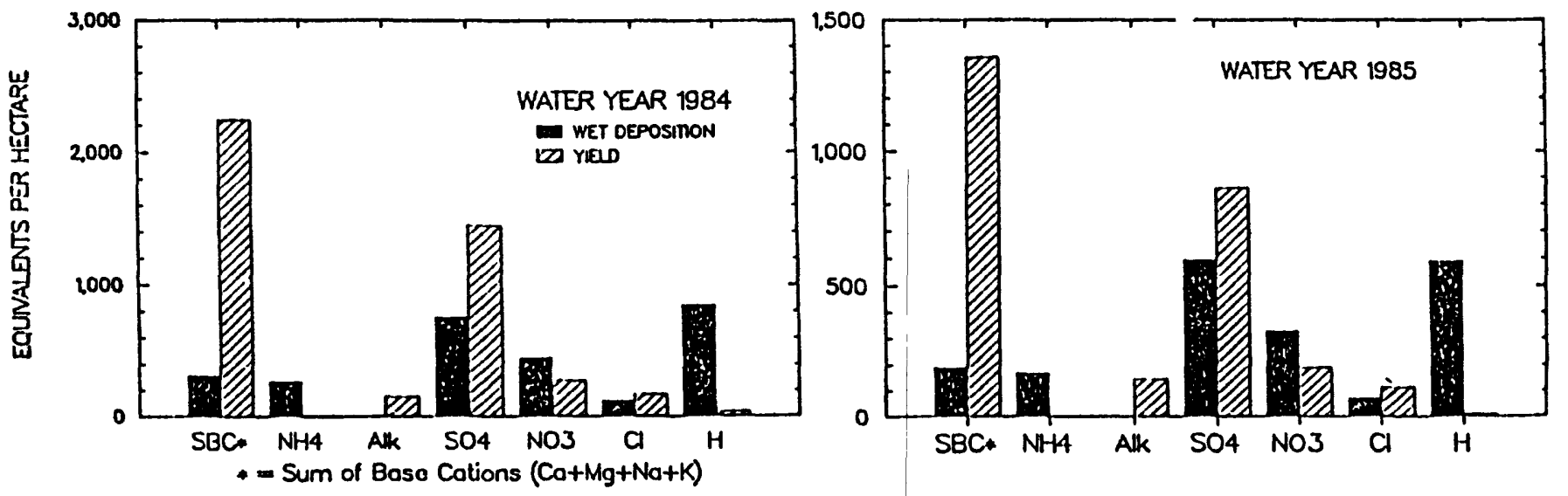

Figure 9.--Chemical inputs (deposition) from precipitation and outputs (yield) in stream water at Biscuit Brook, water years 1984-85. 


\section{Chlorlde}

The Biscuit Brook watershed showed a net loss of chloride during both water years observed (table 8 ). Chloride from wet precipitation made up 78 percent of the stream's chloride yield in WY84 and 61 percent in WY85. Thus, if chloride deposition and yield estimates are correct, one-quarter to onethird of the calculated chloride yield is due to error or is from sources other than wet deposition. Possible explanations of this apparent net loss are (1) overestimation of chloride yield, (2) unmeasured chloride in dry deposition, (3) weathering of chloride-bearing minerals, (4) dissolution of soil precipitates within the watershed, (5) ion exchange, and (6) measurement error.

Errors inherent in the estimates of yields obtained from concentration derived through regression analysis and the graphic method could be large and, when combined with errors in precipitation measurement and input calculations, could explain the larger yield. The $r^{2}$ value for chloride indicates a close correlation between chloride concentration and stream discharge, however, and also was similar to $\mathrm{r}^{2}$ values found by other researchers (Feller and Kimmins, 1979; N. E. Peters, U.S. Geological Survey, oral commun., 1986). The regression results differed from graphic-method results by less than 9 percent (table 7 and fig. 10). Applying estimates of chloride in dry deposition at West Point, N.Y. (16.5 percent of total chloride deposition during 1984) to Biscuit Brook would increase total annual chloride deposition to $160 \mathrm{eq} / \mathrm{ha}, 94$ percent of the stream's chloride yield (Richard Semonin, National Acidic Deposition Program, oral commun., 1986). (See table 8.) Dry deposition during an exceptionally dry period such as occurred in both WY84 and WY 85 could contribute a larger percentage of the total chloride load than it would otherwise. Salt aerosols from ocean spray have been shown to travel far inland in some areas (Junge and Werby, 1958). Also, chloride-bearing dust generated by traffic over heavily salted roads in the region may be transmitted by wind into the watershed. If typical estimates of the sulfate contribution to dryfall (30 percent) are applied to chloride, not only would all excess chloride in the budget be attributed to dry deposition, but a net chloride retention would be indicated.

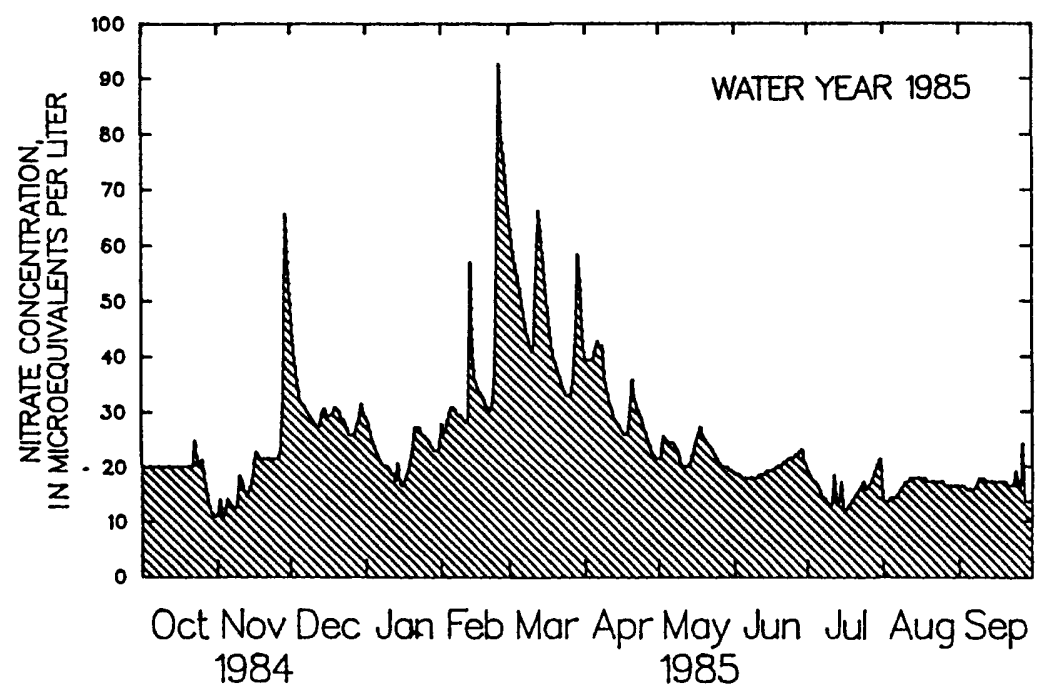

Figure 10.

Nitrate concentrations in Biscuit Brook, water year 1985 . 


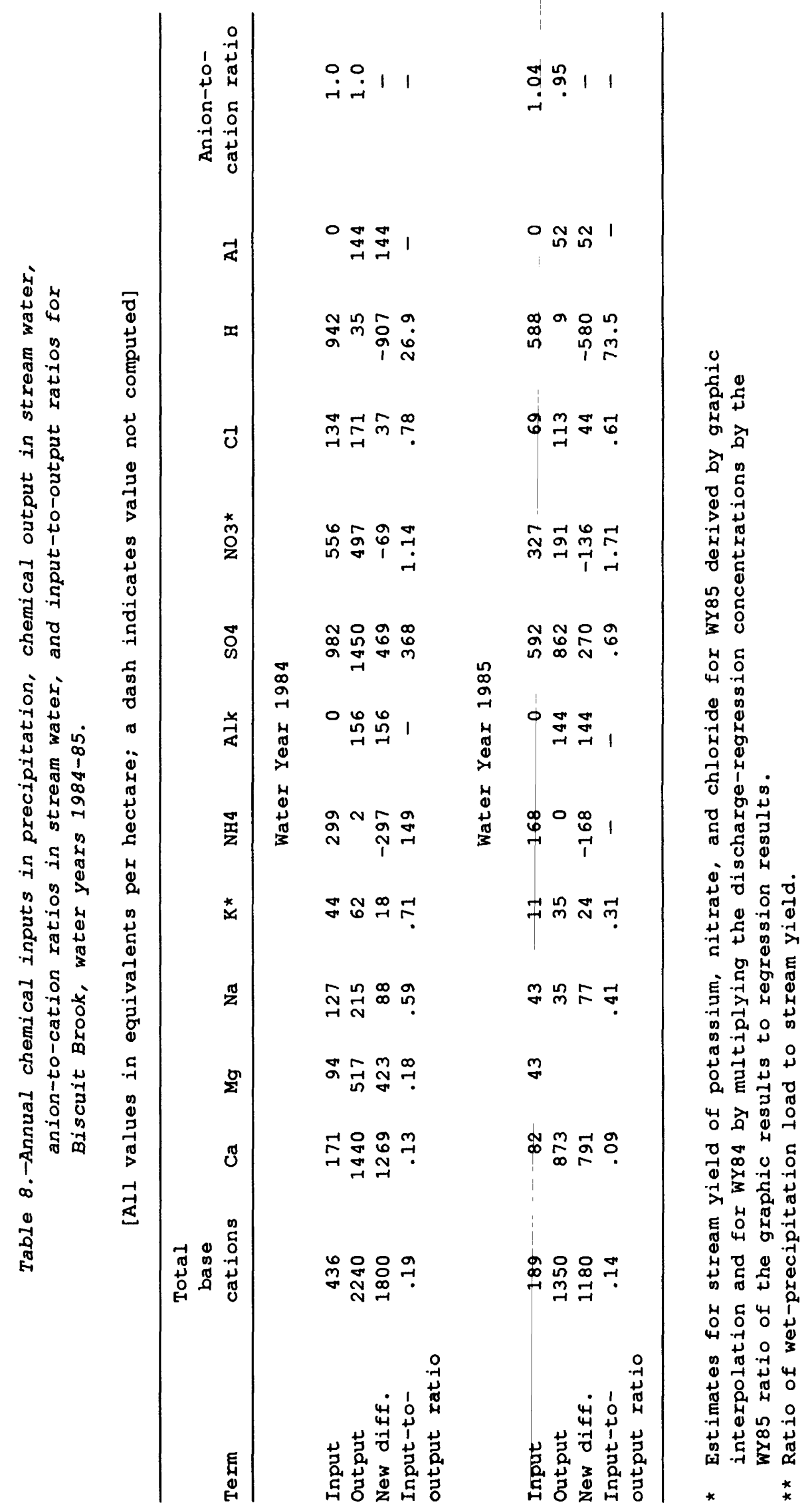


Another source of chloride within the watershed may be the bedrock and till, although bedrock is strongly leached along joint fractures and bedding surfaces along which most of the ground water would flow (Way, 1972). Thus, deep ground water probably contributes little chloride to the stream. The ratio of sodium to chloride in the stream is about $1: 1$, which indicates salt to be the primary source. Also, chloride from previous deposition may be stored in the upper soil horizons as a result of evapotranspiration; chloride concentrations show a 66-percent decrease with increased discharge up to 4 $\mathrm{m}^{3} / \mathrm{s}$, which could be explained by a washout of stored chloride from the soil zone. At discharges greater than $4.2 \mathrm{~m}^{3} / \mathrm{s}$, the chloride concentration remains stable at $10 \mu \mathrm{eq} / \mathrm{L}$.

In an effort to identify chloride sources, several springs in the Biscuit Brook watershed and one well that taps bedrock near the mouth of the brook were sampled in May 1986. Although the data are few, they can be used to assess the potential of ground water as a source of chloride. Water from the bedrock well contained a moderate chloride concentration $(79 \mu \mathrm{eq} / \mathrm{L})$. Thus, if annual concentrations in the stream reflect mixing of precipitation with this ground water, 92 percent of the stream water would have to be derived from direct unaltered precipitation and 8 percent from ground water.

Water samples from springs within the watershed during base flow contained substantially lower chloride concentrations $(15 \mu \mathrm{eq} / \mathrm{L})$ than water from bedrock. If precipitation and spring water were mixed to create the observed stream chemistry, 40 percent of the stream water would be derived from direct precipitation and 60 percent from shallow soil water. This result is consistent with findings in the Mattole River basin in California, which were based on chloride and oxygen-isotope data and indicated deep ground water to be an insignificant component in stream chemistry (Kennedy and others, 1986). The lack of observed overland runoff in the Biscuit Brook watershed, even during large storms, indicates that nearly all precipitation infiltrates to at least a shallow flow system, where it mixes with and dilutes the soil water. Chloride concentrations in the stream during individual storms can be closely predicted from the above percentages. If the chemical composition of spring water is assumed to be constant, this suggests that the mixture of precipitation with soil water and its transport along the shallow flow paths are rapid.

The 40:60 ratio of precipitation to soil water also appears to be correct when used to estimate average concentrations of the other anions. The stream's sulfate concentration predicted by this ratio is 86 percent of the flow-weighted annual average concentration calculated for the stream, and the predicted nitrate concentration is within 1 percent of the measured annual value. The comparison indicates that stream-water chloride in Biscuit Brook probably is derived mainly from precipitation and the shallow soil.

\section{Nitrate}

The chemical budget indicates a net retention of nitrate in the watershed during both years of the study. The annual input-to-output ratio for nitrate in WY85 was 1.71 , which indicates significant retention and is similar to the ratio calculated for the outlets of the two pristine lake in the Adirondack Mountains during 1978-80 (Galloway and others, 1983). The ratios for 
nitrogen, calculated from measured concentrations in wetfall and in the stream, actually are minimum estimates because they do not represent contributions from dryfall, gaseous nitrogen, or ammonium. If ammonium is included in the total nitrogen input load, the input-to-output ratio increases to 1.73 for WY84 and 2.59 for WY85. As at Hubbard Brook, the calculated amount of nitrate and ammonia retained in the watershed probably does not represent the total accumulation of nitrogen compounds in the biomass; therefore, some additional unmeasured nitrogen probably enters the watershed as dry deposition (Likens and others, 1977). Nitrification could also take place in forest soils and in some reaches of Biscuit Brook that were ponded by debris or beaver dams, except that stormflow usually eliminates these obstructions during the same season in which they are built. Thus, low yield relative to deposition probably indicates biological uptake of nitrogen in the watershed. The WY85 net yield of nitrogen showed a seasonal pattern similar to that observed in Adirondack lake outlets (Galloway and others, 1983), with net accumulation during the summer and fall, net loss during snowmelt periods, and balanced inputs and outputs during winter (fig. 8). Nitrate yields in the stream remained lower during midwinter than was calculated from the discharge regression as a result of storage in the snowpack and either a lack of flow through the shallow soil horizons or biological uptake in the soil.

Streamflow in Biscuit Brook was greater during WY 84 than in WY85, which caused a greater apparent net yield of nitrate during WY84.

The most significant aspect of the nitrate budget is the large yield during spring snowmelt (fig. 10). The occurrence of the spring "pulse" is consistent with results from the Adirondacks and Hubbard Brook, N.H., but is contrary to the results at Bickford Reservoir in Massachusetts, where stream nitrate concentrations remained low $(1 \mu \mathrm{eq} / \mathrm{L})$ through the spring (Hemond and Eshleman, 1984). The annual wet deposition of nitrate at Biscuit Brook (441 eq/ha) appears slightly greater than at the other watersheds (Bickford Reservoir, 295 eq/ha; Hubbard Brook 317 eq/ha).

Most of the ammonia received from atmospheric loading in the Biscuit Brook watershed is retained as in other watersheds being studied in the Northeast (Hemond and Eshleman, 1984). Although Biscuit Brook is farther south than Bickford Reservoir, it has both a higher elevation and greater relief; therefore biological demand could be somewhat less. Nitrate retention at Biscuit Brook is less than at Bickford Reservoir, which is consistent with the rate of nitrate release in the other major mountain regions of the Northeast.

\section{Sulfate}

Sulfate yields in Biscuit Brook exceeded sulfate deposition in wet precipitation in both WY84 and WY85 (figs. 9, 11). Sulfate from wet precipitation accounted for 68 percent of the stream's sulfate yield in WY84 and 69 percent in wY85. The greatest net loss of sulfate occurred from December through May of both water years, with a slight accumulation of sulfate during the late summer months (fig. 11). Possible reasons for the large yield of sulfate are the same as for chloride--overestimation of stream yield by the regression equations, significant dry deposition of sulfate, and natural sources of sulfate within the watershed. The close correlation between sulfate concentration and stream discharge indicate that the regression analysis was a fairly accurate assessment of net sulfate yield, however (table 6). 
A sulfate source within the watershed may be due to the presence of sulfur-bearing minerals in the bedrock of other areas around the Catskills (Way, 1972). Pyrite has been observed in bedrock outcrops $35 \mathrm{~km}$ east and south of the study area in association with coal (Way, 1972) but has not been observed in the Biscuit Brook watershed. As the previous discussion of chloride explains, however, bedrock is probably not a major contributor to surface-water chemistry. The sulfate concentration of water from the bedrock

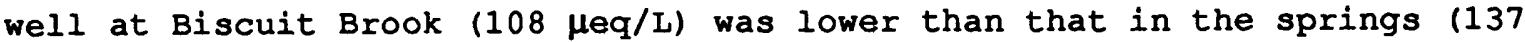
$\mu e q / L)$, which suggests either storage of atmospheric sulfate in the surface materials or that sulfate was transported into the basin in the till. Bedrock sources of sulfate are therefore probably not a significant factor in the sulfate budget for Biscuit Brook.

Dry deposition of sulfate and other sulfur compounds could be a major contributor to the apparent net yield of sulfate from Biscuit Brook. Influx of unmeasured sulfur compounds such as atmospheric $\mathrm{SO}_{2}$ to the oxidizing environment of aerated stream water can contribute to stream sulfate concentrations after it is metabolized by plants and animals in the watershed (Likens and others, 1977). Estimates of sulfur deposition in dryfall ranged from 17 to 60 percent of the annual deposition in the Northeast (Richard Semonin, National Atmospheric Deposition Program, 1986, oral commun.; Galloway and Whelpdale, 1980; Eaton and others, 1980; and Galloway and others, 1983). If the 30-percent value for sulfate deposition in dryfall commonly used for the Northeast is applied to the Biscuit Brook sulfate budget, the ratio of total deposition to yield would be 0.97 for WY84 and 0.98 for WY85. The lower observed ratio of 0.68 for Biscuit Brook is similar to that at Hubbard Brook (0.71), Panther Lake in the Adirondacks (0.77), and Birkenes in Norway (0.63), all of which have similar stream-sulfate concentrations and have had weathering discounted as a significant sulfate source (Hemond and Eshleman, 1984).

Comparison of volume-weighted average concentrations of sulfate in seven streams near Biscuit Brook indicates extremely uniform sulfate concentrations across the Catskill region (table 5). The average flow-weighted concentration of sulfate for all sites excluding Biscuit Brook was $124 \mu \mathrm{eq} / \mathrm{L}$, and was 133 $\mu e q / L$ for Biscuit Brook. Sulfide minerals such as pyrite are probably not distributed evenly within the Catskill geologic facies (Ethridge, 1977; Way, 1972; Woodrow, 1985), but the deposition rate of sulfate is probably relatively uniform throughout the region. Additional data on sulfate in ground water and soil water at Biscuit Brook and the other streams would be needed to completely identify the sources of sulfate in Catskill streams.

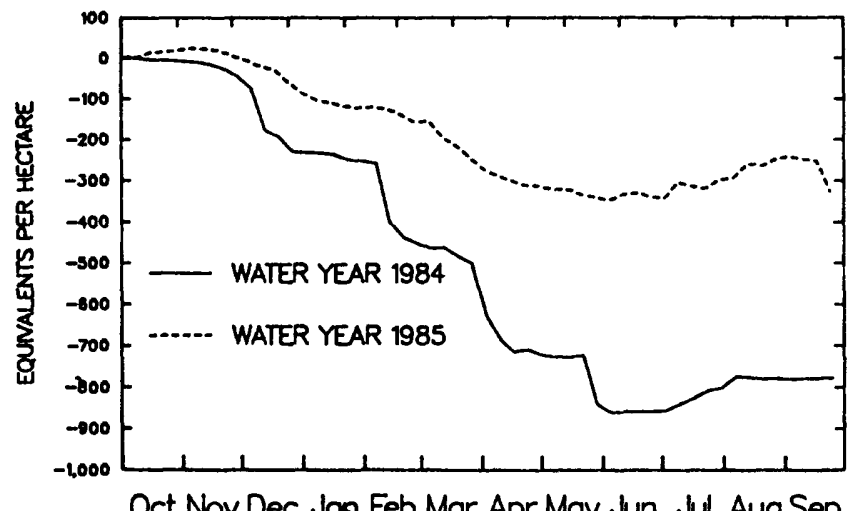

Figure 11.

Differences between sulfate input (wet deposition) and output (stream yield) in the Biscuit Brook watershed, water years $1984-85$. 


\section{Base Cations and Hydrogen}

A large net loss of base cations is indicated for both WY 84 and WY85 (fig. 12A). The cumulative chemical budget for WY84 reflects the episodic nature of stream cation yields during that year as a direct response to large storms. The $r^{2}$ value for the concentration-to-discharge relations suggests that 63 percent of the variability in base-cation concentration is a function of discharge (table 6); thus, the greater net loss during WY84 than in WY85 is a direct result of the greater discharge during wY 84 .

The chemical budget for hydrogen shows that acidity in precipitation is almost completely neutralized by the watershed (figs. 9, 12B). The ratio of hydrogen-ion deposition to stream yield increased gradually from December through July in water year 1984, and from April through July in water year 1985. This difference between years was caused by a lack of snowpack accumulation during water year 1985. From August through November of both years, depositon of hydrogen ion also exceeded stream yields but the rate of hydrogen release to the stream from the watershed was greater than during other periods of the year. Generally, the monthly rate of deposition relative to that of stream yield parallels the relative rates of precipitation and stream discharge.

Base-cation concentrations and yields are the primary factors that distinguish Biscuit Brook from other Catskill streams as well as from the Adirondack lake outlets and Hubbard Brook, N.H. Anion concentrations are similar among the streams mentioned; thus the differences in the streams' buffering capacities are related to the differences in base-cation concentrations. The Adirondack lakes and Hubbard Brook are on a different, more varied type of bedrock than the Catskill streams and, because the till that covers all three regions is derived mostly from local sources, the surficial materials should also differ. Yet, streams within these areas of the Northeast have major chemical similarities, which suggests that their water chemistry may be controlled by similar processes. The data suggest that if the basins contain surficial materials that are chemically different but equally nonreactive, the residence time of water within the materials may have a greater effect than the mineral composition on stream chemistry. Rapid flow
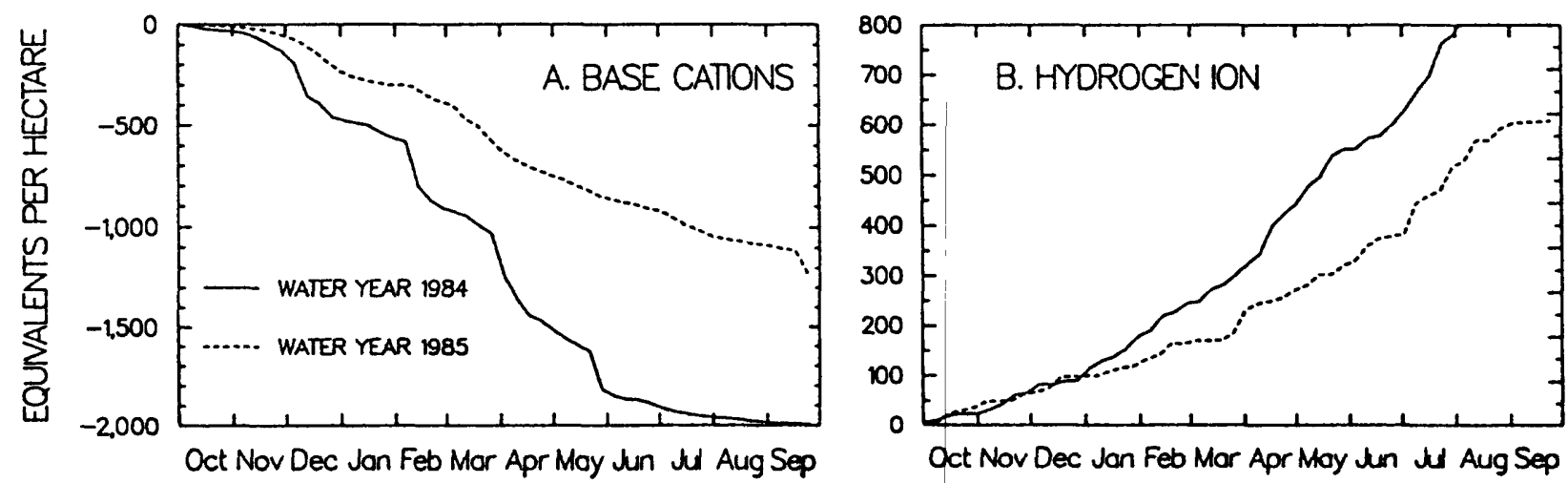

Figure 12.--Cumulative yield of total base cations and hydrogen ion in the Biscuit Brook watershed, water years 1984-85. 
through the watershed along shallow flow paths, as suggested by the analysis of spring-water chemistry, may also diminish the effect of mineralogical differences among basins. The differences in base-cation concentrations among Catskill streams, therefore, may be less related to local differences in carbonate content of the basins than to differences in the thickness, permeability, or transmissivity of the surficial materials.

\section{CHANGES IN STREAM CHEMISTRY DURING STORMS}

\section{General Trends}

Stream discharge and chemistry were frequently monitored during 14 storms and snowmelt periods between April 1983 and May 1986. Peak flows ranged from 0.17 to $22.7 \mathrm{~m}^{3} / \mathrm{s}$ (table 9). Maximum stream acidity occurred at or near peak flows and ranged from 6.18 to 4.98 . The maximum observed change in $\mathrm{pH}$ was 1.71 units during Hurricane Gloria on September 27, 1985. Minimum alkalinity during the 14 high flows ranged from 34.0 to -12.0 ( $\mu$ eq/L net acidity) by Gran's plot calculation. A maximum observed decrease in alkalinity of 60 $\mu e q / L$ occurred during Hurricane Gloria.

The correlation between streamflow and precipitation volume during the storms improved with increasing volume but was poorly defined at low volumes because (1) snowmelt contributed to discharge during the spring, and (2) soilmoisture conditions, which affect the amount of precipitation reaching the stream, differed from storm to storm. At high flows, a strong correlation was noted between stream pH, alkalinity, and flow, and $\mathrm{pH}$ declined below 5.0 in an apparent direct relation to precipitation volume. Adding the antecedent soilmoisture term (precipitation in the 14 days preceding a storm) to the comparison of storm-precipitation volume with streamflow volume did not significantly improve the correlation between precipitation and flow. The hydrologic response of Biscuit Brook to precipitation volume does provide an index of stream sensitivity to acidification, however, as Lynch and others (1986) showed for a small stream in central Pennsylvania through use of predictive models based on 18 storms.

Comparison of precipitation $\mathrm{pH}$ with stream $\mathrm{pH}$ (table 9) shows that stream $\mathrm{pH}$ values decrease and become more similar to precipitation $\mathrm{pH}$ as peak flows increase, but significant buffering of precipitation occur in the watershed during most high flows. Precipitation $\mathrm{pH}$ and minimum stream $\mathrm{pH}$ were similar only during the large storm of April 3-6, 1984. Minimum stream pH during Hurricane Gloria (September 27-28, 1985) was actually lower than precipitation $\mathrm{pH}$, which indicates a net acidification of the rainwater by materials already in the watershed. Minimum stream pH during all other storms exceeded precipitation $\mathrm{pH}$, which indicates a net buffering of rainwater acidity. The correlations of $\mathrm{pH}$ and major dissolved constituents with stream discharge during selected storms are plotted in figure 13.

As observed in other stream studies, the percent change in flow during individual storms at Biscuit Brook was far greater than the percent changes in chemical concentrations (Kennedy and others, 1986; Likens and others, 1977). Stream water is also more concentrated and has different ionic ratios than precipitation, which further suggests that contact with watershed materials 


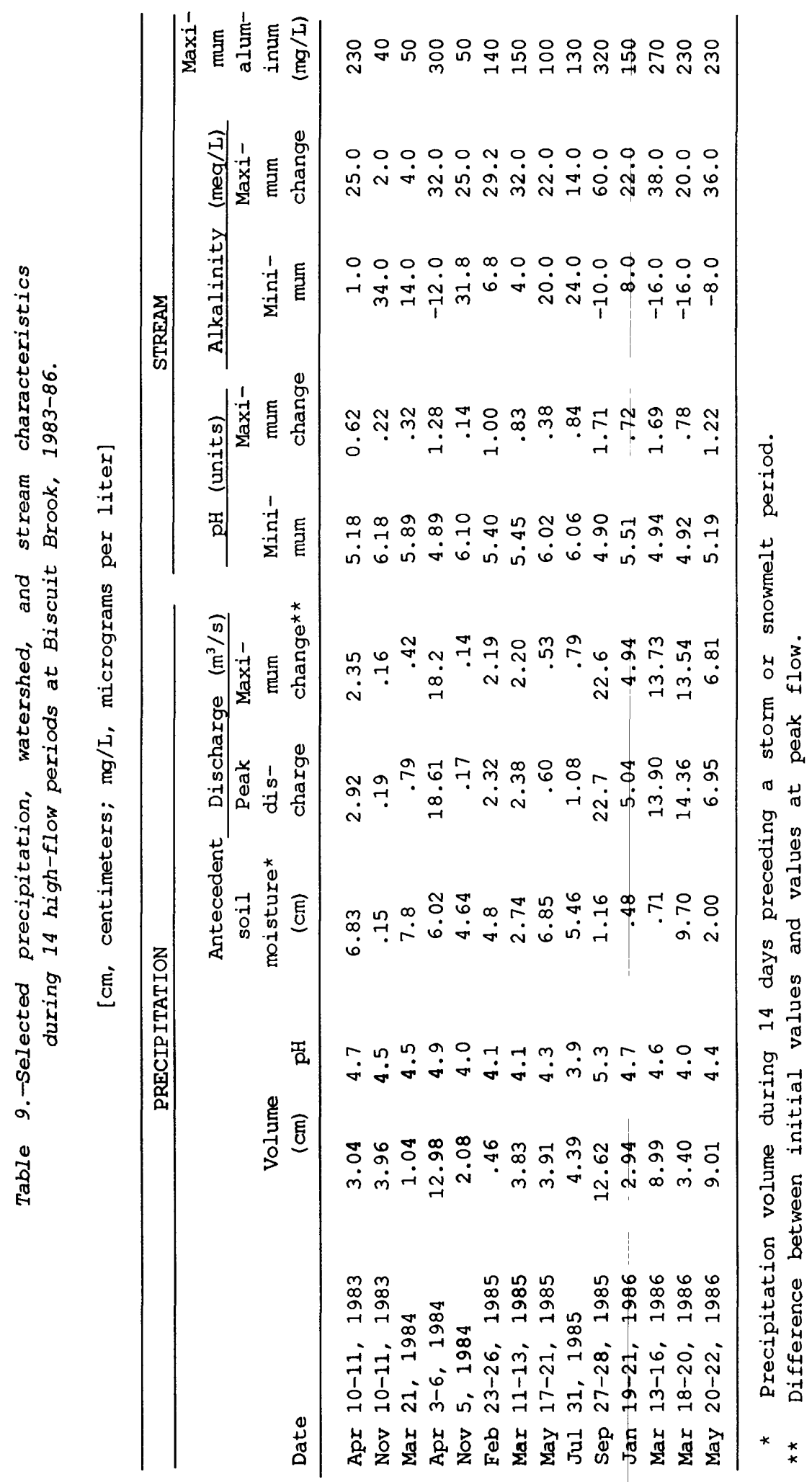


during each storm causes substantial changes in water chemistry (Kennedy and others, 1986). The resulting increase in net chemical yields during storms could have developed from two different processes--rapid dissolution of, or ion exchange with, chemical constituents in the shallow soil zone by rain before it reached the stream, and physical displacement of soil water and ground water to the stream by the hydraulic pressure of precipitation infiltrating the soil surface. Probably both process were acting to varying degrees during each storm to produce a complex relation between stream chemistry and discharge.

In general, results of the high-flow analyses show dilution of major cations, sulfate, chloride, and alkalinity during individual flow peaks and increased concentrations of hydrogen, nitrate, aluminum, and manganese.

Concentrations of minor constituents also changed during high flows. Potassium, a minor constituent of the total base cations, showed small increases with increased flow. Dissolved organic carbon increased with

A. APRIL 4-6. 1984

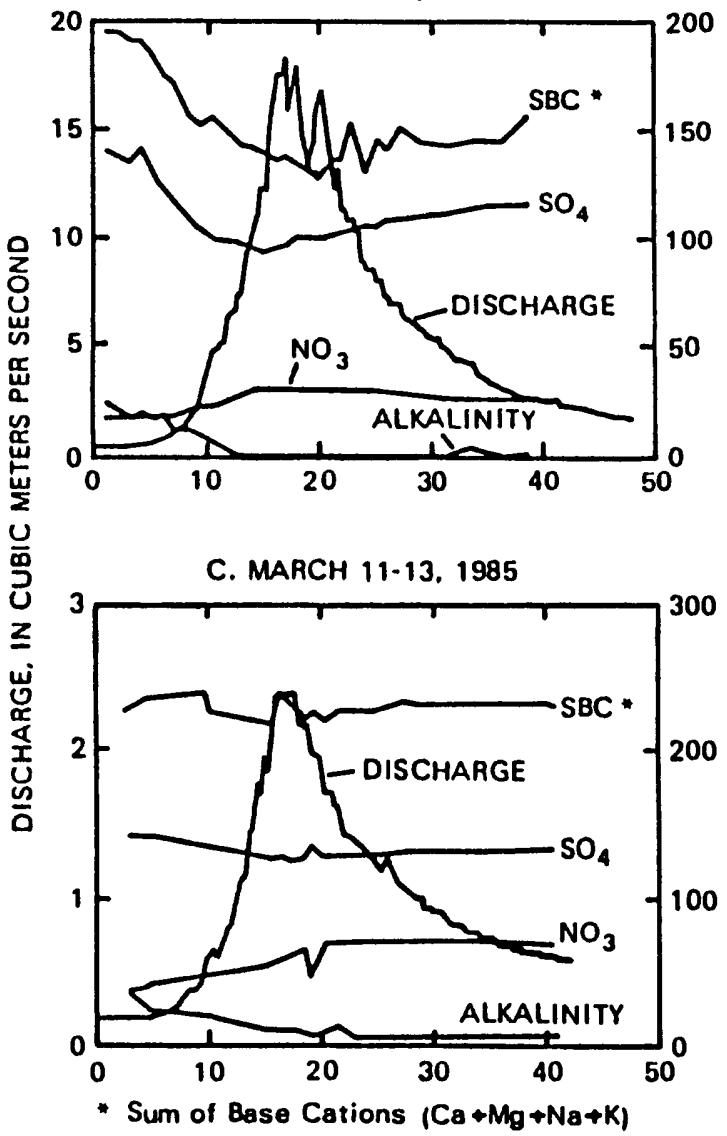

B. JULY 31-AUGUST 1, 1985

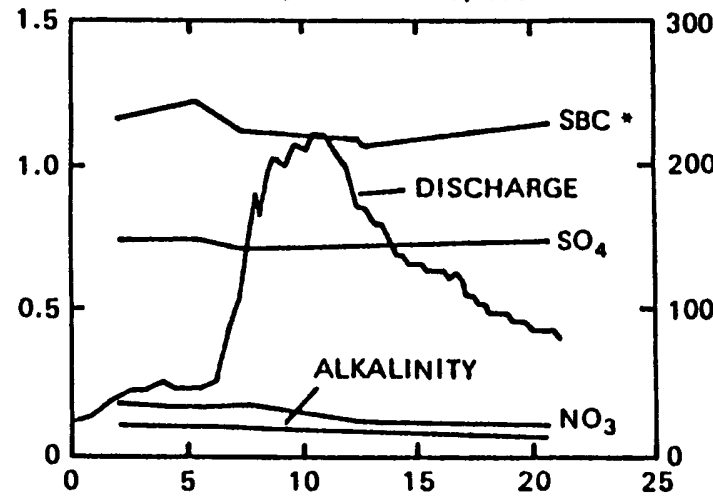

D. SEPTEMBER 27-28, 1985

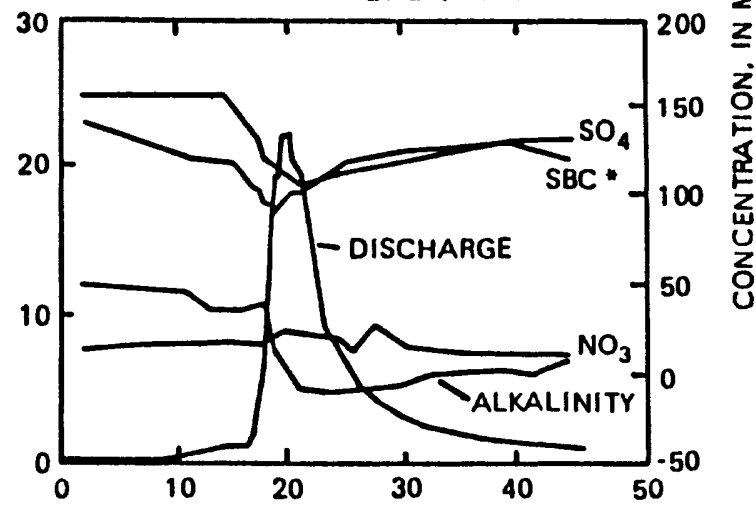

STORM DURATION. IN HOURS

Figure 13.--Response of alkalinity, total base cations, sulfate, and nitrate concentrations to discharge of Biscuit Brook during selected high flows. 
increasing flow, which suggests flow through the organic soil layer to the stream; this seepage may account for some of the observed stream $\mathrm{pH}$ decrease during storms.

The lowest $\mathrm{pH}$ values occurred slightly after peak flow except during Hurricane Gloria, when the lowest $\mathrm{pH}$ value coincided with the flow peak. The highest aluminum values occurred after the peak discharge in five of the nine storms but coincided with the flow peak during Hurricane Gloria and the storm of July 31, 1985. Silica decreased with increased flow, which indicates dilution of dissolved weathering products. The results of the stormflow analysis are thus consistent with the observed relations between chemical concentrations and flow described previously.

\section{Concentration Pulses}

Although the general trends described above are evident from the storm data, smooth changes in concentration did not occur during most storms as flow increased and receded. Rather, "pulses" of apparent increased concentration of some constituents occurred throughout the event. Most of these pulses can probably be attributed to variation in sampling and analytical quality. Some constituents show consistent patterns among the storms, however, which may indicate a flushing of solutions from different parts of the basin. The pulses show no seasonal trends. Pulses that precede flow peaks could be caused by soil-water extrusion or shallow-ground-water discharge in response to the hydrostatic pressure of the initial rain. Pulses during and after flow peaks could represent the delayed effect of variable storm intensity in upstream catchments but also could suggest flow through the upper soil zone, as evidenced by the increase in dissolved organic carbon and decreased silica concentrations with increasing flow.

Interpretation of concentration patterns during storms at Biscuit Brook would require monitoring of soil and ground water, which was beyond the scope of the study. The results suggest two possible controls on the chemical quality of Biscuit Brook, however--(1) chemical differences among source areas within the watershed, and (2) shallow-soil storage of deposited ions, including those from dry deposition.

\section{Nitrate}

Nitrate concentration showed large increases during the spring storms of WY84, WY85, and WY86 and small increases during storms of all other seasons except late summer; it also showed substantial increases during Hurricane Gloria in September 1985 (fig. 13D). Analyses of stormflow concentrations of nitrate at Biscuit Brook and of average nitrate concentrations at other Catskill streams suggest that biological activity does not take up all of the nitrate that is being delivered to the Catskill watersheds. Increased nitrate appeared in the streams even during storms late in the growing period. Nitrate retention in the watershed appears to be a significant mechanism for decreasing the yields in Catskill streams, but deposition of nitric acid also appears to be an important stream-acidifying agent during storms in the Catskill region. 


\section{Sulfate}

Sulfate concentrations decreased with increasing discharge during all storms of the study except that of November 4-5, 1984, in which discharge increased only slightly. During that storm, concentrations of all major constituents also increased, and all these increases were probably attributable to leaching of the leaf litter. During the other storms, concentrations of sulfate decreased at a slower rate than the concurrent dilution of base-cation concentrations, which indicates that sulfuric acid enters the stream at a more sustained rate than the weathering products during increasing flows. A similar relation between sulfate and base cations was observed in association with a net acidification of surface waters at three Adirondack lake outlets during the spring snowmelt (Galloway and others, 1986). Acidification of stream water during major storms in the Catskills is therefore probably a result of both an increase in concentrations of nitric acid and in the ratio of sulfate to base-cation concentrations with flow.

\section{Stream Acidification and Aluminum Mobiiity}

Several generalizations concerning acidification at Biscuit Brook can be proposed from the results of the storm observations. Plots of $\mathrm{pH}$ against the logarithm of discharge suggest that $\mathrm{pH}$ generally dropped below $5.0 \mathrm{pH}$ units when the flow exceeded $7.1 \mathrm{~m}^{3} / \mathrm{s}$ (fig. 14). The average threshold at which $\mathrm{pH}$ fell below 5.5 was approximately $1.8 \mathrm{~m}^{3} / \mathrm{s}$. Daily discharge exceeded $1.8 \mathrm{~m}^{3} / \mathrm{s}$ on 10 days during $W Y 84$ and on only 1 day during WY85. Instantaneous discharge exceeded $7.1 \mathrm{~m}^{3} / \mathrm{s}$ during four storms in WY84 and one in WY85. Thus, "episodes" in which $\mathrm{pH}$ was below 5.0 occurred at least annually at Biscuit Brook during the study, and episodes below pH 5.5 occurred several times.

The relation between alkalinity and the logarithm of discharge indicates that zero alkalinity occurred at flows as low as $2.3 \mathrm{~m}^{3} / \mathrm{s}$, or 0.6

$\left(\mathrm{m}^{3} / \mathrm{s}\right) / \mathrm{km}^{2}$ (fig. 14B). Mean daily discharge values exceeded $2.3 \mathrm{~m}^{3} / \mathrm{s}$ on 10 days in WY84 and 1 day in WY85.
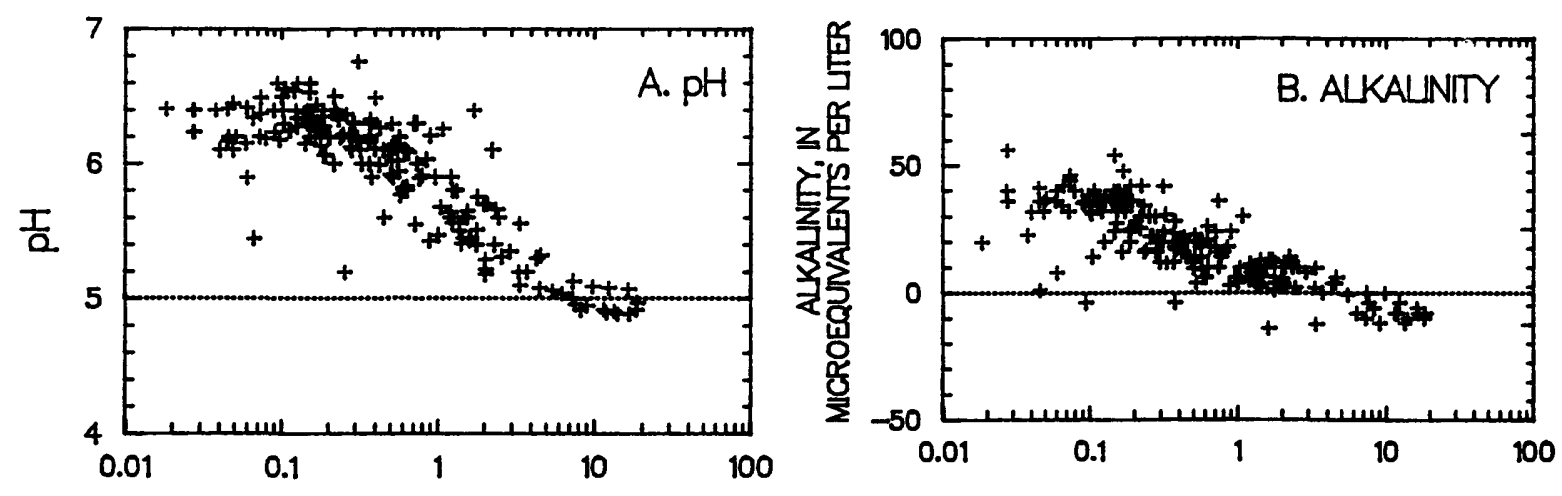

STREAM DISCHARGE, IN CUBIC METERS PER SECOND

Figure 14.--pH (left) and alkalinity (right) as a function of the log of discharge at Biscuit Brook, water years 1984-85. 
Dissolved-aluminum concentrations exceeded $200 \mu \mathrm{g} / \mathrm{L}$, the concentration considered toxic to fish (Schofield, 1981), during six of the 14 high flows studied. Toxicity levels of aluminum were determined on raw samples rather than 0.1- $\mu$ filtered samples such as those in this study, so concentrations less than $200 \mu \mathrm{g} / \mathrm{L}$ in the Biscuit Brook data may represent toxic conditions. Plots of aluminum concentration against $\mathrm{pH}$ for all the Catskill streams studied indicate that this threshold concentration was exceeded not only whenever $\mathrm{pH}$ declined below 5.0, but also at $\mathrm{pH}$ values as high as 5.6 during some storms (fig. 15). The toxicity level for aluminum, therefore, has an occurrence rate similar to that of $\mathrm{pH}$ depressions below $5.0 \mathrm{pH}$ units and may intermittently parallel $\mathrm{pH}$ depressions below $\mathrm{pH} 5.5$.

Figure 15.

Aluminum concentration as a function of $\mathrm{pH}$ at Biscuit Brook, water years 1984-85.

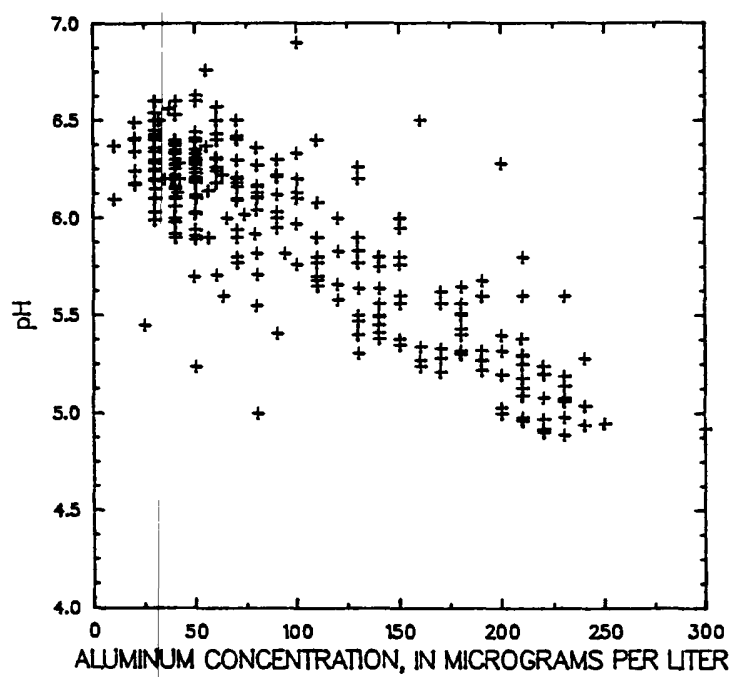

Comparison of flow duration at Biscuit Brook with the long-term flow record of the lower Neversink River (fig. 4), together with the assumption that the observed relation between stream chemistry and discharge during this study was typical of the long-term pattern, indicates that stream pH will go below 5.0 and the concurrent aluminum concentrations will reach $200 \mu \mathrm{g} / \mathrm{L}$ or higher on 4 days per year. This value should be interpreted with caution, however, because projection of the recurrence probabilities from large watersheds to headwater basins is uncertain (T. J. Zembrzuski, U.S. Geological Survey, oral commun., 1986).

The data presented herein indicate that stream-water alkalinity generated from weathering reactions in the Biscuit Brook watershed is decreased by sulfuric and nitric acid of atmospheric origin, and possibly by organic acids from biological activity in the watershed soils. The sensitivity of surface water to acidification has been shown to depend on the rate at which base cations are released relative to the rate of acid-anion deposition. To achieve electroneutrality, a deficit in base cations is balanced by an increase in protolytic cations--hydrogen and free aluminum (Driscoll and Newton, 1985). Increases in protolytic-cation concentrations in Adirondack lake outlets seemed to begin when the concentration of acidic anions $\left(\mathrm{SO}_{4}+\right.$ $\mathrm{NO}_{3}$ ), expressed in $\mu \mathrm{eq} / \mathrm{L}$, approached the concentration of the total base cations $(\mathrm{Ca}+\mathrm{Mg}+\mathrm{Na}+\mathrm{K}$ ) (Driscoll and Newton, 1985). A similar trend is evident at Biscuit Brook, where hydrogen and aluminum concentrations begin to 
increase when the concentration of acidic anions exceed 90 percent of the base-cation concentrations (fig. 16). Increases in sulfuric and nitric acid loading to Biscuit Brook are therefore accompanied by releases of aluminum and hydrogen to the stream water.

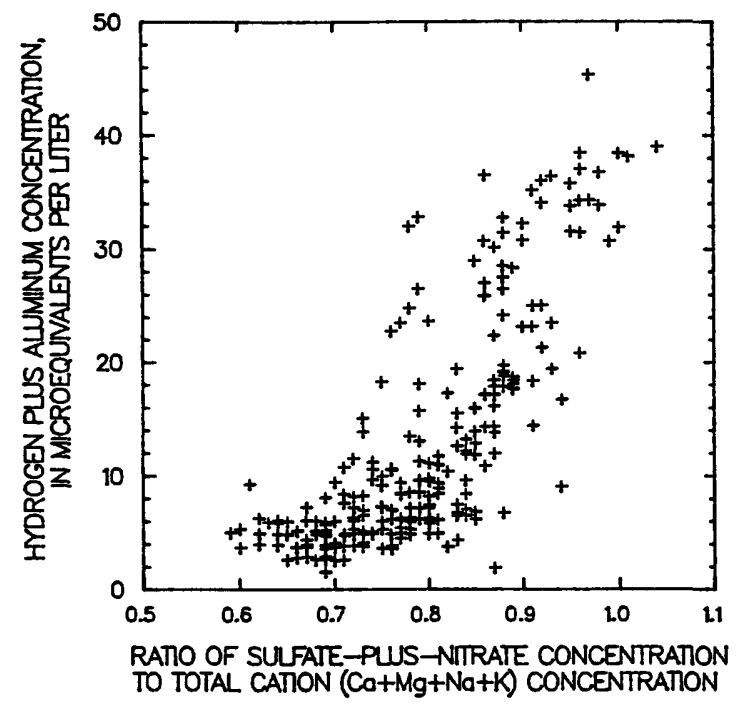

Figure 16.

Acidic cation concentrations as a function of the ratio of anion to base-cation concentrations in Biscuit Brook, water years $1984-85$.

\section{SUMMARY AND CONCLUSIONS}

Data from water-sample collection during 2 water years and 14 stormflows at Biscuit Brook in the Neversink River basin indicate that stream-water quality and precipitation chemistry are representative of other watersheds within the Catskill region and are comparable to those in watersheds in other parts of the Northeast that are receiving acidic precipitation. Water-balance calculations indicate that water years 1984 and 1985 (WY84, WY85) had distinctly different hydrologic conditions--WY84 was wetter than normal and ended with a drought, whereas WY 85 was dryer than normal and ended with Hurricane Gloria on September 27-28. Annual precipitation during WY84 was $167.9 \mathrm{~cm}$, of which 66 percent became runoff and 34 percent was lost as evapotranspiration. Annual precipitation during wY85 was $129.7 \mathrm{~cm}$, of which 56 percent became runoff and 44 percent was lost as evapotranspiration. Precipitation caused significantly higher peak flows and more frequent high flows in WY84 than in WY85, but base-flow hydrographs for the 2 years were similar. The slope of the flow-duration curve for both years indicates a generally short residence time for precipitation in the Biscuit Brook basin.

Precipitation chemistry at Biscuit Brook during the study was comparable to that observed at other deposition-monitoring stations in the Northeast. Hydrogen and sulfate were the dominant species, and $\mathrm{pH}$ averaged 4.25 .

Concentrations of sulfate and nitrate declined in winter and increased during spring and summer. Chemical concentrations during WY84 were comparable to those during WY85. Differences in chemical-deposition rates for the 2 years were the result of the greater precipitation volume during WY84 than in WY85. Chemical loading from wet precipitation had a normal seasonal distribution during WY 84 but increased toward the end of WY 85 . 
Concentrations of chloride, nitrate, and sulfate in Biscuit Brook were comparable to those observed at other Catskill streams being monitored, as well as those in several Adirondack lake outlets and Hubbard Brook, N.H. This similarity indicates atmospheric deposition to be the primary source of sulfate and nitrate in streams. Bicarbonate formed from 3 to 15 percent of the total anion concentration in these streams.

The correlation between stream chemistry and stream discharge was significant (99 percent probability level) for most major constituents. Concentrations of most constituents decreased with increased discharge as a result of dilution, although seasonal conditions, such as leaf-fall and biological activity, caused some departures. For example, potassium and nitrate concentrations were substantially affected by biological activity, and all concentrations increased during small stormflows in the fall, when decomposition of freshly fallen leaves in the watershed caused the release of major constituents.

A cumulative chemical budget was developed in which the weekly balance of chemical inputs and outputs was computed from weekly precipitation data and daily stream concentrations calculated from the relation of discharge to concentration. Results indicate a net loss of all major constituents from the Biscuit Brook watershed during $W Y 84$ and of all constituents except nitrate during wY85. Contributions from dry deposition were not accounted for in the cumulative budget calculations and might form a significant percentage of the total input to Biscuit Brook, which could explain some of the apparent losses indicated by the input/output balance. Stream yields of nitrate that were obtained from the discharge relations were overestimated, primarily because of biological uptake of nitrogen within the watershed during the summer. The combined input load of nitrate and ammonium were similar to the stream's nitrate yield in WY84. Weathering of sulfate-bearing minerals in the watershed is a possible source of sulfate, but the similarity of sulfate concentrations among streams throughout the Catskills, and the similarity of deposition-to-yield ratios to those in other mountainous areas in the Northeast and Europe in which excess sulfate in streams has been attributed to dry deposition, strongly indicates atmospheric deposition to be the primary sulfate source. The large apparent net loss of base cations may be partly the result of contributions from dry deposition also.

Changes in stream chemistry during individual storms generally were consistent with those predicted by the ratio of discharge to concentration. Changes in stream discharge during storms were far greater than changes in chemical concentrations, and ionic ratios in stream water differed from those in precipitation, which indicates substantial reaction between precipitation and surficial materials in the watershed. The chemical concentration curves of most storms were not smooth; rather, they showed pulses of increased concentration, which indicates either analytical variability or zones of differing constituent concentrations within the watershed. Nitrate concentration increased with flow throughout the year except midsummer, when biological activity took up enough nitrate in the watershed to allow dilution with increased flow. Only partial nitrate retention at Biscuit Brook was consistent with findings in other mountainous regions of the Northeast and indicates that nitric acid from precipitation is an acidifying factor in the stream water. 
Hydrogen and aluminum were released from the watershed to Biscuit Brook when acidic anion concentrations exceeded 70 percent of base-cation concentrations. Aluminum and hydrogen-ion concentrations increased with discharge, even during small stormflows. Stream pH generally fell below 5.0 at flows exceeding $7.1 \mathrm{~m}^{3} / \mathrm{s}$, and stream alkalinity was zero or less at flows exceeding $2.3 \mathrm{~m}^{3} / \mathrm{s}$. Daily flows exceeded $2.3 \mathrm{~m}^{3} / \mathrm{s}$ on 10 days in $W Y 84$ and 1 day in WY85. Aluminum concentrations exceeded $200 \mu \mathrm{g} / \mathrm{L}$, the level considered toxic to fish, during six of the 14 high flows studied. Concentrations of aluminum exceeding $200 \mu \mathrm{g} / \mathrm{L}$ occurred at $\mathrm{pH}$ values as high as 5.5 and can generally be expected whenever $\mathrm{pH}$ declines below 5.0. Stream pH declined below 5.0 during four stormflows of the 3-year study. Comparison of flow records from the study with long-term flow records from the Neversink basin indicate that, on the average, flows that depress $\mathrm{pH}$ below 5.0 will occur on 4 days per year, but this is only a rough estimate because projection of flowduration predictions from larger to smaller watersheds has uncertain accuracy.

\section{REFERENCES CITED}

Driscoll, C. T., and Newton, R. M., 1985, Chemical characteristics of Adirondack Lakes: Environmental Science and Technology, v. 19, no. 11, p. 1018-1024.

Eaton, J. S., Likens, G. E., and Bormann, F. H., 1980, wet and dry deposition of sulfur at Hubbard Brook, in Hutchinson, T. C. and Havas, M., eds., Effects of acid precipitation on terrestrial ecosystems: NATO Conference on Effects on Acid Precipitation on Vegetation and Soils, Toronto, Canada, 1978: New York, Plenum Press, p. 69-75.

Ethridge, F. G., 1977, Petrology, transport, and environment in isochronous Upper Devonian sandstone and siltstone units, New York: Journal of Sedimentary Petrology, v. 47, no. 1, p. 53-65.

Feller, M. C., and Kimmins, J. P., 1979, Chemical characteristics of small streams near Haney in southwestern British Columbia: Water Resources Research, v. 15, no. 2, p. 247-258.

Firda, G. D., Lumia, R., Archer, R. J., and Burke, P. M., 1984, water resources data New York, water year 1984--volume 1, Eastern New York excluding Long Island: U.S. Geological Survey water-Data Report NY-84-1, 249 p.

1985, Water resources data, New York, water year 1985--volume 1, Eastern New York excluding Long Island: U.S. Geological Survey Water-Data Report NY-85-1, $268 \mathrm{p}$.

Fishman, M. J., and Friedman, L. C., 1985, Methods for determination of inorganic substances in water and fluvial sediments: U.S. Geological Survey Techniques of Water Resources Investigations, Book 5, Chapter A1, 709 p.

Galloway, J. N., Schofield, C. L., Hendrey, G. R., Peters, N. E., and Johannes, A. J., 1986, Processes and causes of lake acidification during spring snowmelt in the west-central Adirondack Mountains, New York. Canadian Journal of Fisheries and Aquatic Sciences, 21 p. 


\section{REFERENCES CITED (continued)}

Galloway, J. N., Schofield, C. L., Peters, N. E., Hendrey, G. R., and Altwicker, E. R., 1983, Effects of atmospheric sulfur on the composition of three Adirondack lakes: Canadian Journal of Fisheries and Aquatic Sciences, v. 40, no. 6, p. 799-806.

Galloway, J. N. and Whelpdale, D. M., 1980, An atmospheric sulfur budget for eastern North America: Atmospheric Environment, v. 14, p. 409-417.

Glass, G. E. and Loucks, O. L., 1986, Implications of a gradient in acid and ion deposition across the northern Great Lakes States: Environmental Science and Technology, v. 20, no. 1, p. 35-43.

Hamon, R. W., 1961, Estimating potential evapotranspiration: Journal of the Hydraulics Division, American Society of Civil Engineers, v. 87, no. HY3, p. 107-120.

Hem, John D., 1970, Study and interpretation of the chemical characteristics of natural water: U.S. Geological Survey Water Supply Paper 1473, 363 p.

Hemond, H. F., and Eshleman, K. N., 1984, Neutralization of acid deposition by nitrate retention at Bickford watershed, Massachusetts: Water Resources Research, v. 20, no. 11, p. 1718-1724.

Hendry, M. J., Cherry, J. A., and Wallick, E. I., 1986, Origin and distribution of sulfate in a fractured till in southern Alberta, Canada: Water Resources Research, v. 22, no. 1, p. 45-61.

Henriksen, Arne, 1979, A simple approach for identifying and measuring acidification of freshwater: Nature, v. 278, p. 542-545.

Johnson, N. M., Likens, G. E., Bormann, F. H., Fisher, D. W., and Pierce, R. S., 1969, A working model for the variation in streamwater chemistry at the Hubbard Brook Experimental Forest, New Hampshire: Water Resources Research, v. 5, no. 6, p. 1353-1363.

Junge, C. E., and Werby, R. T., 1958, The concentration of chloride, sodium, potassium, calcium, and sulfate in rainwater over the United States: Journal of Meteorology, v. 15, no. 5, p. 417-425.

Kennedy, V. C., Kendall, C., Zellweger, G. W., Wyerman, T. A., Avanzino, R. J., 1986, Determination of the components of stormflow using water chemistry and environmental isotopes, Mattole River basin, California: Journal of Hydrology, v. 84, p. 107-140.

Kennedy, V. C., Zelleweger, G. W., and Jones, B. F., 1974, Filter pore-size effect on the analysis of $\mathrm{Al}, \mathrm{Fe}, \mathrm{Mn}$, and $\mathrm{Ti}$ in water: Water Resources Research, v. 10, p. 785-790.

Knox, C. E., and Nordenson, T. J., 1955, Average annual runoff and precipitation in the New England-New York area: U.S. Geological Survey Hydrologic Investigations Atlas, $\mathrm{HA}-7,6$ sheets, scale 1:1,000,000. 


\section{REFERENCES CITED (contInued)}

Kudish, M., 1985, Forest history of Frost Valley: Adirondack Magazine, April 1985 , p. $16-18$.

Likens, G. E., Bormann, F. H., Pierce, R. S., Eaton, J. S., and Johnson, N. M., 1977, Biogeochemistry of a forested ecosystem: New York, SpringerVerlag, $146 \mathrm{p}$.

Lynch, D. D., and Dise, N. B., 1985, Sensitivity of stream basins in Shenandoah National Park to acid deposition: U.S. Geological Survey Water Resources Investigations Report 85-115, 61 p.

Lynch, J. A., Hanna, M. C., and Corbett, E. S., 1984, Predicting pH, alkalinity, and total acidity in streamwater during episodic events: Water Resources Research, v. 22, no. 6, p. 905-12.

Lynch, J. A., Corbett, E. S., and Rishel, G. B., 1985, Atmospheric deposition --spatial and temporal variation in Pennsylvania, 1984: University Park, Pa., Pennsylvania State University, Institute for Research on Land and Water Resources, no. LW8405A, 228 p.

Murdoch, P. S., Peters, N. E., and Newton, R. M., 1987, Hydrologic analysis of two headwater lake basins of differing lake $\mathrm{pH}$ in the west-central Adirondack Mountains of New York: U.S. Geological Survey Water-Resources Investigations Report 84-4313, 49 p.

NADP Quality Assurance Steering Committee, 1984, NADP quality assurance plan --deposition monitoring: National Atmospheric Deposition Program, IR-7, $39 \mathrm{p}$.

NADP/NTN Coordinators office, 1986, NADP/NTN annual data summary, precipitation chemistry in the United States, 1984: Fort Collins, Colo. Colorado State University, Natural Resource Ecology Laboratory, 240 p.

National Atmospheric Deposition Program, 1982, NADP instruction manual--site operation: Fort Collins, Colo., Colorado State University, Natural Resource Ecology Laboratory, 23, p.

National Oceanic and Atmospheric Administration, 1950-1985, Climatologic data annual summary: Asheville, N.C., National Climatic Data Center, p. 62-94.

Parker, G. G., Hely, A. G., Keighton, W. B., Olmstead, F. H., and others, 1964, Water resources of the Delaware River basin: U.S. Geological Survey Professional Paper 381, 200 p.

Peart, D. B., and Thomas, N. A., 1984, Quality assurance report--Atlanta Central Laboratory, Denver Central Laboratory: U.S. Geological Survey Technical Memorandum no. 84.12, 79 p.

Peters, N. E., Schroeder, R. A., and Troutman, D. E., 1982, Temporal trends in the acidity of precipitation and surface waters of New York: U.S. Geological Survey Water-Supply Paper 2188, 35 p. 


\section{REFERENCES (contInued)}

Porterfield, George, 1972, Computation of fluvial-sediment discharge: U.S. Geological Survey Techniques of Water-Resources Investigations, Book 3, Chapter C3, $66 \mathrm{p}$.

Rantz, S. E., 1982, Measurement and computation of streamflow, volume 1, Measurement of stage and discharge: U.S. Geological Survey Water-supply Paper 2175, 284 p.

Rich, J. L., 1934, Glacial geology of the Catskills: New York State Museum Bulletin 299, 180 p.

Schofield, C. L., 1981, Acid precipitation--Effects on fish: Ambio, v. 5, no. 5-6, p. 228-238.

Searcy, J. K., 1963, Flow-duration curves, manual of hydrology--part 2. lowflow techniques: U.S. Geological Survey Water-Supply Paper 1542-A, 33 p.

Tornes, L. A., 1979, Soil survey of Ulster County, New York: U.S. Department of Agriculture, Soil Conservation Service, 273 p.

U.S. Department of Commerce, 1968, Climatic atlas of the United States: Washington, D.C., 80 p.

Way, J. H., 1972, A more detailed discussion of the depositional environmental analysis--middle and upper Devonian sedimentary rocks, Catskill Mountain area, New York: Troy, N.Y., Rensselaer Polytechnic Institute, Ph.D. Dissertation, $145 \mathrm{p}$.

Wershaw, R. L., Fishman, M. J., Grabbe, R. R., and Lowe, L. E., 1983, Methods for the determination of organic substances in water and fluvial sediments, U.S. Geological Survey Techniques of Water-Resources Investigations, Book 5, Laboratory Analysis, Chapter A3; 173 p.

Winter, T. C., 1981, Uncertainties in estimating the water balance of lakes: Water Resources Bulletin, v. 17, no. 1, p. 82-114.

Woodrow, D. L., 1985, Paleogeography, paleoclimate, and sedimentary processes of the Late Devonian Catskill Delta, in Woodrow, D. L., and Sevon, W. D., 201, eds., The Catskill Delta: Geological Society of America Special Paper 246 p. 


\section{APPENDIXES}

A. Concentrations of major constituents in Biscuit Brook water samples, April 1983 through September 1985

B. Concentrations of minor constituents in Biscuit Brook water samples, April 1983 through September $1985 \ldots \ldots \ldots \ldots \ldots \ldots \ldots \ldots \ldots \ldots 50$

C. Concentrations of major constituenst in weekly precipitation samples from the National Trends Network monitoring station at Biscuit Brook, water years $1984-85 \ldots \ldots \ldots \ldots \ldots \ldots \ldots \ldots \ldots \ldots \ldots \ldots . \ldots \ldots$

D. Assessment of data quality $\ldots \ldots \ldots \ldots \ldots \ldots \ldots \ldots \ldots \ldots \ldots \ldots \ldots \ldots$ 


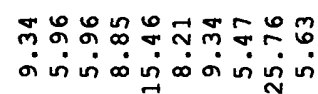

ดำ ำ

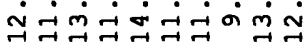

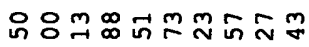

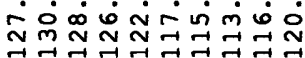

८০০৪৪০০০০০

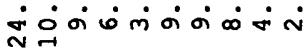

$, 1, \stackrel{0}{0}, 1, \stackrel{\infty}{0}, 1,1$

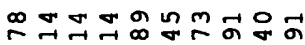

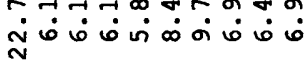

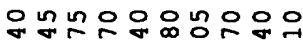

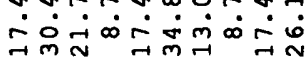

๕

ชี

01

焉范

过

愛

总

ฮั

吉

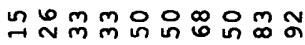

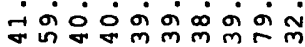

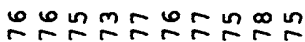
Э

0000000000 ํㅗㄴ

象 जि نे

응ㅇㅇㅇㅇㅇㅇㅇㅇㅇ응 ล ลั่ง்

조ำ

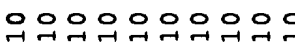

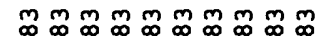

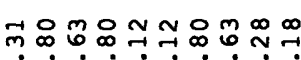

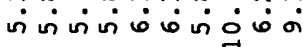

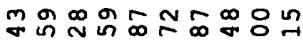

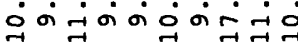

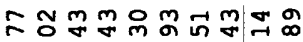

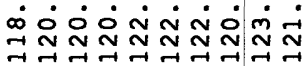

양ㅇㅇㅇㅇㅇㅇㅇㅇㅇㅇㅇㅇ نं नंब

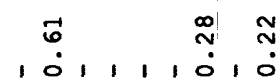

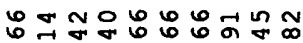

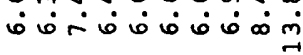

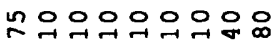

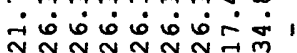

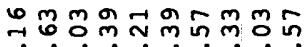

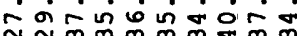

$\sim^{\infty} \infty \infty^{\infty} \infty \infty$ ธ่ㅇㅇㅇㅇㅇㅇㅇㅇㅇ

0000000000 N่

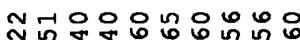
กิ

ㅇㅇㅇㅇㅇㅇㅇ응

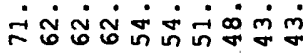

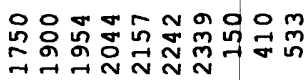

요요

엉ㅇㅁ웅ㅇㅇㅇㅇㅇㅇㅔ क

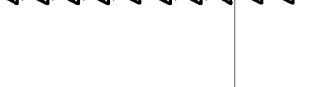

న

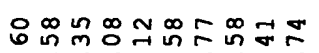

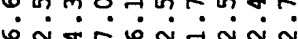

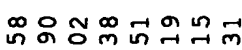

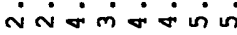

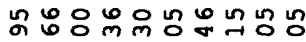

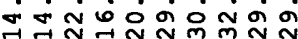

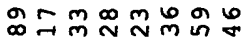

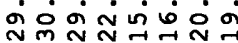

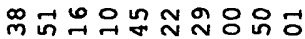

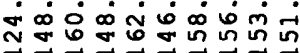

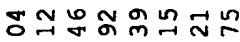

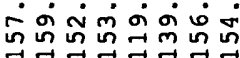

ㅇㅇ 용ㅇㅇ

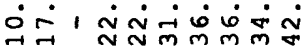

৪:८:०८:०

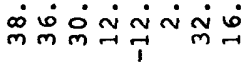

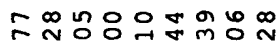

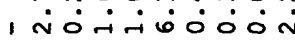

Nㅇㅇㅀㅇㅇㅇㅇํㅇㅇㅇ

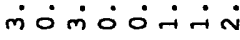

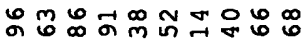

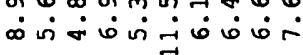

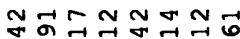

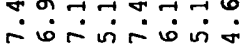

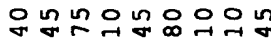
1

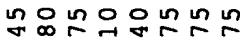

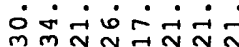

ํㅜㅇํำ ம்

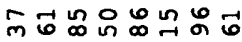

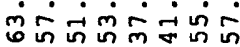

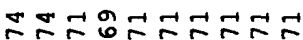

우으ํㅠํำ

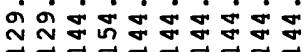

gु

0000000000 ஸे

O O NOUOOO

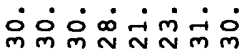

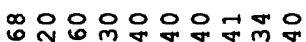

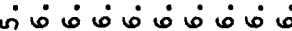

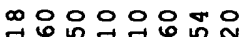
ம்

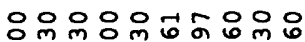

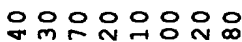
ம்

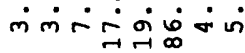

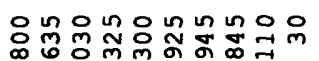

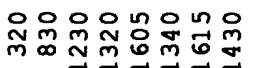

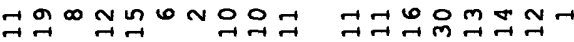

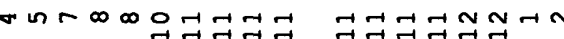

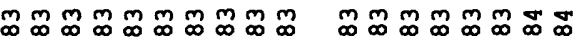




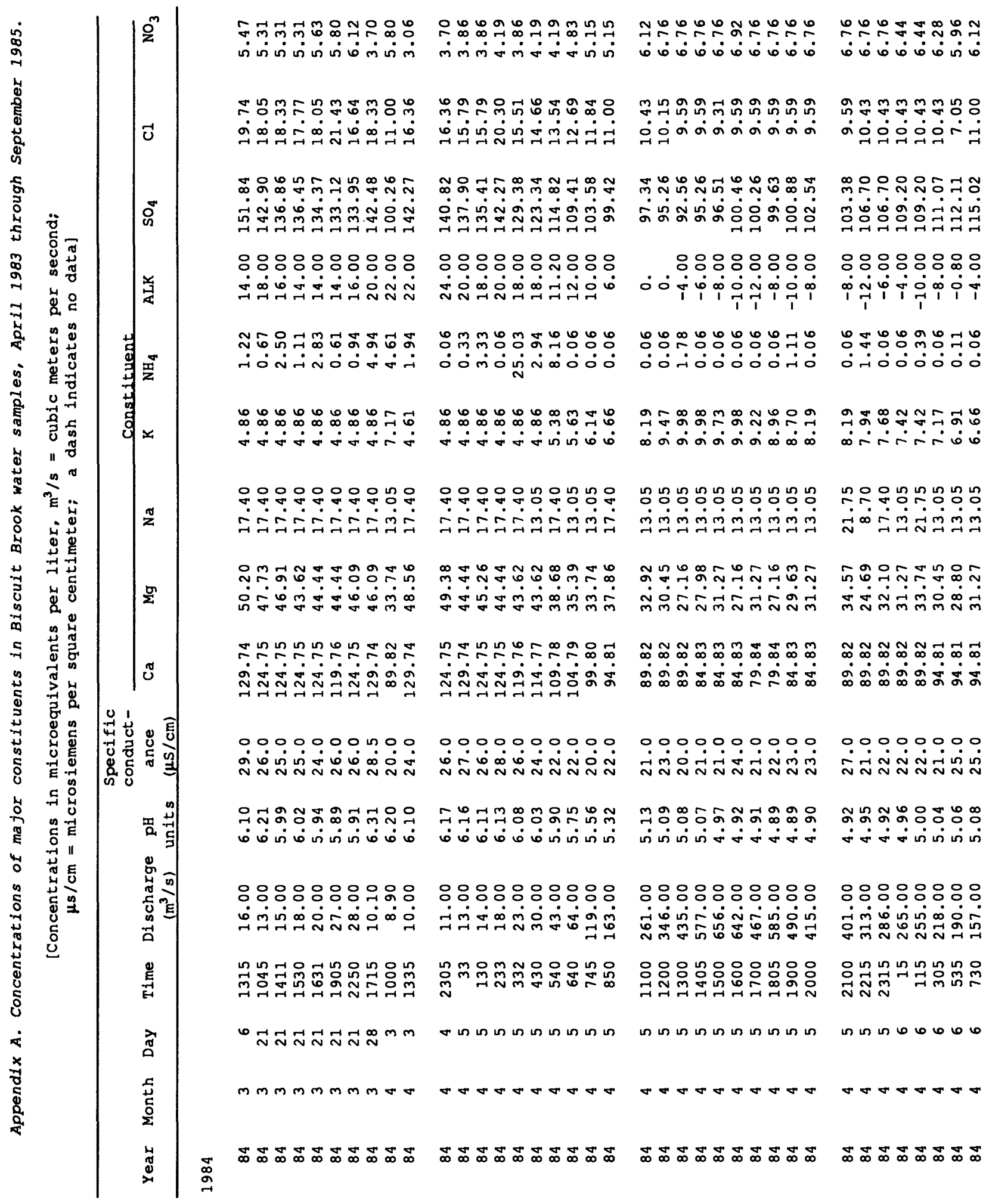




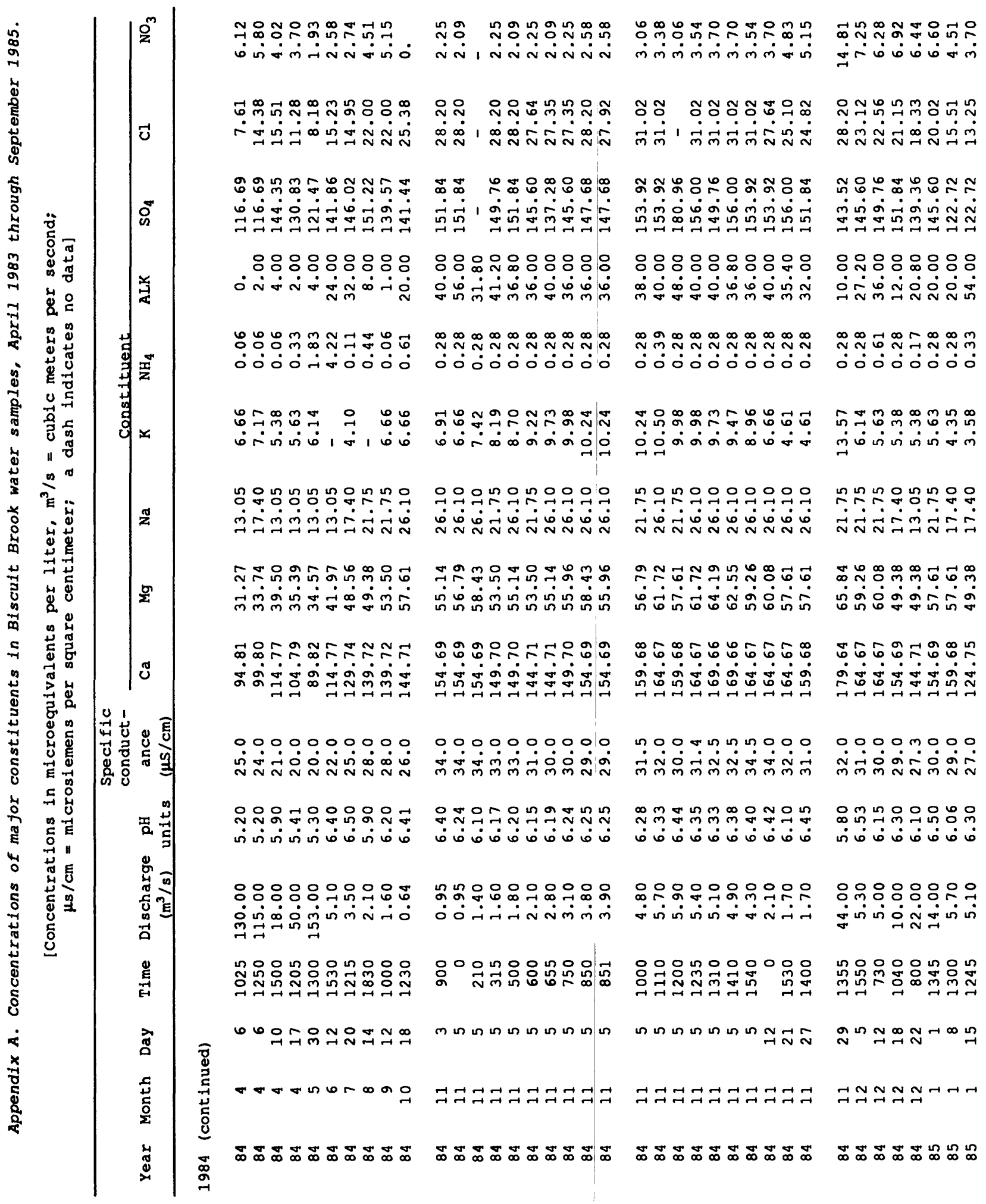




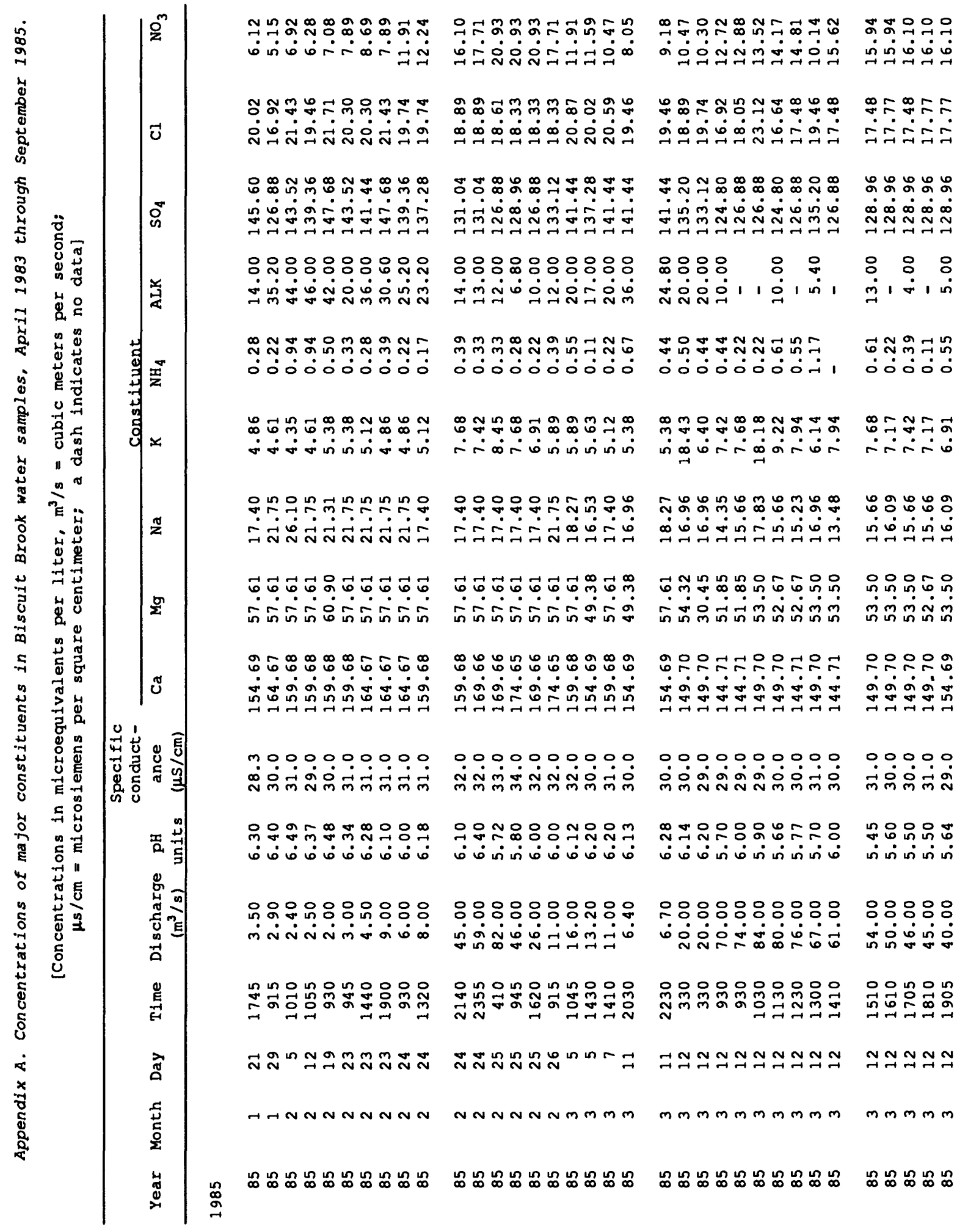




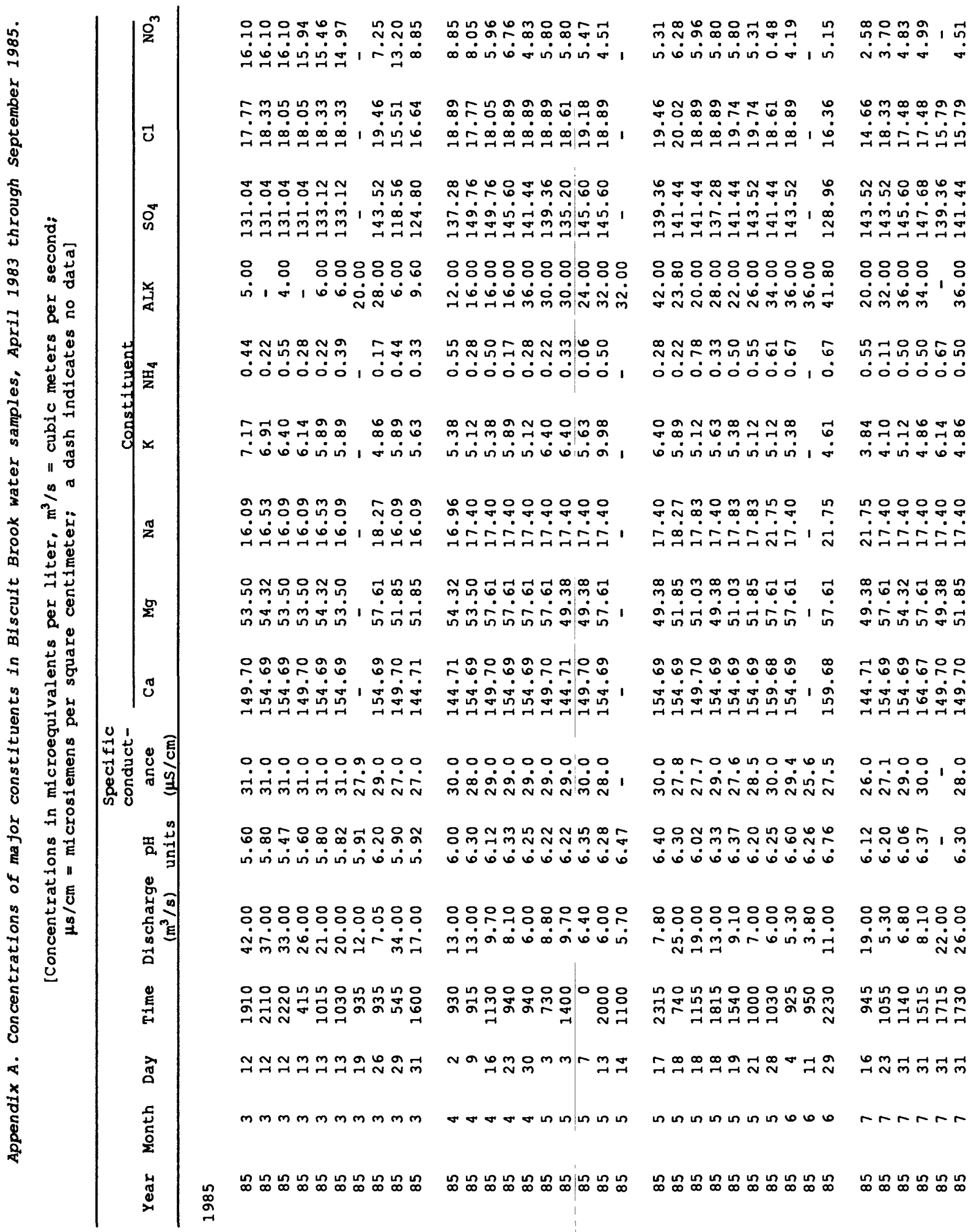




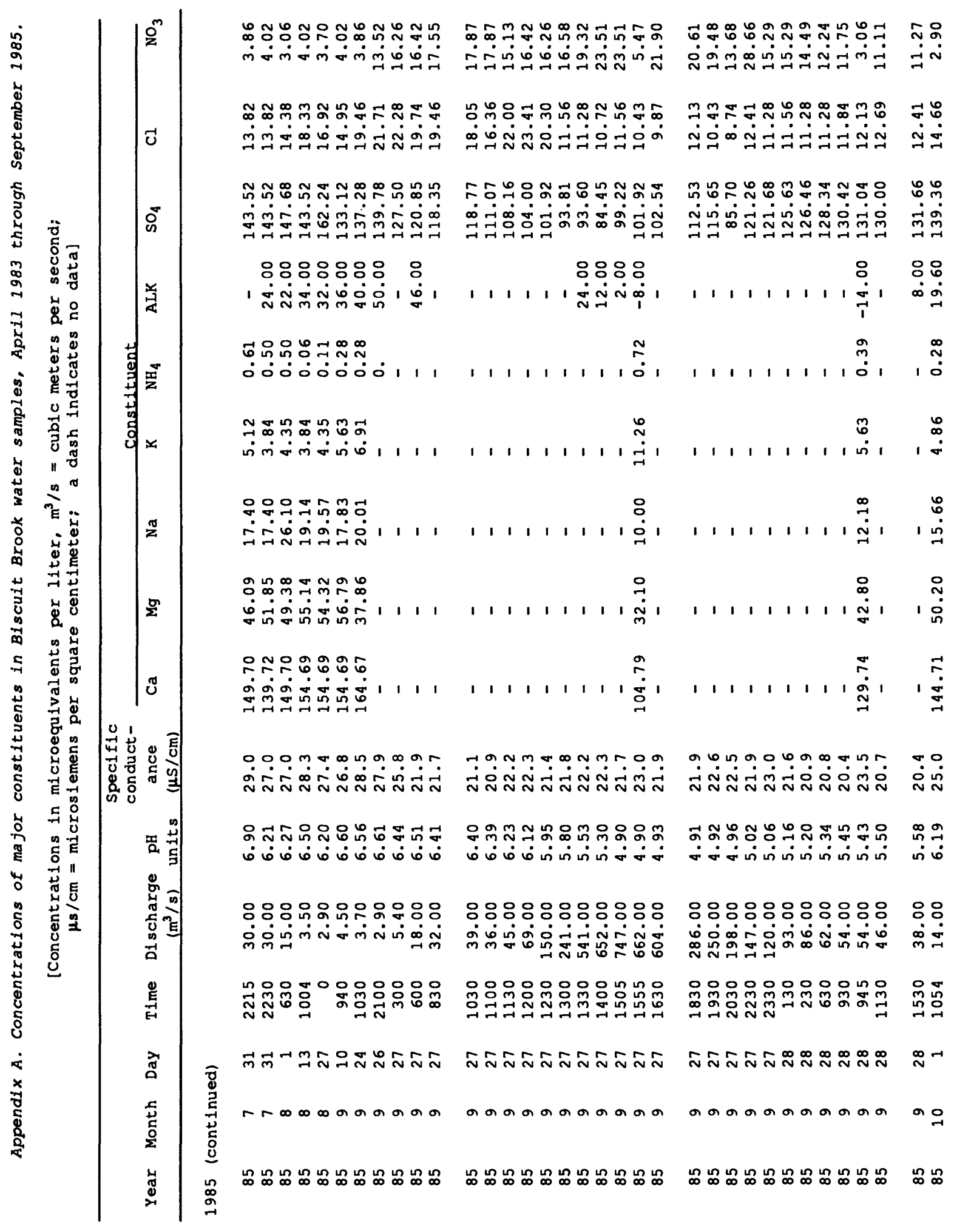


Appendix B. Concentrations of minor constituents in Biscuit Brook water samples, April 1983 through September 1985.

[Concentrations in microequivalents per liter;

DOC $=$ dissolved organic carbon, ${ }^{\circ} \mathrm{C}=$ degrees Celcius]

\begin{tabular}{|c|c|c|c|c|c|c|c|c|c|}
\hline \multirow[b]{2}{*}{$\begin{array}{l}\text { Year } \\
\mathrm{PO}_{4}\end{array}$} & \multirow[b]{2}{*}{ Month } & \multirow[b]{2}{*}{ Day } & \multirow[b]{2}{*}{ Time } & \multirow[b]{2}{*}{$\begin{array}{l}\text { Temp } \\
\left({ }^{\circ} \mathrm{C}\right)\end{array}$} & \multicolumn{5}{|c|}{ Constituents } \\
\hline & & & & & Al & $\mathbf{F e}$ & $\mathrm{Mn}$ & Si & DOC \\
\hline
\end{tabular}

1983

\begin{tabular}{|c|c|c|c|c|c|c|c|c|c|c|}
\hline 83 & 4 & 10 & 24 & 5.5 & 210 & 53.0 & 18.0 & 1.4 & 3.6 & 0.00 \\
\hline 83 & 4 & 10 & 521 & 5.0 & 120 & 5.0 & 14.0 & 1.6 & 2.3 & 0.00 \\
\hline 83 & 4 & 10 & 932 & 4.5 & 70 & 6.0 & 15.0 & 1.6 & 2.2 & 0.00 \\
\hline 83 & 4 & 10 & 1048 & 4.5 & 80 & 7.0 & 15.0 & 1.6 & 2.4 & 0.00 \\
\hline 83 & 4 & 10 & 1145 & 4.8 & 80 & 7.0 & 15.0 & 1.5 & 2.7 & 0.00 \\
\hline 83 & 4 & 10 & 1245 & 4.8 & 140 & 22.0 & 17.0 & 1.3 & 2.7 & 0.00 \\
\hline 83 & 4 & 10 & 1348 & 5.0 & 130 & 21.0 & 27.0 & 1.5 & 5.9 & 0.00 \\
\hline 83 & 4 & 10 & 1446 & 5.0 & 150 & 19.0 & 36.0 & 2.1 & 4.0 & 0.00 \\
\hline 83 & 4 & 10 & 1546 & 4.8 & 210 & 17.0 & 33.0 & 1.3 & 7.1 & 0.00 \\
\hline 83 & 4 & 10 & 1643 & 4.8 & 210 & 16.0 & 35.0 & 1.4 & 3.5 & 0.00 \\
\hline 83 & 4 & 10 & 1750 & 4.8 & 190 & 14.0 & 35.0 & 1.4 & 4.4 & 0.00 \\
\hline 83 & 4 & 10 & 1900 & 4.5 & 180 & 13.0 & 35.0 & 1.4 & 3.0 & 0.00 \\
\hline 83 & 4 & 10 & 1954 & 4.5 & 200 & 15.0 & 35.0 & 1.4 & 3.0 & 0.00 \\
\hline 83 & 4 & 10 & 2044 & 4.5 & 180 & 15.0 & 33.0 & 1.4 & 3.1 & 0.00 \\
\hline 83 & 4 & 10 & 2157 & 4.5 & 230 & 15.0 & 34.0 & 1.5 & 3.4 & 0.00 \\
\hline 83 & 4 & 10 & 2242 & 4.5 & 180 & 16.0 & 33.0 & 1.4 & 3.1 & 0.00 \\
\hline 83 & 4 & 10 & 2339 & 5.0 & 190 & 16.0 & 33.0 & 1.5 & 3.1 & 0.00 \\
\hline 83 & 4 & 11 & 150 & 5.0 & 180 & 15.0 & 31.0 & 1.5 & 3.2 & 0.00 \\
\hline 83 & 4 & 11 & 410 & 5.0 & 170 & 16.0 & 29.0 & 1.4 & 4.1 & 0.00 \\
\hline 83 & 4 & 11 & 533 & 5.0 & 210 & 27.0 & 27.0 & 1.4 & 3.1 & 0.00 \\
\hline 83 & 4 & 11 & 800 & 5.0 & 190 & 16.0 & 27.0 & 1.5 & 4.3 & 0.00 \\
\hline 83 & 5 & 19 & 1635 & 8.5 & 100 & 7.0 & 3.0 & 1.5 & 1.8 & 0.00 \\
\hline 83 & 7 & 8 & 1030 & 14.0 & 30 & 6.0 & 1.0 & 2.2 & 2.0 & - \\
\hline 83 & 8 & 12 & 1325 & 4.0 & 90 & 14.0 & 7.0 & 2.2 & 3.8 & 0.00 \\
\hline 83 & 8 & 15 & 1300 & 14.0 & 60 & 3.0 & 1.0 & 2.4 & 1.4 & 0.00 \\
\hline 83 & 10 & 6 & 925 & - & 20 & 4.0 & 6.0 & 2.6 & 2.0 & 0.00 \\
\hline 83 & 11 & 2 & 945 & 5.0 & 20 & 6.0 & 1.0 & 2.2 & 2.3 & 0.01 \\
\hline 83 & 11 & 10 & 1845 & 6.0 & 20 & 3.0 & 3.0 & 2.1 & 2.0 & 0.01 \\
\hline 83 & 11 & 10 & 2110 & 5.5 & 20 & 4.0 & 3.0 & 2.0 & 3.1 & 0.01 \\
\hline 83 & 11 & 11 & 30 & 6.0 & 40 & 4.0 & 3.0 & 2.0 & 3.3 & 0.01 \\
\hline 83 & 11 & 11 & 320 & 6.0 & 20 & 4.0 & 2.0 & 2.1 & 3.1 & 0.01 \\
\hline 83 & 11 & 11 & 830 & 6.0 & 30 & 3.0 & 2.0 & 2.1 & 2.7 & 0.01 \\
\hline 83 & 11 & 16 & 1230 & 5.0 & 70 & 11.0 & 7.0 & 2.3 & 3.1 & 0.02 \\
\hline 83 & 11 & 30 & 1320 & 3.5 & 80 & 10.0 & 11.0 & 2.0 & 2.7 & 0.00 \\
\hline 83 & 12 & 13 & 1605 & - & 230 & 19.0 & 69.0 & 1.4 & 5.0 & 0.01 \\
\hline 83 & 12 & 14 & 1340 & 5.0 & 210 & 13.0 & 55.0 & 1.5 & 4.2 & 0.01 \\
\hline
\end{tabular}

1984

$\begin{array}{lrrrrrrrrrr}84 & 1 & 12 & 1615 & 0 . & 30 & 3.0 & 2.0 & 2.3 & 2.6 & 0.00 \\ 84 & 2 & 1 & 1430 & 0 . & 50 & 5.0 & 1.0 & 2.0 & 2.6 & 0.00 \\ 84 & 3 & 6 & 1315 & 0.5 & 10 & 4.0 & 6.0 & 1.8 & 1.5 & 0.00 \\ 84 & 3 & 21 & 1045 & 2.0 & 50 & 4.0 & 10.0 & 1.6 & 1.9 & 0.00 \\ 84 & 3 & 21 & 1411 & 2.0 & 30 & 3.0 & 10.0 & 1.6 & 2.0 & 0.00 \\ 84 & 3 & 21 & 1530 & 1.5 & 50 & 4.0 & 11.0 & 1.6 & 2.2 & 0.00 \\ 84 & 3 & 21 & 1631 & 1.5 & 50 & 5.0 & 13.0 & 1.5 & 1.8 & 0.01 \\ 84 & 3 & 21 & 1905 & 1.0 & 50 & 6.0 & 16.0 & 1.5 & 1.9 & 0.00 \\ 84 & 3 & 21 & 2250 & 1.0 & 50 & 7.0 & 19.0 & 1.5 & 2.8 & 0.00 \\ 84 & 3 & 28 & 1715 & 1.5 & 50 & 5.0 & 5.0 & 1.6 & 1.8 & 0.02 \\ 84 & 4 & 3 & 1000 & 1.5 & 200 & 24.0 & 51.0 & 1.1 & 3.7 & 0.01\end{array}$


Appendix B. Concentrations of minor constituents in Biscuit Brook water samples, April 1983 through September 1985 (continued).

[Concentrations in microequivalents per liter

$\mathrm{DOC}=$ dissolved organic carbon, ${ }^{\circ} \mathrm{C}=$ degrees Celcius]

\begin{tabular}{|c|c|c|c|c|c|c|c|c|c|}
\hline \multirow[b]{2}{*}{$\begin{array}{l}\text { Year } \\
\mathrm{PO}_{4}\end{array}$} & \multirow[b]{2}{*}{ Month } & \multirow{2}{*}{\multicolumn{2}{|c|}{ Day Time }} & \multirow[b]{2}{*}{$\begin{array}{l}\text { Temp } \\
\left({ }^{\circ} \mathrm{C}\right)\end{array}$} & \multicolumn{5}{|c|}{ constituents } \\
\hline & & & & & $\mathrm{A} 1$ & Fe & $M n$ & si & DOC \\
\hline
\end{tabular}

1984 (continued)

\begin{tabular}{|c|c|c|c|c|c|c|c|c|c|c|}
\hline 84 & 4 & 3 & 1335 & 4.5 & 50 & 3.0 & 6.0 & 1.6 & 1.7 & 0.01 \\
\hline 84 & 4 & 4 & 2305 & 2.0 & 80 & 3.0 & 8.0 & 1.6 & 1.5 & 0.00 \\
\hline 84 & 4 & 5 & 33 & 2.5 & 80 & 3.0 & 8.0 & 1.5 & 1.6 & 0.02 \\
\hline 84 & 4 & 5 & 130 & 2.5 & 80 & 5.0 & 8.0 & 1.5 & 1.6 & 0.01 \\
\hline 84 & 4 & 5 & 233 & 2.0 & 80 & 6.0 & 10.0 & 1.5 & 1.6 & 0.00 \\
\hline 84 & 4 & 5 & 332 & 2.0 & 110 & 8.0 & 11.0 & 1.4 & 1.8 & 0.02 \\
\hline 84 & 4 & 5 & 430 & 2.0 & 90 & 10.0 & 15.0 & 1.4 & 2.1 & 0.00 \\
\hline 84 & 4 & 5 & 540 & 1.5 & 110 & 11.0 & 19.0 & 1.3 & 2.7 & 0.01 \\
\hline 84 & 4 & 5 & 640 & 1.0 & 140 & 14.0 & 25.0 & 1.2 & 2.8 & 0.02 \\
\hline 84 & 4 & 5 & 745 & 1.5 & 150 & 18.0 & 35.0 & 1.2 & 3.2 & 0.03 \\
\hline 84 & 4 & 5 & 850 & 1.5 & 180 & 22.0 & 45.0 & 1.1 & 3.4 & 0.00 \\
\hline 84 & 4 & 5 & 1100 & 1.5 & 210 & 25.0 & 58.0 & 1.0 & 4.2 & 0.00 \\
\hline 84 & 4 & 5 & 1200 & 1.5 & 210 & 28.0 & 65.0 & 1.0 & 4.4 & 0.00 \\
\hline 84 & 4 & 5 & 1300 & 1.3 & 220 & 29.0 & 71.0 & 0.9 & 4.4 & 0.00 \\
\hline 84 & 4 & 5 & 1405 & 1.5 & 230 & 27.0 & 77.0 & 0.9 & 4.4 & 0.00 \\
\hline 84 & 4 & 5 & 1500 & 1.5 & 220 & 30.0 & 78.0 & 0.9 & 4.2 & 0.01 \\
\hline 84 & 4 & 5 & 1600 & 1.5 & 300 & 110.0 & 100.0 & 1.1 & 4.1 & 0.01 \\
\hline 84 & 4 & 5 & 1700 & 2.0 & 220 & 31.0 & 77.0 & 0.9 & 4.2 & 0.37 \\
\hline 84 & 4 & 5 & 1805 & 1.7 & 230 & 30.0 & 77.0 & 0.9 & 4.0 & 0.15 \\
\hline 84 & 4 & 5 & 1900 & 1.9 & 230 & 30.0 & 76.0 & 1.0 & 3.9 & 0.21 \\
\hline 84 & 4 & 5 & 2000 & 1.7 & 220 & 28.0 & 73.0 & 1.0 & 3.7 & 0.27 \\
\hline 84 & 4 & 5 & 2100 & 1.7 & 220 & 30.0 & 71.0 & 1.0 & 3.6 & 0.00 \\
\hline 84 & 4 & 5 & 2215 & 2.2 & 250 & 25.0 & 69.0 & 1.0 & 3.5 & 0.01 \\
\hline 84 & 4 & 5 & 2315 & 2.0 & 220 & 23.0 & 66.0 & 1.0 & 3.6 & 0.01 \\
\hline 84 & 4 & 6 & 15 & 2.0 & 210 & 22.0 & 65.0 & 1.0 & 3.5 & 0.01 \\
\hline 84 & 4 & 6 & 115 & 2.0 & 200 & 23.0 & 63.0 & 1.1 & 3.0 & 0.00 \\
\hline 84 & 4 & 6 & 305 & 2.0 & 240 & 22.0 & 60.0 & 1.1 & 3.2 & 0.00 \\
\hline 84 & 4 & 6 & 535 & 2.0 & 230 & 20.0 & 56.0 & 1.1 & 3.0 & 0.01 \\
\hline 84 & 4 & 6 & 730 & 2.0 & 230 & 18.0 & 54.0 & 1.2 & 3.0 & 0.00 \\
\hline 84 & 4 & 6 & 1025 & 2.3 & 220 & 15.0 & 50.0 & 1.2 & 2.8 & 0.00 \\
\hline 84 & 4 & 6 & 1250 & 2.5 & 220 & 14.0 & 49.0 & 1.2 & 3.3 & 0.00 \\
\hline 84 & 4 & 10 & 1500 & 3.5 & 70 & 3.0 & 12.0 & 1.6 & 1.9 & 0.00 \\
\hline 84 & 4 & 17 & 1205 & 5.5 & 140 & 9.0 & 35.0 & 1.4 & 2.7 & 0.00 \\
\hline 84 & 5 & 30 & 1300 & 8.5 & 180 & 19.0 & 35.0 & 1.4 & 3.9 & 0.00 \\
\hline 84 & 6 & 12 & 1530 & - & - & 3.0 & 1.0 & 2.0 & 2.3 & 0.00 \\
\hline 84 & 7 & 20 & 1215 & 14.0 & 160 & 3.0 & 1.0 & 2.2 & 1.2 & 0.00 \\
\hline 84 & 8 & 14 & 1830 & 17.0 & 40 & 3.0 & 1.0 & 2.3 & 1.3 & 0.00 \\
\hline 84 & 9 & 12 & 1000 & 12.5 & 130 & 4.0 & 2.0 & 2.3 & 1.2 & 0.00 \\
\hline 84 & 10 & 18 & 1230 & 10.5 & 30 & 7.0 & 2.0 & 2.3 & 1.4 & 0.00 \\
\hline 84 & 11 & 3 & 900 & 4.5 & 30 & 3.0 & 2.0 & 1.8 & 3.0 & 0.00 \\
\hline 84 & 11 & 5 & 0 & 7.0 & 20 & 4.0 & 2.0 & 2.0 & 1.4 & 0.00 \\
\hline 84 & 11 & 5 & 210 & 7.0 & 30 & 7.0 & 2.0 & 1.8 & 1.6 & 0.00 \\
\hline 84 & 11 & 5 & 315 & 7.5 & 20 & 4.0 & 4.0 & 1.7 & 1.9 & 0.00 \\
\hline 84 & 11 & 5 & 500 & 7.5 & 30 & 7.0 & 2.0 & 1.7 & 1.9 & 0.00 \\
\hline 84 & 11 & 5 & 600 & 7.5 & 40 & 6.0 & 4.0 & 1.7 & 2.7 & 0.00 \\
\hline 84 & 11 & 5 & 655 & 8.0 & 30 & 7.0 & 6.0 & 1.7 & 14.0 & 0.00 \\
\hline 84 & 11 & 5 & 750 & 8.0 & 30 & 8.0 & 3.0 & 1.8 & 2.6 & 0.00 \\
\hline 84 & 11 & 5 & 850 & 8.0 & 50 & 9.0 & 7.0 & 1.9 & 3.2 & 0.00 \\
\hline
\end{tabular}


Appendix B. Concentrations of minor constituents in Biscuit Brook water samples, April 1983 through September 1985 (continued).

[Concentrations in microequivalents per liter;

$\mathrm{DOC}=$ dissolved organic carbon, ${ }^{\circ} \mathrm{C}=$ degrees Celcius]

\begin{tabular}{|c|c|c|c|c|c|c|c|c|c|}
\hline \multirow[b]{2}{*}{$\begin{array}{l}\text { Year } \\
\mathrm{PO}_{4}\end{array}$} & \multirow[b]{2}{*}{ Month } & \multirow[b]{2}{*}{ Day } & \multirow[b]{2}{*}{ Time } & \multirow[b]{2}{*}{$\begin{array}{l}\text { Temp } \\
\left({ }^{\circ} \mathrm{C}\right)\end{array}$} & \multicolumn{5}{|c|}{ Constituents } \\
\hline & & & & & Al & Ee & $M n$ & si & DOC \\
\hline
\end{tabular}

1984 (continued)

\begin{tabular}{rrrrrrr|rrrr}
84 & 11 & 5 & 851 & 8.0 & 50 & 8.0 & 7.0 & 1.9 & 4.2 & 0.00 \\
84 & 11 & 5 & 1000 & 8.0 & 50 & 7.0 & 8.0 & 2.0 & 3.6 & 0.00 \\
84 & 11 & 5 & 1110 & 8.0 & 50 & 7.0 & 8.0 & 2.1 & 4.5 & 0.00 \\
84 & 11 & 5 & 1200 & 8.0 & 50 & 6.0 & 9.0 & 2.1 & 3.4 & 0.00 \\
84 & 11 & 5 & 1235 & 8.5 & 50 & 6.0 & 9.0 & 2.1 & 3.2 & 0.00 \\
84 & 11 & 5 & 1310 & 9.0 & 40 & 6.0 & 7.0 & 2.2 & 3.1 & 0.00 \\
84 & 11 & 5 & 1410 & 9.0 & 40 & 5.0 & 6.0 & 2.2 & 3.2 & 0.00 \\
84 & 11 & 5 & 1540 & 9.0 & 40 & 6.0 & 8.0 & 2.2 & 2.6 & 0.00 \\
84 & 11 & 12 & 0 & - & 30 & 3.0 & 7.0 & 2.1 & - & 0.00 \\
84 & 11 & 21 & 1530 & - & 30 & 3.0 & 4.0 & 2.0 & 1.8 & 0.00 \\
84 & 11 & 27 & 1400 & 3.5 & 30 & 3.0 & 3.0 & 1.8 & 0.9 & 0.00 \\
84 & 11 & 29 & 1355 & - & 150 & 13.0 & 53.0 & 2.1 & 4.1 & 0.00 \\
84 & 12 & 5 & 1550 & 1.0 & 40 & 3.0 & 4.0 & 2.4 & 1.6 & 0.00 \\
84 & 12 & 12 & 730 & 2.0 & 30 & 3.0 & 1.0 & 2.2 & 1.4 & 0.00 \\
84 & 12 & 18 & 1040 & 3.0 & 60 & 3.0 & 4.0 & 1.9 & - & 0.00 \\
84 & 12 & 22 & 800 & - & 70 & 5.0 & 14.0 & 1.5 & - & 0.00
\end{tabular}

1985

$\begin{array}{rrrrlrlllll}85 & 1 & 1 & 1345 & 3.0 & 60 & 7.0 & 7.0 & 2.2 & - & 0.00 \\ 85 & 1 & 8 & 1300 & 1.0 & 40 & 5.0 & 5.0 & 2.2 & - & 0.00 \\ 85 & 1 & 15 & 1245 & 2.0 & 30 & 3.0 & 4.0 & 2.1 & - & 0.00 \\ 85 & 1 & 21 & 1745 & 0 . & 40 & 3.0 & 1.0 & 2.0 & 1.3 & 0.00 \\ 85 & 1 & 29 & 915 & 2.0 & 30 & 3.0 & 1.0 & 2.4 & - & 0.00 \\ 85 & 2 & 5 & 1010 & 1.5 & 20 & 6.0 & 4.0 & 2.4 & - & 0.00 \\ 85 & 2 & 12 & 1055 & 1.0 & 10 & 3.0 & 1.0 & 2.4 & - & 0.00 \\ 85 & 2 & 19 & 930 & - & 25 & 2.0 & 2.1 & 2.3 & 0.8 & 0.00 \\ 85 & 2 & 23 & 945 & 0 . & 30 & 3.0 & 1.0 & 2.1 & - & 0.01 \\ 85 & 2 & 23 & 1440 & 0 . & 30 & 4.0 & 6.0 & 2.0 & - & 0.00 \\ 85 & 2 & 23 & 1900 & 0 . & 30 & 4.0 & 2.0 & 2.1 & - & 0.01 \\ 85 & 2 & 24 & 930 & 0 . & 40 & 4.0 & 7.0 & 2.1 & - & 0.00 \\ 85 & 2 & 24 & 1320 & 0 . & 50 & 4.0 & 6.0 & 2.0 & - & 0.00 \\ 85 & 2 & 24 & 2140 & 0.5 & 100 & 5.0 & 27.0 & 1.9 & 1.9 & 0.00 \\ 85 & 2 & 24 & 2355 & 0.5 & 110 & 8.0 & 34.0 & 1.9 & - & 0.01 \\ 85 & 2 & 25 & 410 & 0.5 & 130 & 8.0 & 49.0 & 1.9 & - & 0.01 \\ 85 & 2 & 25 & 945 & 0 . & 140 & 8.0 & 49.0 & 1.9 & - & 0.00 \\ 85 & 2 & 25 & 1620 & 0.5 & 120 & 5.0 & 38.0 & 1.9 & - & 0.01 \\ 85 & 2 & 26 & 915 & 0.5 & 90 & 4.0 & 21.0 & 2.0 & - & 0.01 \\ 85 & 3 & 5 & 1045 & 2.0 & 63 & 2.0 & 13.0 & 1.9 & - & 0.00 \\ 85 & 3 & 5 & 1430 & - & 56 & 2.0 & 12.0 & 1.8 & - & 0.00 \\ 85 & 3 & 7 & 1410 & - & 38 & 1.0 & 10.0 & 2.0 & 1.8 & 0.00 \\ 85 & 3 & 11 & 2030 & 2.0 & 41 & 1.0 & 4.5 & 1.9 & 7.4 & 0.00 \\ 85 & 3 & 11 & 2230 & 2.0 & 40 & 1.0 & 4.5 & 1.9 & - & 0.00 \\ 85 & 3 & 12 & 330 & 1.0 & 56 & 1.0 & 13.0 & 1.8 & 1.6 & 0.00 \\ 85 & 3 & 12 & 330 & - & 55 & 5.4 & 13.0 & 1.8 & - & 0.00 \\ 85 & 3 & 12 & 415 & - & 120 & 8.3 & 32.0 & 1.8 & - & 0.00 \\ 85 & 3 & 12 & 930 & 0.5 & 110 & 4.8 & 31.0 & 1.6 & 2.6 & 0.00 \\ 85 & 3 & 12 & 930 & - & 110 & 6.7 & 31.0 & 1.6 & - & 0.00 \\ 85 & 3 & 12 & 1030 & - & 110 & 6.4 & 36.0 & 1.6 & - & 0.00\end{array}$


Appendix B. Concentrations of minor constituents in Biscuit Brook water samples, April 1983 through September 1985 (continued).

[Concentrations in microequivalents per liter;

$\mathrm{DOC}=$ dissolved organic carbon, ${ }^{\circ} \mathrm{C}=$ degrees Celcius]

\begin{tabular}{llllllll}
\hline Year Month & Day Time & Temp & Al & Fe & Mn & Si & DOC \\
$\mathrm{PO}_{4}$ & & & & & & \\
\hline
\end{tabular}

1985 (continued)

\begin{tabular}{|c|c|c|c|c|c|c|c|c|c|c|}
\hline 85 & 3 & 12 & 1130 & 0.5 & 120 & 7.8 & 40.0 & 1.7 & 9.9 & 0.00 \\
\hline 85 & 3 & 12 & 1230 & - & 130 & 6.6 & 42.0 & 1.7 & - & 0.00 \\
\hline 85 & 3 & 12 & 1300 & 1.0 & 49 & 4.9 & 10.0 & 1.8 & 1.2 & 0.00 \\
\hline 85 & 3 & 12 & 1410 & - & 150 & 5.9 & 47.0 & 1.7 & - & 0.00 \\
\hline 85 & 3 & 12 & 1510 & 1.5 & 140 & 8.2 & 48.0 & 1.7 & 2.2 & 0.00 \\
\hline 85 & 3 & 12 & 1610 & - & 150 & 6.2 & 48.0 & 1.7 & - & 0.00 \\
\hline 85 & 3 & 12 & 1705 & 1.5 & 130 & 2.0 & 45.0 & 1.7 & 2.4 & 0.00 \\
\hline 85 & 3 & 12 & 1810 & - & 140 & 6.0 & 44.0 & 1.7 & - & 0.00 \\
\hline 85 & 3 & 12 & 1905 & 1.0 & 140 & 8.6 & 41.0 & 1.8 & 2.8 & 0.00 \\
\hline 85 & 3 & 12 & 1905 & 1.0 & 140 & 8.6 & 41.0 & 1.8 & 2.8 & 0.00 \\
\hline 85 & 3 & 12 & 1910 & - & 140 & 5.9 & 42.0 & 1.8 & - & 0.00 \\
\hline 85 & 3 & 12 & 2110 & - & 140 & 6.1 & 41.0 & 1.8 & - & 0.00 \\
\hline 85 & 3 & 12 & 2220 & 1.0 & 130 & 6.8 & 37.0 & 1.8 & 2.0 & 0.00 \\
\hline 85 & 3 & 13 & 1015 & - & 110 & 4.8 & 27.0 & 1.8 & - & 0.00 \\
\hline 85 & 3 & 13 & 1030 & 1.8 & 94 & 3.1 & 23.0 & 2.0 & 1.6 & 0.00 \\
\hline 85 & 3 & 26 & 935 & 1.0 & 42 & 2.4 & 4.6 & 2.0 & - & 0.00 \\
\hline 85 & 3 & 29 & 545 & 4.5 & 130 & 6.2 & 32.0 & 1.7 & 2.5 & 0.00 \\
\hline 85 & 3 & 31 & 1600 & 2.8 & 79 & 1.0 & 14.0 & 1.7 & 1.7 & 0.00 \\
\hline 85 & 4 & 2 & 930 & 2.0 & 65 & 1.0 & 11.0 & 1.8 & - & 0.00 \\
\hline 85 & 4 & 9 & 915 & 2.0 & 50 & 3.0 & 10.0 & 1.9 & - & 0.00 \\
\hline 85 & 4 & 16 & 1130 & 7.0 & 50 & 3.0 & 5.0 & 1.8 & - & 0.00 \\
\hline 85 & 4 & 23 & 940 & 11.0 & 50 & 3.0 & 5.0 & 1.9 & - & 0.00 \\
\hline 85 & 4 & 30 & 940 & 7.0 & 30 & 3.0 & 1.0 & 1.8 & - & 0.00 \\
\hline 85 & 5 & 3 & 730 & - & 63 & 2.5 & 5.3 & 1.7 & - & 0.00 \\
\hline 85 & 5 & 3 & 1400 & - & 40 & 8.0 & 4.0 & 1.6 & - & 0.00 \\
\hline 85 & 5 & 7 & 0 & 9.0 & 40 & 3.0 & 1.0 & 1.8 & - & 0.00 \\
\hline 85 & 5 & 13 & 2000 & 14.5 & 42 & 2.0 & 5.3 & 1.9 & 1.9 & 0.00 \\
\hline 85 & 5 & 17 & 2315 & - & 40 & 3.0 & 3.0 & 1.9 & 1.5 & 0.00 \\
\hline 85 & 5 & 18 & 740 & - & 70 & 2.0 & 5.9 & 2.1 & 2.0 & 0.00 \\
\hline 85 & 5 & 18 & 1155 & 10.5 & 74 & 2.0 & 6.4 & 2.0 & - & 0.00 \\
\hline 85 & 5 & 18 & 1815 & 10.8 & 100 & 3.0 & 9.0 & 2.0 & 2.4 & 0.00 \\
\hline 85 & 5 & 19 & 1540 & 10.0 & 55 & 2.0 & 5.0 & 2.0 & - & 0.00 \\
\hline 85 & 5 & 21 & 1000 & 10.0 & 39 & 2.0 & 3.2 & 2.0 & - & 0.00 \\
\hline 85 & 5 & 28 & 1030 & - & 40 & 3.0 & 2.0 & 2.0 & - & 0.00 \\
\hline 85 & 6 & 4 & 925 & - & 40 & 2.0 & 1.4 & 2.2 & - & 0.00 \\
\hline 85 & 6 & 29 & 2230 & - & 55 & 5.2 & 1.0 & 2.1 & - & 0.00 \\
\hline 85 & 7 & 16 & 945 & - & 90 & 5.0 & 7.0 & 1.9 & 2.3 & 0.00 \\
\hline 85 & 7 & 23 & 1055 & 13.0 & 40 & 4.5 & 1.0 & 2.5 & - & 0.00 \\
\hline 85 & 7 & 31 & 1140 & - & 40 & 6.0 & 4.0 & 2.3 & 1.7 & 0.00 \\
\hline 85 & 7 & 31 & 1515 & - & 40 & 4.0 & 4.0 & 2.1 & - & 0.00 \\
\hline 85 & 7 & 31 & 1715 & - & 60 & 12.0 & 5.0 & 2.0 & - & 0.00 \\
\hline 85 & 7 & 31 & 1730 & - & 50 & 13.0 & 5.0 & 2.1 & 2.3 & 0.00 \\
\hline 85 & 7 & 31 & 1930 & - & 130 & 10.0 & 15.0 & 0.3 & - & 0.00 \\
\hline 85 & 7 & 31 & 2215 & - & 100 & 13.0 & 9.0 & 1.8 & - & 0.00 \\
\hline 85 & 7 & 31 & 2230 & - & 90 & 13.0 & 10.0 & 1.9 & - & 0.00 \\
\hline 85 & 8 & 1 & 630 & - & 80 & 7.0 & 6.0 & 1.9 & 2.8 & 0.00 \\
\hline 85 & 8 & 13 & 1004 & 13.0 & 32 & 2.0 & 1.0 & 2.5 & - & 0.00 \\
\hline 85 & 8 & 27 & 0 & 15.0 & 35 & 2.0 & 1.2 & 2.4 & - & 0.00 \\
\hline 85 & 9 & 10 & 940 & 15.0 & 50 & 2.1 & 2.0 & 2.4 & - & 0.00 \\
\hline
\end{tabular}


$[\mathrm{mL}=\mathrm{milliliters.} \mu \mathrm{s} / \mathrm{cm}=$ microsiemens per square centimeter. Concentrations in microequivalents per liter.]

\begin{tabular}{|c|c|c|c|c|c|c|c|c|c|c|c|c|c|}
\hline \multirow[b]{2}{*}{ Year } & \multirow[b]{2}{*}{ Month } & \multirow[b]{2}{*}{ Day } & \multirow[b]{2}{*}{$\begin{array}{c}\text { Sample } \\
\text { volume } \\
\text { (mL) }\end{array}$} & \multirow[b]{2}{*}{$\mathrm{pH}$} & \multirow[b]{2}{*}{$\begin{array}{l}\text { Specific } \\
\text { conduc- } \\
\text { tance } \\
(\mu \mathrm{s} / \mathrm{cm})\end{array}$} & & \multicolumn{7}{|c|}{ Constituent or Characterlstic } \\
\hline & & & & & & $\mathrm{Ca}$ & $\mathrm{Mg}$ & $\mathrm{Na}$ & $\mathbf{K}$ & $\mathrm{NH}_{4}$ & $\mathrm{SO}_{4}$ & $\mathrm{NO}_{3}$ & Cl \\
\hline \multicolumn{14}{|l|}{1983} \\
\hline $\begin{array}{l}83 \\
83 \\
83 \\
83 \\
83 \\
83 \\
83 \\
83 \\
83 \\
83 \\
83 \\
83 \\
83\end{array}$ & $\begin{array}{l}10 \\
10 \\
10 \\
10 \\
11 \\
11 \\
11 \\
11 \\
11 \\
12 \\
12 \\
12 \\
12\end{array}$ & $\begin{array}{r}4 \\
11 \\
18 \\
25 \\
1 \\
8 \\
15 \\
22 \\
29 \\
6 \\
13 \\
20 \\
27\end{array}$ & $\begin{array}{l}0.5 \\
0.9 \\
1.5 \\
0.1 \\
0.1 \\
1.1 \\
1.6 \\
2.5 \\
0.7 \\
2.8 \\
1.0 \\
2.5 \\
0.0\end{array}$ & $\begin{array}{l}4.2 \\
4.5 \\
4.7 \\
4.2 \\
5.9 \\
4.5 \\
4.6 \\
4.5 \\
4.6 \\
4.6 \\
5.1 \\
4.9 \\
4.0\end{array}$ & $\begin{array}{r}0.0 \\
15.7 \\
9.7 \\
29.0 \\
2.6 \\
11.6 \\
11.7 \\
11.5 \\
9.3 \\
10.5 \\
4.6 \\
7.8 \\
59.6\end{array}$ & 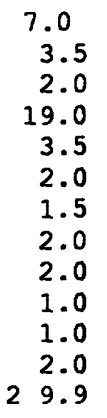 & $\begin{array}{c}3.5 \\
3.2 \\
0.6 \\
7.0 \\
1.4 \\
0.7 \\
1.3 \\
0.7 \\
1.0 \\
1.6 \\
2.5 \\
0.8 \\
8.8\end{array}$ & $\begin{array}{r}4.0 \\
11.5 \\
1.2 \\
13.9 \\
2.4 \\
1.2 \\
4.0 \\
3.1 \\
1.6 \\
6.0 \\
10.1 \\
1.6 \\
20.8\end{array}$ & $\begin{array}{l}1.0 \\
1.2 \\
0.1 \\
2.7 \\
0.7 \\
0.4 \\
0.3 \\
1.1 \\
0.4 \\
0.2 \\
0.2 \\
0.7 \\
2.0\end{array}$ & $\begin{array}{r}32.7 \\
7.8 \\
1.1 \\
9.4 \\
2.8 \\
1.1 \\
2.8 \\
4.4 \\
4.4 \\
1.1 \\
1.1 \\
3.3 \\
12.2\end{array}$ & $\begin{array}{r}65.9 \\
21.0 \\
16.2 \\
63.2 \\
2.1 \\
17.1 \\
20.0 \\
20.2 \\
15.6 \\
18.7 \\
13.3 \\
15.8 \\
50.8\end{array}$ & $\begin{array}{r}46.4 \\
17.7 \\
10.3 \\
34.1 \\
1.3 \\
11.1 \\
12.2 \\
11.6 \\
16.6 \\
11.1 \\
3.5 \\
8.4 \\
113.0\end{array}$ & $\begin{array}{r}4.5 \\
12.7 \\
2.0 \\
10.7 \\
2.8 \\
2.3 \\
5.4 \\
3.9 \\
3.1 \\
7.0 \\
11.0 \\
3.1 \\
21.4\end{array}$ \\
\hline \multicolumn{14}{|l|}{1984} \\
\hline $\begin{array}{l}84 \\
84 \\
84 \\
84 \\
84 \\
84 \\
84 \\
84 \\
84 \\
84\end{array}$ & $\begin{array}{l}1 \\
1 \\
1 \\
1 \\
1 \\
2 \\
2 \\
2 \\
2 \\
3\end{array}$ & $\begin{array}{r}3 \\
10 \\
17 \\
24 \\
31 \\
7 \\
14 \\
21 \\
28 \\
6\end{array}$ & $\begin{array}{l}1.0 \\
1.2 \\
0.5 \\
1.0 \\
1.3 \\
0.3 \\
2.2 \\
0.7 \\
1.2 \\
1.3\end{array}$ & $\begin{array}{l}4.0 \\
4.3 \\
4.2 \\
4.2 \\
4.1 \\
3.9 \\
4.2 \\
4.3 \\
4.2 \\
5.0\end{array}$ & $\begin{array}{r}52.1 \\
26.4 \\
33.4 \\
28.0 \\
28.7 \\
64.7 \\
33.9 \\
19.7 \\
22.1 \\
5.0\end{array}$ & $\begin{array}{r}5.0 \\
3.0 \\
3.5 \\
2.5 \\
2.5 \\
15.5 \\
5.5 \\
7.0 \\
5.5 \\
9.0\end{array}$ & $\begin{array}{r}1.9 \\
3.1 \\
3.5 \\
1.5 \\
1.8 \\
10.8 \\
9.7 \\
2.1 \\
1.7 \\
3.1\end{array}$ & $\begin{array}{r}5.4 \\
9.5 \\
13.3 \\
4.9 \\
4.5 \\
29.4 \\
39.7 \\
3.1 \\
1.7 \\
5.2\end{array}$ & $\begin{array}{l}0.9 \\
0.6 \\
1.5 \\
0.3 \\
0.4 \\
1.5 \\
1.2 \\
0.6 \\
2.0 \\
1.3\end{array}$ & $\begin{array}{r}27.7 \\
6.7 \\
6.7 \\
7.2 \\
20.0 \\
33.3 \\
9.4 \\
10.5 \\
6.7 \\
3.3\end{array}$ & $\begin{array}{r}53.7 \\
32.9 \\
47.0 \\
43.5 \\
43.5 \\
102.5 \\
43.3 \\
40.6 \\
37.2 \\
11.2\end{array}$ & $\begin{array}{r}81.3 \\
31.4 \\
33.3 \\
28.0 \\
31.9 \\
80.2 \\
27.9 \\
24.5 \\
22.9 \\
6.9\end{array}$ & $\begin{array}{r}9.6 \\
13.3 \\
13.5 \\
5.9 \\
7.3 \\
33.3 \\
46.2 \\
4.2 \\
2.8 \\
6.8\end{array}$ \\
\hline $\begin{array}{l}84 \\
84 \\
84 \\
84 \\
84 \\
84 \\
84 \\
84 \\
84 \\
84\end{array}$ & $\begin{array}{l}3 \\
3 \\
3 \\
4 \\
4 \\
4 \\
4 \\
5 \\
5 \\
5\end{array}$ & $\begin{array}{r}13 \\
20 \\
27 \\
3 \\
10 \\
17 \\
24 \\
1 \\
8 \\
15\end{array}$ & $\begin{array}{l}0.2 \\
0.4 \\
1.9 \\
3.8 \\
2.3 \\
1.2 \\
0.3 \\
1.9 \\
1.6 \\
0.5\end{array}$ & $\begin{array}{l}3.2 \\
4.0 \\
4.4 \\
4.5 \\
4.4 \\
3.7 \\
3.5 \\
4.4 \\
4.1 \\
3.9\end{array}$ & $\begin{array}{r}302.0 \\
42.5 \\
19.5 \\
14.3 \\
16.1 \\
70.5 \\
102.0 \\
13.3 \\
25.7 \\
47.0\end{array}$ & $\begin{array}{ll}9 & 5.8 \\
1 & 3.5 \\
1 & 0.0 \\
& 3.0 \\
1 & 0.5 \\
2 & 4.5 \\
9 & 3.3 \\
& 9.0 \\
2 & 3.0 \\
4 & 5.9\end{array}$ & $\begin{array}{r}64.2 \\
7.2 \\
4.4 \\
1.0 \\
1.6 \\
4.7 \\
29.1 \\
4.9 \\
8.3 \\
17.9\end{array}$ & $\begin{array}{r}45.7 \\
14.5 \\
3.8 \\
1.2 \\
1.5 \\
1.4 \\
20.7 \\
11.8 \\
5.2 \\
7.0\end{array}$ & $\begin{array}{r}12.3 \\
0.9 \\
0.8 \\
0.2 \\
0.1 \\
0.7 \\
37.4 \\
1.2 \\
12.6 \\
24.3\end{array}$ & $\begin{array}{r}57.2 \\
15.5 \\
1.7 \\
3.3 \\
2.2 \\
13.3 \\
632.7 \\
25.0 \\
83.2 \\
184.8\end{array}$ & $\begin{array}{r}493.0 \\
72.4 \\
25.4 \\
24.1 \\
22.3 \\
103.2 \\
445.1 \\
45.8 \\
87.6 \\
200.1\end{array}$ & $\begin{array}{r}243.1 \\
45.4 \\
32.7 \\
10.9 \\
20.3 \\
77.8 \\
191.6 \\
18.2 \\
49.7 \\
89.0\end{array}$ & $\begin{array}{r}5.9 \\
17.5 \\
3.9 \\
2.3 \\
2.3 \\
3.7 \\
23.7 \\
3.4 \\
7.3 \\
11.8\end{array}$ \\
\hline $\begin{array}{l}84 \\
84 \\
84 \\
84 \\
84 \\
84 \\
84 \\
84 \\
84 \\
84\end{array}$ & $\begin{array}{l}5 \\
5 \\
6 \\
6 \\
6 \\
6 \\
7 \\
7 \\
7 \\
7\end{array}$ & $\begin{array}{r}22 \\
29 \\
5 \\
12 \\
19 \\
26 \\
3 \\
10 \\
17 \\
24\end{array}$ & $\begin{array}{l}4.5 \\
1.7 \\
0.7 \\
0.7 \\
1.5 \\
1.9 \\
1.1 \\
1.3 \\
1.0 \\
1.3\end{array}$ & $\begin{array}{r}4.4 \\
4.3 \\
14.0 \\
3.9 \\
4.9 \\
4.3 \\
4.0 \\
3.9 \\
3.9 \\
3.7\end{array}$ & $\begin{array}{c}15.8 \\
18.3 \\
0 . \\
55.7 \\
14.0 \\
15.9 \\
37.0 \\
45.5 \\
48.6 \\
59.3\end{array}$ & $\begin{array}{ll} & 4.0 \\
& 7.5 \\
& 0 . \\
1 & 0.5 \\
1 & 6.5 \\
& 2.0 \\
& 2.3 \\
& 4.5 \\
7.8 \\
\\
9.8\end{array}$ & $\begin{array}{l}2.5 \\
5.7 \\
0 . \\
5.2 \\
5.8 \\
1.5 \\
1.7 \\
1.6 \\
2.3 \\
3.2\end{array}$ & $\begin{array}{l}2.2 \\
1.4 \\
0 . \\
3.3 \\
9.6 \\
0.3 \\
1.4 \\
1.1 \\
0.9 \\
1.5\end{array}$ & $\begin{array}{l}2.1 \\
7.8 \\
0 . \\
4.2 \\
8.7 \\
0.4 \\
0.8 \\
0.5 \\
0.9 \\
1.1\end{array}$ & $\begin{array}{c}7.8 \\
1.7 \\
0 . \\
21.1 \\
0 . \\
6.1 \\
14.4 \\
21.1 \\
29.4 \\
15.0\end{array}$ & $\begin{array}{c}28.9 \\
34.5 \\
0 . \\
94.6 \\
33.7 \\
24.8 \\
67.4 \\
91.7 \\
91.3 \\
82.8\end{array}$ & $\begin{array}{c}16.7 \\
19.0 \\
0 . \\
60.9 \\
2.3 \\
18.2 \\
29.9 \\
28.5 \\
44.0 \\
73.1\end{array}$ & $\begin{array}{l}3.4 \\
3.1 \\
0 . \\
3.4 \\
15.2 \\
3.1 \\
3.1 \\
3.4 \\
3.9 \\
5.9\end{array}$ \\
\hline $\begin{array}{l}84 \\
84 \\
84 \\
84 \\
84 \\
84 \\
84 \\
84 \\
84\end{array}$ & $\begin{array}{l}7 \\
8 \\
8 \\
8 \\
8 \\
9 \\
9 \\
9 \\
9\end{array}$ & $\begin{array}{r}31 \\
7 \\
14 \\
21 \\
28 \\
4 \\
11 \\
18 \\
25\end{array}$ & $\begin{array}{l}0.6 \\
0.7 \\
0.5 \\
0.5 \\
0.9 \\
0.9 \\
0.6 \\
0.0 \\
0.6\end{array}$ & $\begin{array}{r}4.0 \\
3.6 \\
3.8 \\
14.0 \\
4.1 \\
14.0 \\
4.0 \\
3.7 \\
4.2\end{array}$ & $\begin{array}{c}33.5 \\
95.0 \\
4.7 \\
0 . \\
21.1 \\
0 . \\
23.8 \\
46.2 \\
15.5\end{array}$ & $\begin{array}{c}10.0 \\
7.6 \\
7.1 \\
0 . \\
2.7 \\
0 . \\
16.2 \\
32.2 \\
4.3\end{array}$ & $\begin{array}{l}3.9 \\
8.6 \\
5.8 \\
0 . \\
1.7 \\
0 . \\
9.0 \\
20.8 \\
2.3\end{array}$ & $\begin{array}{l}2.2 \\
8.2 \\
2.7 \\
0 . \\
3.2 \\
0 . \\
9.8 \\
19.2 \\
2.4\end{array}$ & $\begin{array}{l}2.3 \\
1.6 \\
1.2 \\
0 . \\
0.4 \\
0 . \\
1.7 \\
2.0 \\
0.4\end{array}$ & $\begin{array}{c}42.7 \\
40.0 \\
1.1 \\
0 . \\
10.5 \\
0 . \\
2.8 \\
40.0 \\
2.8\end{array}$ & $\begin{array}{c}85.1 \\
180.1 \\
15.6 \\
0 . \\
32.4 \\
0 . \\
50.8 \\
129.6 \\
22.7\end{array}$ & $\begin{array}{c}27.0 \\
80.7 \\
0.3 \\
0 . \\
22.7 \\
0 . \\
19.0 \\
55.9 \\
19.2\end{array}$ & $\begin{array}{l}3.4 \\
9.9 \\
5.1 \\
0 . \\
4.2 \\
0 . \\
7.9 \\
11.6 \\
2.5\end{array}$ \\
\hline
\end{tabular}


Appendix C. Concentrations of major constituents of weekly precipitation samples from the National Trends Network Monitoring station at Biscuit Brook. October 1983 through September 1985 (continued).

$[\mathrm{mL}=\mathrm{milliliters} . \mu \mathrm{s} / \mathrm{cm}=$ microsiemens per square centimeter. Concentrations in microequivalents per liter.]

\begin{tabular}{|c|c|c|c|c|c|c|c|c|c|c|c|c|c|}
\hline \multirow[b]{2}{*}{ Year } & \multirow[b]{2}{*}{ Month } & \multirow[b]{2}{*}{ Day } & \multirow[b]{2}{*}{$\begin{array}{c}\text { Sample } \\
\text { volume } \\
\text { (mL) }\end{array}$} & \multirow[b]{2}{*}{$\mathrm{pH}$} & \multirow[b]{2}{*}{$\begin{array}{l}\text { Specific } \\
\text { conduc- } \\
\text { tance } \\
(\mu \mathrm{S} / \mathrm{cm})\end{array}$} & \multicolumn{8}{|c|}{ Const ituent or Characteristic } \\
\hline & & & & & & $\mathrm{Ca}$ & Mg & $\mathrm{Na}$ & $\mathbf{K}$ & $\mathrm{NH}_{4}$ & $\mathrm{SO}_{4}$ & $\mathrm{NO}_{3}$ & $\mathrm{Cl}$ \\
\hline
\end{tabular}

1984 (continued)

\begin{tabular}{|c|c|c|c|c|c|c|c|c|c|c|c|c|c|}
\hline 84 & 10 & 2 & 0.3 & 4.0 & 35.6 & 39.0 & 12.1 & 3.3 & 1.7 & 52.7 & 90.3 & 59.4 & 5.9 \\
\hline 84 & 10 & 9 & 0 . & 5.5 & 2.6 & 5.0 & 2.9 & 1.6 & 1.0 & 1.1 & 6.2 & 0.3 & 2.0 \\
\hline 84 & 10 & 16 & 1.3 & 4.2 & 31.0 & 1.9 & 1.2 & 1.7 & 0.5 & 21.1 & 51.4 & 33.6 & 3.1 \\
\hline 84 & 10 & 23 & 0.3 & 4.2 & 31.0 & 1.9 & 1.2 & 1.7 & 0.5 & 21.1 & 51.4 & 33.6 & 3.1 \\
\hline 84 & 10 & 30 & 0.9 & 4.6 & 17.0 & 2.1 & 3.1 & 9.2 & 0.5 & 6.1 & 33.1 & 15.3 & 9.6 \\
\hline 84 & 11 & 6 & 0.9 & 4.2 & 29.0 & 3.7 & 3.0 & 8.5 & 0.6 & 12.2 & 45.3 & 34.1 & 8.7 \\
\hline 84 & 11 & 13 & 0.0 & 4.2 & 43.1 & 36.7 & 19.3 & 16.8 & 1.8 & 34.4 & 101.5 & 69.1 & 8.2 \\
\hline 84 & 11 & 20 & 0. & 14.0 & 0 & 0 & 0 & 0 & 0. & 0 & 0 & 0 & 0. \\
\hline 84 & 11 & 27 & 3.3 & 4.8 & 0. & 11.7 & 6.0 & 8.4 & 1.5 & 3.6 & 12.3 & 6.6 & 9.2 \\
\hline 84 & 12 & 4 & 0.6 & 4.6 & 12.7 & 5.0 & 4.8 & 2.9 & 1.8 & 4.4 & 16.2 & 24.3 & 3.7 \\
\hline 84 & 12 & 11 & 0.3 & 3.9 & 50.0 & 12.8 & 9.9 & 14.7 & 4.0 & 15.5 & 88.2 & 59.2 & 13.3 \\
\hline 84 & 12 & 18 & 2.1 & 4.3 & 23.3 & 2.0 & 1.3 & 2.8 & 0.3 & 0.8 & 38.7 & 21.3 & 3.9 \\
\hline 84 & 12 & 25 & 0. & 14.0 & 0 & 0 & 0. & 0. & 0. & 0 & 0 & 0 & 0. \\
\hline
\end{tabular}

1985

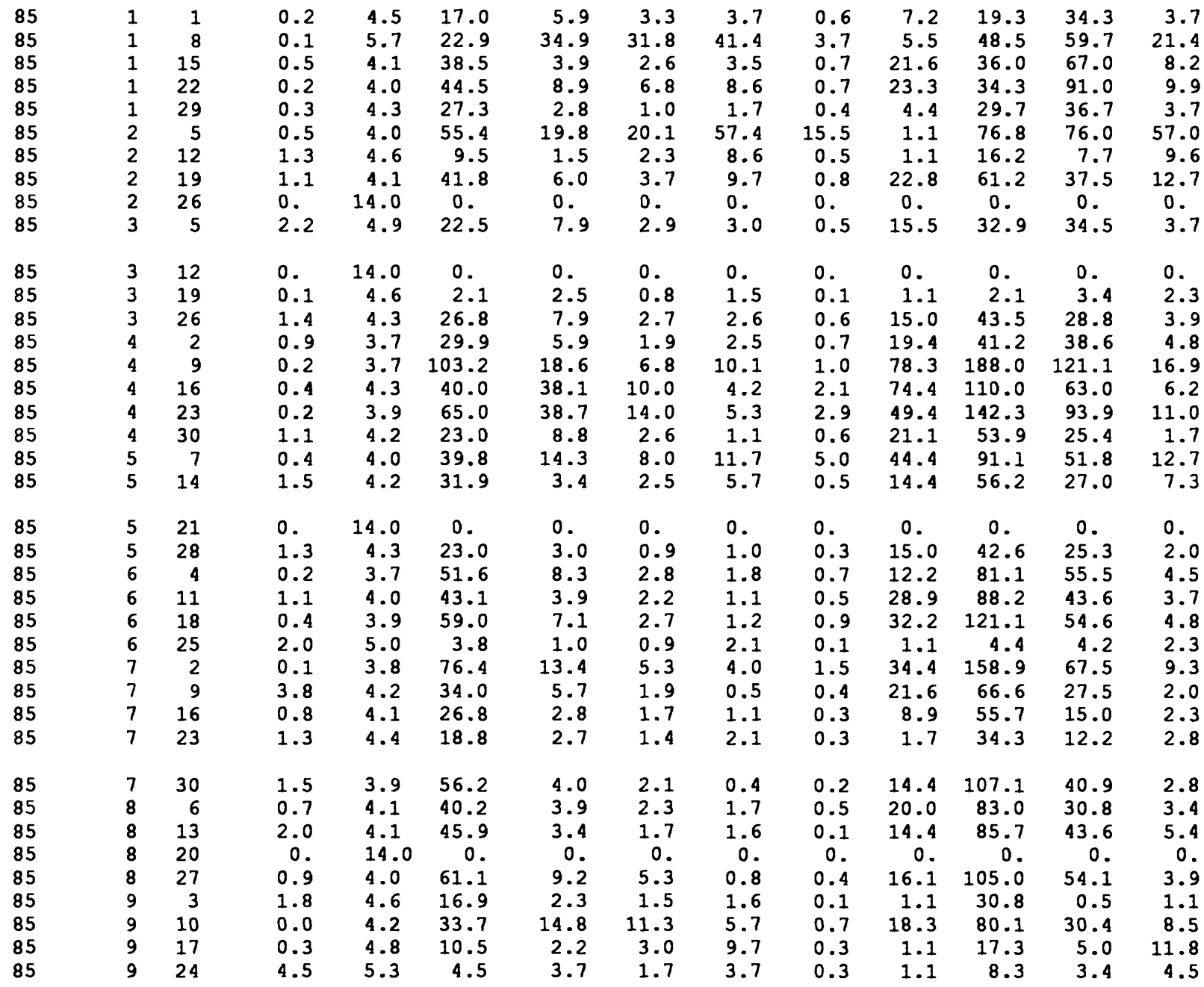




\section{ASSESSMENT OF DATA QUALITY}

All laboratories participating in this study met the criteria for a U.S. Environmental protection Agency (USEPA) certified laboratory and have strict internal quality-control programs (Fishman and Friedman, 1985; Finkelstein and others, 1984; Peart and Thomas, 1984). A special "low-ionic-strength medium" group was established at the U.S. Geological survey (USGS) laboratory in Denver, Colo., to deal specifically with low-ionic-strength waters. Ion chromatography equipment used at the USGS laboratory in Albany, N.Y., during the latter part of the study was also designated for low-ionic-strength samples only, and both $\mathrm{pH}$ and conductance electrodes used were specifically designed for dilute-solution analyses. The quality-control program for this study included several method-verification experiments in addition to the standard quality-control procedures, which included duplicate samples for 10 percent of the samples taken and quarterly audit samples for testing both field and laboratory precision. The following is a discussion of the results of that program.

\section{Audit and Duplicate Samples}

Results of the USEPA audit-sample program suggest close agreement between results from analyses at the USGS laboratory and theoretical concentrations in control samples provided by Radion Corporation (table D-1, p. 60). Slightly lower concentrations of metals were observed in the field audit samples than in the control samples, probably because $0.1-\mu$ filters were used on the field audits. Studies have shown that the 0.4- and $0.2-\mu$ filters used for the control samples may not provide adequate removal of metal-bearing particulates for dissolved-constituent analysis (Kennedy and others, 1974). Preprocessed laboratory audit samples were delivered from USEPA to field personnel in bottles that would have easily been detected as test samples. These samples were therefore transfered to standard USGS bottles for shipment. The low manganese and iron concentrations (less than theoretical values) in these samples may be the result of this transfer, but consistency between the field and laboratory audit pairs suggest that this is not a source of error.

Results of the duplicate sample tests, presented in table D-2 (p. 61) and D-3 (p. 64), show generally satisfactory agreement between sample pairs. Sulfate variability appeared in analyses during mid-June 1985 but was corrected in reruns.

\section{Field Measurements}

Alkalinity was measured in the field immediately after sampling, and the Gran's plot technique was applied to compute values. Most samples were measured twice for field alkalinity, and if a significant difference was noted, a third measurement was made. Most replicate analyses gave the same results as the preceding ones, or nearly so. The standard error of 72 replicate analyses, with the data ranging from -32 to $140 \mu \mathrm{eq} / \mathrm{L}$, was 1.96 $\mu \mathrm{eq} / \mathrm{L}$. 
Extended storage of samples also did not appear to significantly alter alkalinty values (table D-4, p. 65). Repeated measurements of alkalinity on Maryland stream samples with initial values ranging from 100 to $1,000 \mu \mathrm{eq} / \mathrm{L}$ showed little change in concentration during 4 months of storage (M. M. Kennedy, U.S. Geological Survey, written commun., 1986). Catskill stream samples with alkalinity values ranging from 0 to $120 \mu \mathrm{eq} / \mathrm{L}$ and $\mathrm{lag}$ times of up to 9 months showed little or no change in alkalinity. Filtering also did not appear to affect alkalinity values or improve storability, even when samples had suspended sediment (table D-5, p. 66).

The plot of alkalinity against $\mathrm{pH}$ also suggests that field $\mathrm{pH}$ values are accurate. Results from an internal quality-control program, in which techniques and equipment used in $\mathrm{pH}$ measurement are tested on samples of known $\mathrm{pH}$, indicate that the $\mathrm{pH}$ measurements were satisfactory.

The effect of storage time on $\mathrm{pH}$ was not clear; some samples increased in $\mathrm{pH}$ with time, some decreased, and several showed no change. The variability was minor for even up to 1 year of storage, however (table D-4). Filtration of samples also did not appear to significantly alter $\mathrm{pH}$ values (table $\mathrm{D}-4)$. Differences in the lag time between sampling and analysis therefore did not affect comparability of samples.

The relation of specific conductance calculated from the sum of individual specific conductance (fig. D-1) values of all major ions to measured conductance indicates a good correlation $\left(R^{2}=0.66\right)$, considering the narrow range of values, and indicates that conductance, $\mathrm{pH}$, and major ions were measured accurately during the study.

\section{Laboratory Measurements}

More important than the duplicate-sample tests, the consistency of chemical correlations with flow and among constituents suggests good data quality. The quality of both field and laboratory data was assessed by anion-cation balances. Acidity as $\mathrm{H}+$ was calculated from field $\mathrm{pH}$ values for use in the balance, and field alkalinity values were used to calculate bicarbonate concentrations. The results of this balance suggest that both the field measurements and the laboratory measurements of major ions were satisfactory (fig. D1B). Of 198 samples taken, only five had an anion-to-cation ratio that deviated from the mean by more than 10 percent.

Minor constituents (aluminum, iron, manganese, silica, and dissolved organic carbon) had values within the expected range for streams draining sedimentary rock overlain by till (Hem, 1970) (see appendix B). Aluminum had an inverse relation to $\mathrm{pH}$, and this relation was similar among the streams studied. Samples analyzed after filtration through $0.1-\mu, 0.2-\mu$, and $0.4-\mu$ filters showed little or no difference in measured concentrations of major anions and cations. Results of filter pore-size tests on aluminum were inconclusive for low-concentration samples, but measured concentrations of aluminum were generally greater in aliquots of samples passed through larger pore sizes when concentrations were high (table D-6, p. 66). Variability among the filtered samples was highest during turbid, high-flow conditions. Therefore, some particulate materials probably passed through the $0.4-\mathrm{m}$ and 
$0.2-\mu$ filters during periods of high turbidity in the stream. Results of these tests were inconsistent, however. Because pore size did not affect major anion and cation concentrations, samples for all analyses were therefore passed through $0.1-\mu$ filters after the first year of the study.

\section{Discharge}

Discharge measurements were made by trained U.S. Geological Survey technicians at the time of sampling of each stream and are considered accurate. The accuracy of daily discharge data depends primarily on (1) the stability of the stage-vs.-discharge relation or, if the part of the stream controlling this relation is unstable, the frequency of discharge measurements, and (2) the accuracy of field measurements and the interpretations of records. Records collected and measurements made during January and February of both years were affected by ice in the stream and therefore may be less accurate. Rating curves of stream stage vs. discharge are considered valid for all flows at Biscuit Brook.

\section{Precipitation Volume and Chemistry}

For approximately 4 months of the first year of data collection, the wetfall-dryfall precipitation collector at Biscuit Brook was in bulk mode because of equipment malfunctions. An analysis of sample volume in relation to rainfall volume suggests that evaporation concentrated some of the samples. Most samples showed a good correlation between sample volume and precipitation volume, however $\left(r^{2}=0.85\right)$, which suggests that use of the bulk mode did not cause significant concentration of the samples.

The measurements of specific conductance and $\mathrm{pH}$ made in the field compare well with laboratory measurements for most samples (appendix C). A plot of field specific conductance against field $\mathrm{pH}$ shows a strong correlation that closely resembles the minimum conductance curve for water samples containing a strong acid (fig. D-1, p. 59). Likewise, the plot of field specific conductance against conductance calculated from the major ion concentrations show a strong correlation (fig. D-1). The ratio of calculated conductance to field conductance ranged from 0.79 to 1.23 , with an average deviation of 8.6 percent from the mean (1.00). The data suggest that mailing of samples for major-ion analyses did not affect sample quality.

When field $\mathrm{pH}$ values are used in cation calculations, an excellent balance of cations and anions results $\left(r^{2}=0.99\right)$ (fig. $\left.D-1\right)$. The standard error from an anion-to-cation ratio of 1.0 for 103 weeks of samples was 1.0 percent, and the ratio ranged from 0.78 to 1.19 . This suggests that measurements of anion and cation concentrations at the National Trends Network laboratory and measurements of $\mathrm{pH}$ and specific conductance in the field both produced precipitation data of good quality. 
STREAM SAMPLES
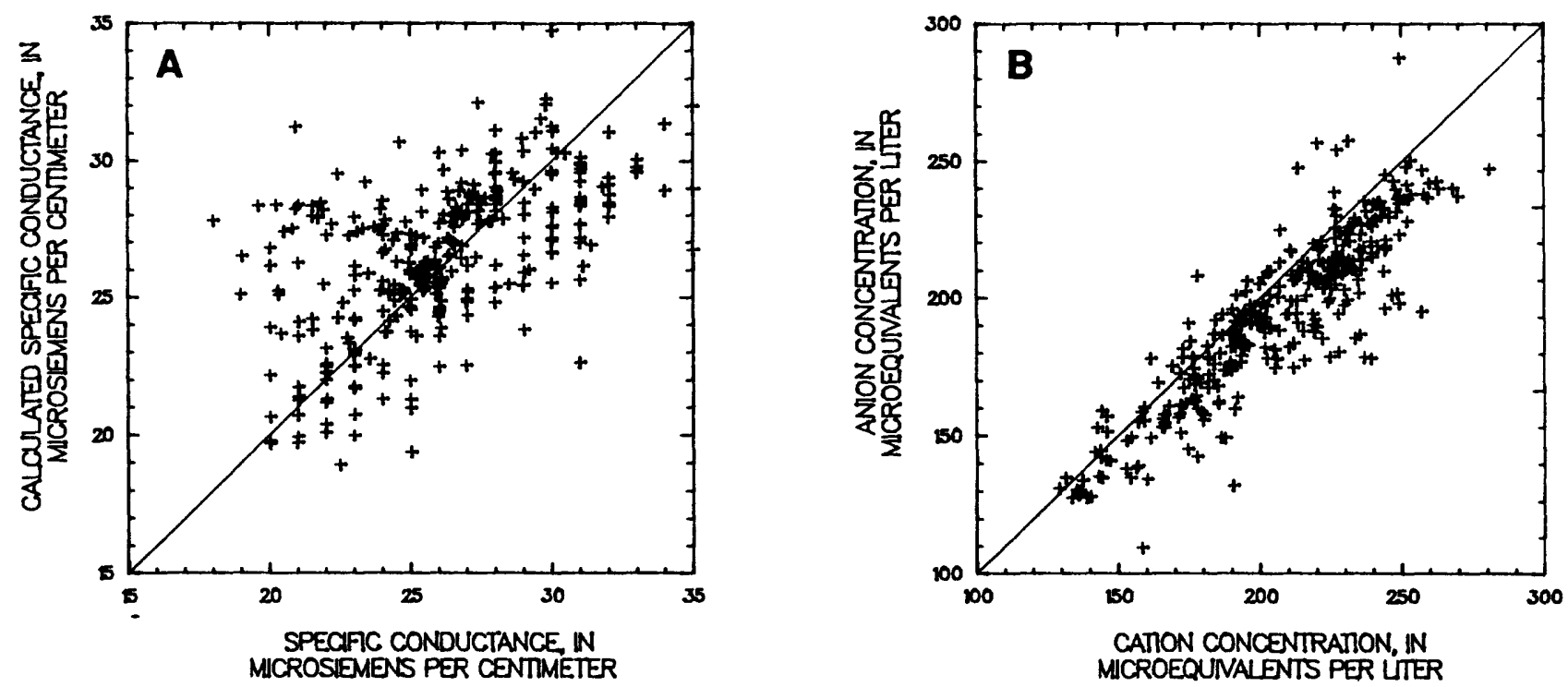

PRECIPITATION SAMPLES
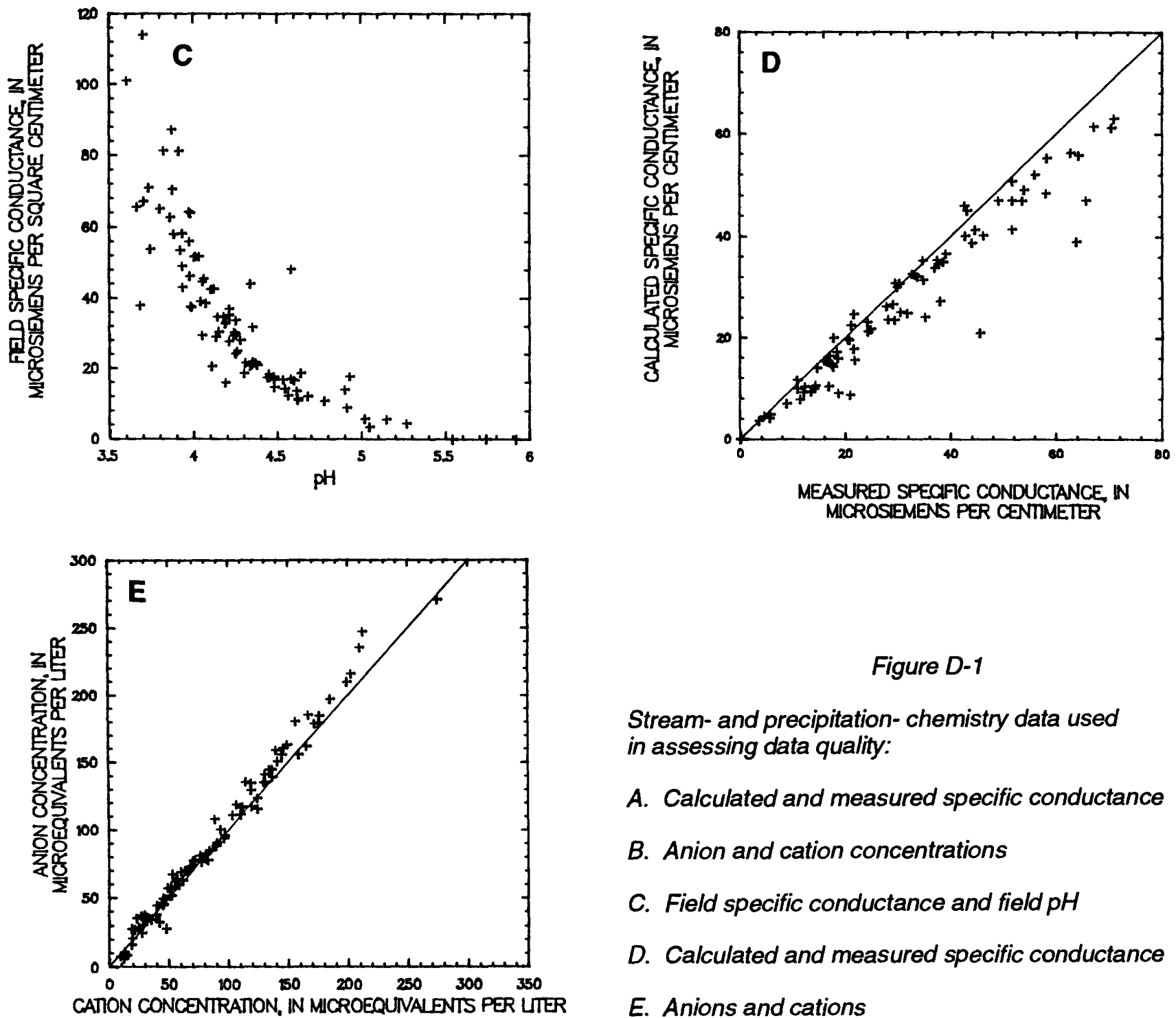

Figure D-1

Stream- and precipitation- chemistry data used in assessing data quality:
A. Calculated and measured specific conductance
B. Anion and cation concentrations
C. Field specific conductance and field $\mathrm{pH}$
D. Calculated and measured specific conductance
E. Anions and cations 


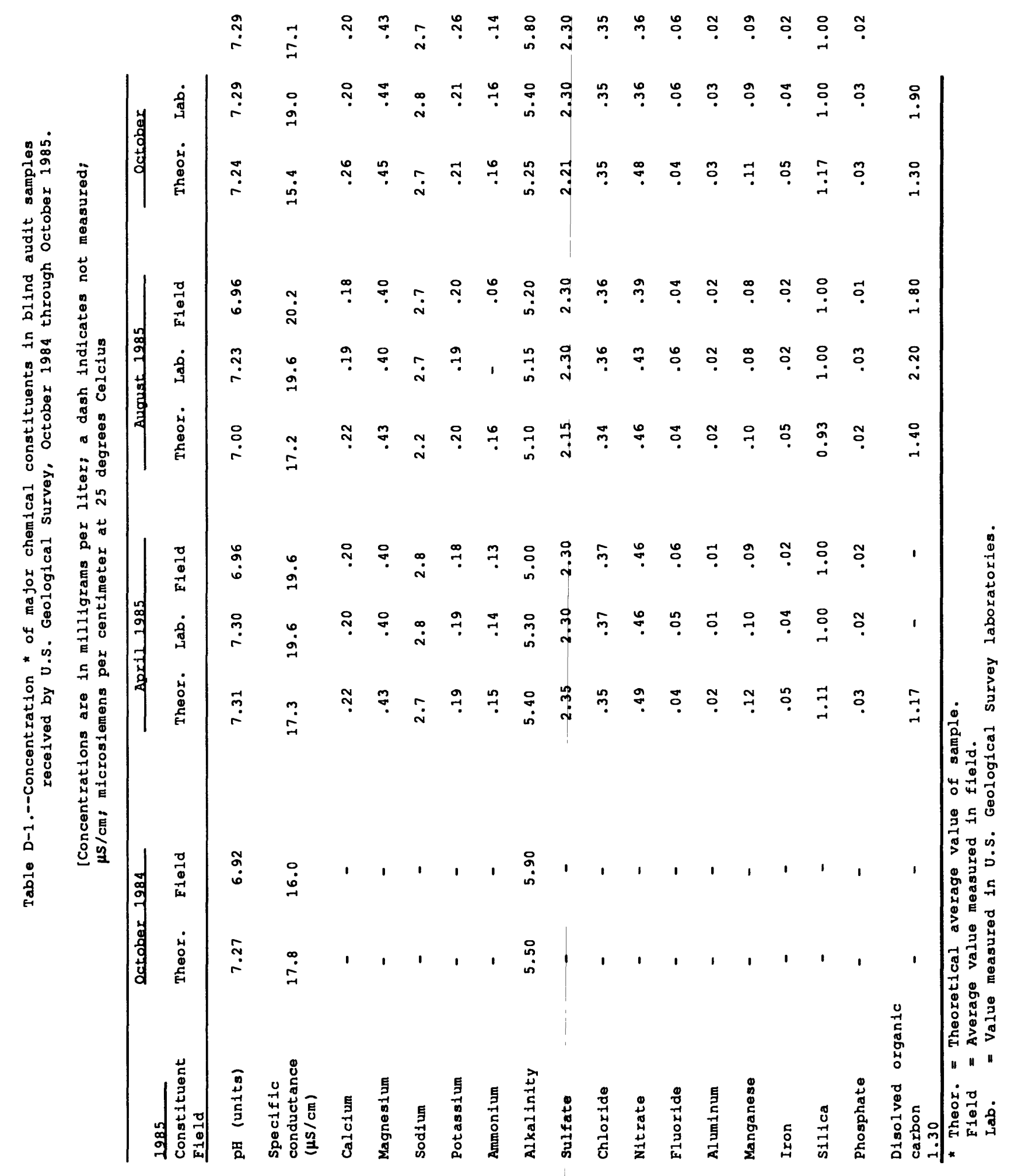




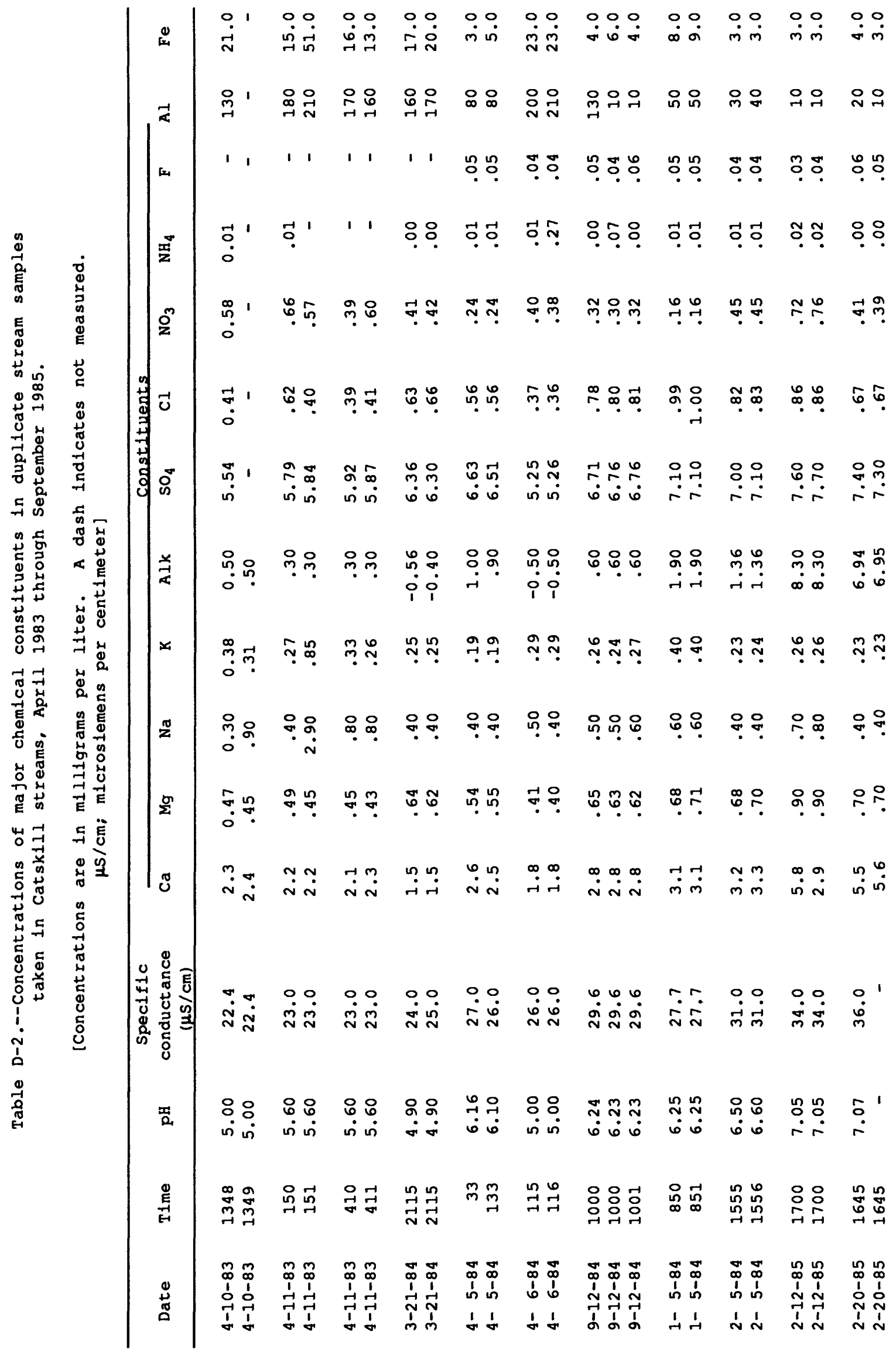




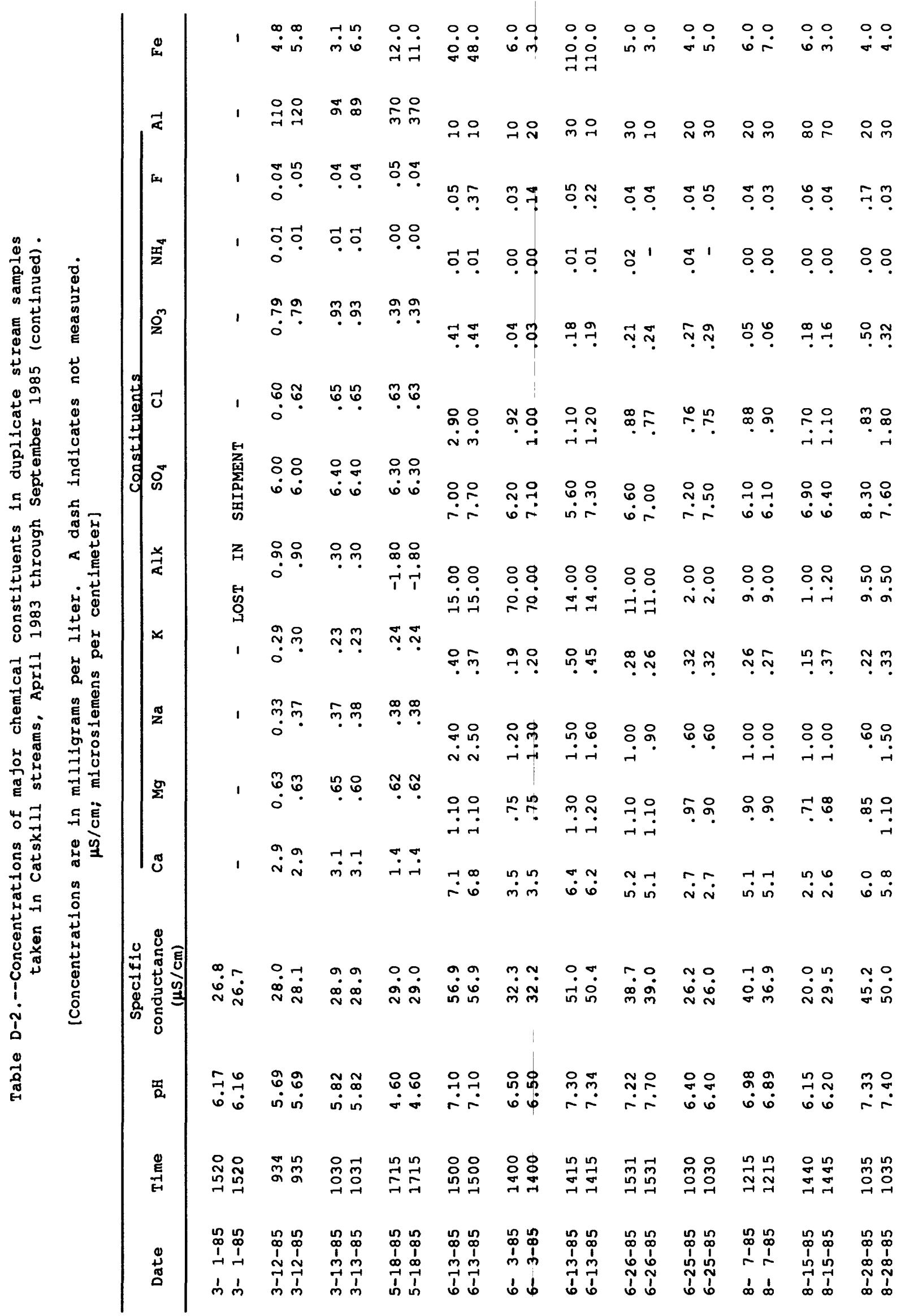




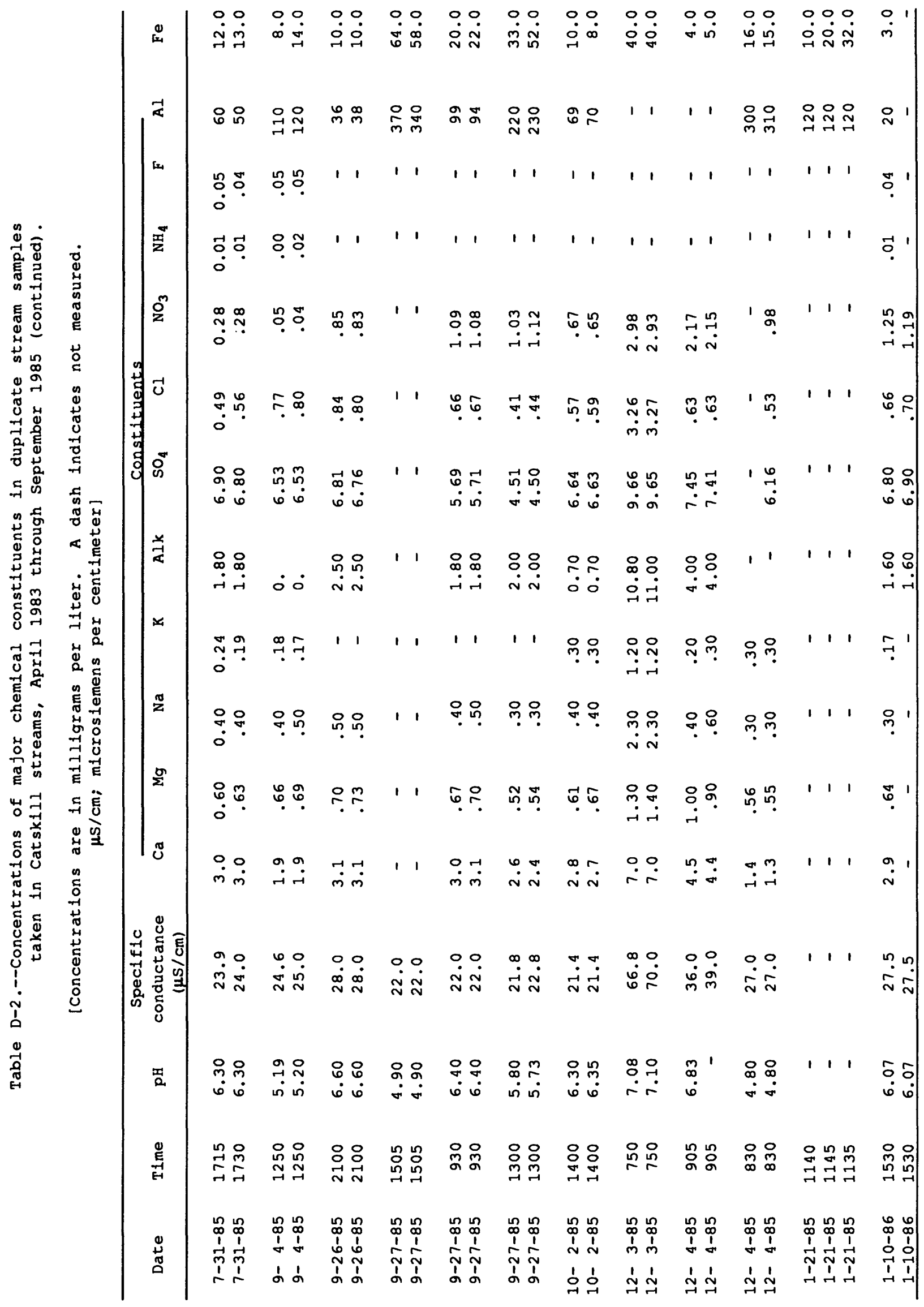


Table D-3.--Concentration of minor chemical constituents in duplicate samples taken in Catskill streams. April 1983 through January 1986

[Concentrations are in milligrams per liter, DOC = Dissolved organic carbon]

\begin{tabular}{|c|c|c|c|c|c|c|}
\hline \multirow{2}{*}{$\begin{array}{c}\text { Date } \\
\text { d-mo-yr }\end{array}$} & \multirow[b]{2}{*}{ Time } & \multicolumn{4}{|c|}{ Constituents } & \multirow{2}{*}{$\begin{array}{l}\text { Anion-to } \\
\text { cation } \\
\text { ratio }\end{array}$} \\
\hline & & Mn & Si & DOC & $\mathrm{PO}_{4}$ & \\
\hline $\begin{array}{l}4-10-83 \\
4-10-83\end{array}$ & $\begin{array}{l}1348 \\
1349\end{array}$ & $\begin{array}{r}27.00 \\
-\end{array}$ & $\begin{array}{l}1.5 \\
-\end{array}$ & $\begin{array}{r}5.9 \\
-\end{array}$ & $\begin{array}{r}0.00 \\
-\end{array}$ & $\begin{array}{r}0.99 \\
-\end{array}$ \\
\hline $\begin{array}{l}4-11-83 \\
4-11-83\end{array}$ & $\begin{array}{l}150 \\
151\end{array}$ & $\begin{array}{l}31.00 \\
27.00\end{array}$ & $\begin{array}{l}1.5 \\
1.2\end{array}$ & $\begin{array}{l}3.2 \\
4.8\end{array}$ & $\begin{array}{l}.00 \\
.00\end{array}$ & $\begin{array}{l}1.03 \\
0.66\end{array}$ \\
\hline $\begin{array}{l}4-11-83 \\
4-11-83\end{array}$ & $\begin{array}{l}410 \\
411\end{array}$ & $\begin{array}{l}29.00 \\
29.00\end{array}$ & $\begin{array}{l}1.4 \\
1.5\end{array}$ & $\begin{array}{l}4.1 \\
4.1\end{array}$ & $\begin{array}{l}.00 \\
.00\end{array}$ & $\begin{array}{l}0.91 \\
0.95\end{array}$ \\
\hline $\begin{array}{l}3-21-84 \\
3-21-83\end{array}$ & $\begin{array}{l}2115 \\
2115\end{array}$ & $\begin{array}{l}61.00 \\
62.00\end{array}$ & $\begin{array}{l}1.7 \\
1.7\end{array}$ & $\begin{array}{l}2.3 \\
2.2\end{array}$ & $\begin{array}{l}.00 \\
.00\end{array}$ & $\begin{array}{l}1.10 \\
1.11\end{array}$ \\
\hline $\begin{array}{l}4-5-84 \\
4-5-84\end{array}$ & $\begin{array}{r}33 \\
133\end{array}$ & $\begin{array}{l}8.00 \\
8.00\end{array}$ & $\begin{array}{l}1.5 \\
1.5\end{array}$ & $\begin{array}{l}1.6 \\
1.6\end{array}$ & $\begin{array}{l}.02 \\
.01\end{array}$ & $\begin{array}{l}0.98 \\
0.98\end{array}$ \\
\hline $\begin{array}{l}4-6-84 \\
4-6-84\end{array}$ & $\begin{array}{l}115 \\
116\end{array}$ & $\begin{array}{l}63.00 \\
63.00\end{array}$ & $\begin{array}{l}1.1 \\
1.1\end{array}$ & $\begin{array}{l}3.0 \\
3.1\end{array}$ & $\begin{array}{l}.00 \\
.06\end{array}$ & $\begin{array}{l}0.92 \\
1.01\end{array}$ \\
\hline $\begin{array}{l}9-12-84 \\
9-12-84 \\
9-12-84\end{array}$ & $\begin{array}{l}1000 \\
1000 \\
1001\end{array}$ & $\begin{array}{l}2.00 \\
2.00 \\
2.00\end{array}$ & $\begin{array}{l}2.3 \\
2.4 \\
2.3\end{array}$ & $\begin{array}{l}1.2 \\
1.0 \\
1.0\end{array}$ & $\begin{array}{l}.00 \\
.00 \\
.00\end{array}$ & $\begin{array}{l}0.90 \\
0.91 \\
0.90\end{array}$ \\
\hline $\begin{array}{l}11-5-84 \\
11-5-84\end{array}$ & $\begin{array}{l}850 \\
851\end{array}$ & $\begin{array}{l}7.00 \\
7.00\end{array}$ & $\begin{array}{l}1.9 \\
1.9\end{array}$ & $\begin{array}{l}4.2 \\
3.2\end{array}$ & $\begin{array}{l}.00 \\
.00\end{array}$ & $\begin{array}{l}0.92 \\
0.91\end{array}$ \\
\hline $\begin{array}{l}12-5-84 \\
12-5-84\end{array}$ & $\begin{array}{l}1555 \\
1556\end{array}$ & $\begin{array}{l}4.00 \\
3.00\end{array}$ & $\begin{array}{l}2.4 \\
2.3\end{array}$ & - & $\begin{array}{l}.00 \\
.00\end{array}$ & $\begin{array}{l}0.91 \\
0.91\end{array}$ \\
\hline $\begin{array}{l}2-12-85 \\
2-12-85\end{array}$ & $\begin{array}{l}1700 \\
1700\end{array}$ & $\begin{array}{l}1.00 \\
1.00\end{array}$ & $\begin{array}{l}3.0 \\
2.9\end{array}$ & $\begin{array}{l}4.7 \\
4.7\end{array}$ & $\begin{array}{l}.00 \\
.01\end{array}$ & $\begin{array}{l}1.00 \\
0.99\end{array}$ \\
\hline $\begin{array}{l}2-20-85 \\
2-20-85\end{array}$ & $\begin{array}{l}1645 \\
1645\end{array}$ & $\begin{array}{l}1.00 \\
2.00\end{array}$ & $\begin{array}{l}2.5 \\
2.5\end{array}$ & $\begin{array}{l}1.0 \\
1.0\end{array}$ & $\begin{array}{l}.00 \\
.00\end{array}$ & $\begin{array}{l}0.97 \\
0.94\end{array}$ \\
\hline $\begin{array}{l}3-1-85 \\
3-1-85\end{array}$ & $\begin{array}{l}1520 \\
1520\end{array}$ & - & - & - & - & - \\
\hline $\begin{array}{l}3-12-85 \\
3-12-85\end{array}$ & $\begin{array}{l}934 \\
935\end{array}$ & $\begin{array}{l}31.00 \\
32.00\end{array}$ & $\begin{array}{l}1.6 \\
1.6\end{array}$ & $\begin{array}{l}2.6 \\
2.6\end{array}$ & $\begin{array}{l}.00 \\
.00\end{array}$ & $\begin{array}{l}0.99 \\
0.99\end{array}$ \\
\hline $\begin{array}{l}3-13-85 \\
3-13-85\end{array}$ & $\begin{array}{l}1030 \\
1031\end{array}$ & $\begin{array}{l}23.00 \\
23.00\end{array}$ & $\begin{array}{l}1.8 \\
1.8\end{array}$ & $\begin{array}{l}1.6 \\
1.6\end{array}$ & $\begin{array}{l}.00 \\
.01\end{array}$ & $\begin{array}{l}0.97 \\
0.97\end{array}$ \\
\hline $\begin{array}{l}5-18-85 \\
5-18-85\end{array}$ & $\begin{array}{l}1715 \\
1715\end{array}$ & $\begin{array}{l}88.00 \\
88.00\end{array}$ & $\begin{array}{l}2.0 \\
2.0\end{array}$ & - & $\begin{array}{l}.00 \\
.00\end{array}$ & $\begin{array}{l}1.06 \\
1.05\end{array}$ \\
\hline $\begin{array}{l}12-3-85 \\
12-3-85 \\
12-3-85\end{array}$ & $\begin{array}{l}750 \\
750 \\
750\end{array}$ & $\begin{array}{l}11.00 \\
11.00 \\
11.00\end{array}$ & $\begin{array}{l}4.0 \\
4.0 \\
4.0\end{array}$ & - & - & - \\
\hline $\begin{array}{l}12-4-85 \\
12-4-85\end{array}$ & $\begin{array}{l}905 \\
905\end{array}$ & $\begin{array}{l}1.00 \\
1.00\end{array}$ & $\begin{array}{l}2.0 \\
2.0\end{array}$ & - & - & - \\
\hline $\begin{array}{l}12-4-85 \\
12-4-85\end{array}$ & $\begin{array}{l}830 \\
830\end{array}$ & $\begin{array}{l}69.00 \\
64.00\end{array}$ & $\begin{array}{l}2.1 \\
2.0\end{array}$ & $3 . \overline{0}$ & - & - \\
\hline $\begin{array}{l}1-21-85 \\
1-21-85 \\
1-21-85\end{array}$ & $\begin{array}{l}1140 \\
1145 \\
1135\end{array}$ & $\begin{array}{l}30.00 \\
20.00 \\
22.00\end{array}$ & $\begin{array}{l}1.8 \\
1.8 \\
1.9\end{array}$ & - & $\begin{array}{l}- \\
-\end{array}$ & - \\
\hline $\begin{array}{l}1-10-86 \\
1-10-86\end{array}$ & $\begin{array}{l}1530 \\
1530\end{array}$ & $\begin{array}{r}1.00 \\
-\end{array}$ & $\begin{array}{r}2.3 \\
-\end{array}$ & - & $\begin{array}{r}0.01 \\
-\end{array}$ & $\begin{array}{r}0.94 \\
-\end{array}$ \\
\hline
\end{tabular}


Table D-4.--Effect of storage time on field alkalinity and field $\mathrm{pH}$ measurements.

[A dash indicates not measured.]

A. FIELD ALKALINITY (in microequivalents per liter)

\begin{tabular}{|c|c|c|c|c|c|c|c|c|}
\hline \multirow[b]{2}{*}{ Date } & \multirow[b]{2}{*}{ Process } & \multirow[b]{2}{*}{ Initial } & \multicolumn{5}{|c|}{ Storage time (days) } & \multirow[b]{2}{*}{200} \\
\hline & & & 25 & 50 & 75 & 100 & 150 & \\
\hline $11-27-84$ & Raw & 32 & -- & -- & -- & 28 & -- & -- \\
\hline $2-23-85$ & Raw & 36 & -- & -- & -- & -- & -- & 36 \\
\hline $3-19-85$ & Raw & 20 & 20 & -- & -- & -- & 20 & -- \\
\hline $5-13-85$ & Raw & 32 & -- & -- & 30 & 32 & -- & -- \\
\hline $5-14-85$ & Raw & 32 & -- & -- & 30 & 32 & -- & -- \\
\hline $7-16-85$ & Raw & 28 & -- & 28 & -- & -- & -- & 28 \\
\hline $4-8-86$ & Raw & 30 & 32 & -- & 36 & 36 & -- & -- \\
\hline $4-8-86$ & Raw & 62 & 68 & -- & 70 & 64 & -- & -- \\
\hline $4-8-86$ & Filter & 112 & 114 & -- & 116 & 112 & -- & -- \\
\hline $4-8-86$ & Filter & 60 & 66 & -- & 62 & 64 & -- & -- \\
\hline
\end{tabular}

B. FIELD $\mathrm{pH}$ (in $\mathrm{pH}$ units)

\begin{tabular}{lllllll}
\hline & & \multicolumn{5}{c}{ Storage time } \\
\cline { 3 - 6 } Date & Process & Initial & 25 & 75 & 100 & 365 \\
\hline & & & & & & \\
$3-10-83$ & Raw & 6.03 & -- & -- & -- & 6.01 \\
$3-10-83$ & Raw & 6.21 & -- & -- & -- & 6.35 \\
$3-31-83$ & Raw & 6.20 & -- & -- & -- & 6.43 \\
$3-6-84$ & Raw & 5.07 & -- & -- & -- & 5.05 \\
$3-6-84$ & Raw & 6.12 & -- & -- & -- & 6.03 \\
$2-23-85$ & Raw & 6.39 & -- & -- & 6.40 & -- \\
$5-13-85$ & Raw & 6.28 & -- & 6.34 & 6.36 & -- \\
$7-16-85$ & Raw & 6.21 & 6.23 & -- & -- & -- \\
$4-8-86$ & Filtered & 6.94 & 7.09 & 7.08 & 7.14 & -- \\
$4-8-86$ & Raw & 6.47 & 6.41 & 6.54 & 6.59 & -- \\
$4-8-86$ & Filtered & 6.76 & 6.72 & 6.76 & 6.81 & -- \\
$4-8-86$ & Raw & 6.92 & 6.79 & 6.78 & 6.85 & -- \\
& & & & & & \\
\hline
\end{tabular}


Table D-5.--Comparison of $\mathrm{pH}$ and alkalinity measurements on raw and filtered high-flow samples containing suspended sediment.

[ $\mu$ eq $/ \mathrm{L}=$ microequivalents per 11ter]

\begin{tabular}{|c|c|c|c|c|}
\hline \multirow[b]{2}{*}{ Date } & \multicolumn{2}{|c|}{$\mathrm{pH}$ (units) } & \multicolumn{2}{|c|}{ 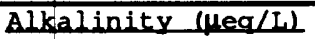 } \\
\hline & raw & filtered & raw & filtered \\
\hline $\begin{array}{l}4-5-84 \\
4-5-84 \\
2-18-86 \\
2-18-86 \\
5-1-86 \\
5-1-86 \\
5-1-86 \\
5-1-86 \\
5-2-86 \\
5-21-86\end{array}$ & $\begin{array}{l}5.09 \\
5.07 \\
6.66 \\
6.74 \\
6.36 \\
5.73 \\
4.99 \\
4.86 \\
6.97 \\
5.77\end{array}$ & $\begin{array}{l}5.07 \\
5.11 \\
6.80 \\
6.79 \\
6.43 \\
5.78 \\
4.93 \\
4.85 \\
6.91 \\
5.70\end{array}$ & $\begin{array}{r}0 \\
-6 \\
100 \\
84 \\
20 \\
12 \\
-8 \\
-16 \\
96 \\
10\end{array}$ & $\begin{array}{r}-4 \\
-2 \\
98 \\
84 \\
24 \\
8 \\
-12 \\
-14 \\
90 \\
12\end{array}$ \\
\hline
\end{tabular}

Table D-6.--Concentrations of major constituents and metals passed through $0.1-, 0.2-$, and $0.4-$ micrometer filters.

[Concentrations of major constituents are in microequivalents per liter. Concentrations of metals are in micrograms per liter. A dash indicates not measured.]

\begin{tabular}{|c|c|c|c|c|c|c|c|c|c|c|c|}
\hline \multirow[b]{2}{*}{ Aliquot } & \multirow[b]{2}{*}{ Size } & \multicolumn{7}{|c|}{ Major constituents } & \multicolumn{3}{|c|}{ Metals } \\
\hline & & $\mathrm{Ca}$ & Mg & $\mathrm{Na}$ & $\mathbf{K}$ & $\mathrm{SO}_{4}$ & $\mathrm{NO}_{3}$ & $\mathrm{Cl}$ & Al & $\mathrm{Fe}$ & Mn \\
\hline A & $\begin{array}{l}0.1 \\
0.2 \\
0.4\end{array}$ & $\begin{array}{l}165 \\
160 \\
165\end{array}$ & $\begin{array}{l}59 \\
56 \\
58\end{array}$ & $\begin{array}{l}22 \\
17 \\
17\end{array}$ & $\begin{array}{l}6.1 \\
5.9 \\
6.1\end{array}$ & $\begin{array}{l}146 \\
146 \\
148\end{array}$ & $\begin{array}{l}23 \\
23 \\
23\end{array}$ & $\begin{array}{l}7.2 \\
7.2 \\
7.2\end{array}$ & $\begin{array}{l}40 \\
30 \\
40\end{array}$ & $\begin{array}{l}3 \\
3 \\
3\end{array}$ & $\begin{array}{l}4 \\
4 \\
3\end{array}$ \\
\hline B & $\begin{array}{l}0.1 \\
0.2 \\
0.4\end{array}$ & $\begin{array}{l}294 \\
294 \\
294\end{array}$ & $\begin{array}{l}74 \\
74 \\
74\end{array}$ & $\begin{array}{l}35 \\
30 \\
30\end{array}$ & $\begin{array}{l}6.7 \\
6.7 \\
6.7\end{array}$ & $\begin{array}{l}160 \\
160 \\
158\end{array}$ & $\begin{array}{l}24 \\
25 \\
24\end{array}$ & $\begin{array}{l}12 \\
12 \\
12\end{array}$ & $\begin{array}{l}10 \\
10 \\
10\end{array}$ & $\begin{array}{l}3 \\
3 \\
3\end{array}$ & $\begin{array}{l}1 \\
1 \\
1\end{array}$ \\
\hline C & $\begin{array}{l}0.1 \\
0.2 \\
0.4\end{array}$ & $\begin{array}{l}274 \\
279 \\
279\end{array}$ & $\begin{array}{l}58 \\
58 \\
58\end{array}$ & $\begin{array}{l}17 \\
17 \\
17\end{array}$ & $\begin{array}{l}5.9 \\
5.9 \\
5.9\end{array}$ & $\begin{array}{l}154 \\
152 \\
152\end{array}$ & $\begin{array}{l}19 \\
19 \\
18\end{array}$ & $\begin{array}{l}6.6 \\
6.3 \\
6.3\end{array}$ & $\begin{array}{l}20 \\
10 \\
10\end{array}$ & $\begin{array}{l}4 \\
4 \\
3\end{array}$ & $\begin{array}{l}1 \\
2 \\
3\end{array}$ \\
\hline D & $\begin{array}{l}0.1 \\
0.2 \\
0.4\end{array}$ & $\begin{array}{l}70 \\
70 \\
70\end{array}$ & $\begin{array}{l}51 \\
51 \\
51\end{array}$ & $\begin{array}{l}16 \\
16 \\
15\end{array}$ & $\begin{array}{l}6.1 \\
6.1 \\
5.4\end{array}$ & $\begin{array}{l}131 \\
131 \\
133\end{array}$ & $\begin{array}{l}18 \\
18 \\
18\end{array}$ & $\begin{array}{l}6.3 \\
6.3 \\
6.3\end{array}$ & $\begin{array}{l}370 \\
390 \\
340\end{array}$ & $\begin{array}{l}12 \\
11 \\
12\end{array}$ & $\begin{array}{l}88 \\
88 \\
88\end{array}$ \\
\hline E & $\begin{array}{l}0.1 \\
0.2 \\
0.4\end{array}$ & $\begin{array}{l}155 \\
155 \\
150\end{array}$ & $\begin{array}{l}58 \\
60 \\
61\end{array}$ & $\begin{array}{l}22 \\
22 \\
22\end{array}$ & $\begin{array}{l}-- \\
-- \\
--\end{array}$ & $\begin{array}{r}140 \\
141 \\
139\end{array}$ & $\begin{array}{l}22 \\
23 \\
21\end{array}$ & $\begin{array}{l}14 \\
13 \\
13\end{array}$ & $\begin{array}{l}38 \\
38 \\
30\end{array}$ & $\begin{array}{l}-- \\
10 \\
3.0\end{array}$ & $\begin{array}{l}-\overline{0} \\
0.7 \\
2.0\end{array}$ \\
\hline $\mathbf{F}$ & $\begin{array}{l}0.1 \\
0.4\end{array}$ & -- & -- & -- & -- & $\begin{array}{l}100 \\
101\end{array}$ & $\begin{array}{l}25 \\
25\end{array}$ & $\begin{array}{r}9 \\
10\end{array}$ & $\begin{array}{l}340 \\
370\end{array}$ & $\begin{array}{l}58 \\
64\end{array}$ & $\begin{array}{r}99 \\
130\end{array}$ \\
\hline G & $\begin{array}{l}0.1 \\
0.2 \\
0.4\end{array}$ & $\begin{array}{l}65 \\
60 \\
65\end{array}$ & $\begin{array}{l}53 \\
49 \\
56\end{array}$ & $\begin{array}{l}17 \\
17 \\
17\end{array}$ & $\begin{array}{l}-- \\
-- \\
--\end{array}$ & $\begin{array}{l}-- \\
-- \\
--\end{array}$ & $\begin{array}{l}-- \\
-- \\
--\end{array}$ & $\begin{array}{l}-- \\
-- \\
--\end{array}$ & $\begin{array}{l}200 \\
210 \\
220\end{array}$ & $\begin{array}{r}12 \\
9 \\
12\end{array}$ & $\begin{array}{l}61 \\
60 \\
62\end{array}$ \\
\hline
\end{tabular}

